Boston University School of Law

Scholarly Commons at Boston University School of Law

Faculty Scholarship

Fall 2002

\title{
Convictions of Innocent Persons in Massachusetts: An Overview
}

Stanley Z. Fisher

Boston University School of Law

Follow this and additional works at: https://scholarship.law.bu.edu/faculty_scholarship

Part of the Criminal Law Commons, Criminal Procedure Commons, and the Evidence Commons

\section{Recommended Citation}

Stanley Z. Fisher, Convictions of Innocent Persons in Massachusetts: An Overview, 12 Boston University Public Interest Law Journal 1 (2002).

Available at: https://scholarship.law.bu.edu/faculty_scholarship/918

This Article is brought to you for free and open access by Scholarly Commons at Boston University School of Law. It has been accepted for inclusion in Faculty Scholarship by an authorized administrator of Scholarly Commons at Boston University School of Law. For more information, please contact lawlessa@bu.edu. 


\title{
ARTICLES
}

\section{CONVICTIONS OF INNOCENT PERSONS IN MASSACHUSETTS: AN OVERVIEW}

\author{
STANLEY Z. FISHER*
}

\section{INTRODUCTION}

The plight of innocent men and women in this country who have been convicted of serious crimes, incarcerated, and sometimes sentenced to death, has recently come dramatically to national ${ }^{1}$ and international ${ }^{2}$ attention. A rising tide

\footnotetext{
* Professor of Law, Boston University School of Law. I wish to acknowledge the helpful suggestions that I received on this project from Professors Richard A. Leo, Michael Meltsner, and Daniel Givelber, as well as valuable research assistance from Boston University School of Law students Jessica L. Fritz, Carolina Mirabel, and Summer L. Nastich. I also wish to thank Marlene Alderman, Raquel Ortiz, Dani Johansen, and other staff members of the B.U.S.L. Pappas Law Library for their consistently courteous and efficient responses to my requests for assistance. Finally, for their generous help, thanks to the members and staff of the New England Innocence Project and the Cardozo Innocence Project and to attorneys John Cavicchi, George L. Garfinkle, Victor Garo, Stephen Hrones, Peter Neufeld, Noah Rosmarin, Sam Silverman, Robert S. Sinsheimer, and Nona Walker.

1 See generally BARRY SCHECK ET AL., ACTUAL INNOCENCE (2000). The burgeoning literature includes scholarly, media, and judicial sources. Representative scholarly accounts include: EDWARD CONNORS ET AL., CONVICTED BY JURIES, EXONERATED BY SCIENCE: CASE STUdies IN THE USE OF DNA EVIDENCE TO ESTABlish INNOCENCE AFTER Trial (1996); Michael Radelet ET AL., IN SPITE OF INNOCENCE: ERRoneOUS Convictions IN Capital Cases (1992); Hugo Adam Bedau \& Michael L. Radelet, Miscarriages of Justice in Potentially Capital Cases, 40 STAN. L. REV. 21 (1987); Daniel Givelber, Meaningless Acquittals, Meaningful Convictions: Do We Reliably Acquit the Innocent?, 49 RUTGERS L. REV. 1317 (1997); Samuel R. Gross, Loss of Innocence: Eyewitness Identification and Proof of Guilt, 16 J. LEGAL STUD. 395 (1987) [hereinafter Gross, Loss]; Samuel R. Gross, The Risks of Death: Why Erroneous Convictions Are Common in Capital Cases, 44 BufF. L. REv. 469 (1996) [hereinafter Gross, Risks]; Michael L. Radelet et al., Prisoners Released from Death Rows Since 1970 Because of
} 
of prisoner exonerations, a significant number of which have relied upon DNA

Doubts About Their Guilt, 13 T.M. CoOLEY L. REv. 907 (1996).

For media accounts see Alan Berlow, The Wrong Man, ATLANTIC MonTHLY, Nov. 1999, at 66, available at http://www.theatlantic.com/issues/99nov/9911wrongman.htm; Ted Rohrlich, Scandal Shows Why Innocent Plead Guilty, L.A. TIMES, Dec. 31, 1999, at A1. Journalists with the Chicago Tribune have been especially prolific in examining and exposing miscarriages of justice. In January 1999, writers Ken Armstrong and Maurice Possley presented a series on prosecutorial misconduct in wrongful convictions cases in Illinois and other states. See Ken Armstrong, "True Patriot" Not Quite a Shining Star, CHI. TRIB., Jan. 9, 1999, and subsequent installments in the Chicago Tribune on January 10, 11, and 12. In November 1999, Armstrong and colleague Steve Mills examined 285 death-penalty cases in Illinois over the previous 22 years in a series entitled The Failure of the Death Penalty in Illinois. See Ken Armstrong \& Steve Mills, Death Row Justice Derailed, CHI. TRIB., Nov. 14, 1999 at 1, and subsequent installments in the Chicago Tribune on November 15, 16, 17, and 18. In December 2001, Armstrong, Mills, and Possley completed a four-part series entitled Cops and Confessions, on coerced confessions by police in Cook County, Illinois. See Ken Armstrong et al., Coercive and Illegal Tactics Torpedo Scores of Cook County Murder Cases, CHI. TRIB., Dec. 16, 2001, at 1, and subsequent installments in the Chicago Tribune on December 17, 18, and 19. Bill Moushey, of the Pittsburgh Post-Gazette, also wrote a ten-part series entitled Win at all Costs: Government Misconduct in the Name of Expedient Justice, discussing the misconduct of federal prosecutors in miscarriage of justice cases, in November and December of 1998. See Bill Moushey, Out of Control, Pittsburgh Post-GazetTe, Nov. 22, 1998, and subsequent installments on November 23, 24, 29, 30, and December 1, 6, 7,8 , and 13 .

For websites, see $A C L U$ Death Penalty Campaign, available at http://www.aclu.org/DeathPenalty/DeathPenaltyMain.cfm (last visited Jan. 22. 2003); Cardozo Innocence Project, available at http://www.innocenceproject.org (last visited Jan. 22, 2003); Northwestern University School of Law Center on Wrongful Convictions, available at http://www.law.northwestern.edu/wrongfulconvictions (last visited Jan. 22, 2003); Death Penalty Information Center, available at http://www.deathpenaltyinfo.org (last visited Jan. 22, 2003).

For noteworthy judicial opinions concerned with issues of factual innocence, see, e.g., Ring v. Arizona, 122 S. Ct. 2428 (2002) (Breyer, J., concurring); Herrera v. Collins, 506 U.S. 390 (1993); United States v. Quinones, 205 F. Supp. 2d 256 (S.D.N.Y. 2002), overruled by United States v. Quinones, 313 F.3d 49 (2d Cir. 2002).

${ }^{2}$ See, e.g., United States v. Burns, 2001 S.C.R. 7 (citing risk of executing innocent persons as grounds for invalidating defendant's extradition from Canada to United States without assurance that death penalty would not apply). See also Mohamed v. President of the RSA, 2001 (7) BCLR 685 (CC) (holding that it is illegal to deport and hand over to the United States a foreign suspect in bombing of United States Embassy in Tanzania without assurance that the suspect would not be subject to capital punishment); Bruce Shapiro, Dead Reckoning: A World Effort to Force an End to the US Death Penalty is Gaining Strength, THE NATION, Aug. 6, 2001, at 14 (discussing France's refusal to extradite James Charles Kopp, accused killer of Buffalo obstetrician Bernard Slepian, unless the death penalty was not "requested, pronounced, or applied"). 
testing, ${ }^{3}$ has revealed how miscarriages of justice can result from deficient practices of police interrogation and eyewitness identification, inadequate disclosure of exculpatory evidence, acceptance of unreliable "junk science" and "snitch" testimony, and ineffective assistance of counsel. ${ }^{4}$ Although most of the exonerations have taken place in death penalty states such as Illinois, Florida, Oklahoma, and Texas, ${ }^{5}$ non-death penalty states, including Massachusetts, have also exonerated prisoners and face a steady stream of new claimants. ${ }^{6}$

These developments suggest the timeliness of the present study, in which 1 attempt to list, and briefly describe, all known cases of wrongful convictions in Massachusetts courts since $1800 .^{7}$ My purpose is twofold. First, I hope to better inform the continuing debate over whether to reinstate the death penaity in Massachusetts. ${ }^{8}$ Advocates on both sides of the debate will presumably find

3 Between 1976 and August 2002, 102 death row prisoners in twenty states have been released on grounds relating to their factual innocence. Death Penalty Information Center, supra note 1 . To date, 114 prisoners nationwide have been exonerated by DNA testing and released. Cardozo Innocence Project, supra note 1. Since the first DNA exoneration in Massachusetts in 1997, six Massachusetts prisoners have been released as a result of exculpatory DNA testing. See infra Part III, Section A entries for Angel Hernandez, Neil Miller, Marvin Mitchell, and Eric Sarsfield; Part III, Section B entries for Rodriguez Charles and Kenneth Waters.

${ }^{4}$ See, e.g., RADELET ET AL., supra note 1; SCHECK ET AL., supra note 1; Bedau \& Radelet, supra note 1.

5 See Death Penalty Information Center, supra note 1. Illustratively, as of January 3, 2002, Florida had exonerated twenty-two death row prisoners, Illinois thirteen, Oklahoma seven, Texas seven, and Georgia six. Id. In 2000, after experiencing thirteen death row exonerations since 1975, Governor George H. Ryan of Illinois adopted a two-year moratorium on further executions. See Governor's Commission on Capital Punishment, available at http://www.idoc.state.il.us/ccp/ccp/reports/commission_reports.html (last visited Aug. 13, 2002). In January 2003, Governor Ryan pardoned four death row prisoners and commuted the death sentences of all of the remaining 163. See Editorial, The Error of Execution, Boston GLOBE, Jan. 13, 2003, at A18.

6 Some of these prisoners receive assistance from the New England Innocence Project ("N.E.I.P."). N.E.I.P. was established in 2000 by a group of Boston lawyers, law professors, and law students for the purpose of receiving, investigating, and litigating prisoner claims that DNA testing of biological evidence would establish their innocence. N.E.I.P. is part of the National Innocence Network founded by Barry Scheck and Peter Neufeld at Cardozo Law School. See Cardozo Innocence Project, supra note 1.

${ }^{7}$ I thus exclude the notorious seventeenth century Salem Witch Trials, in which twentyfour men and women "were hanged, crushed to death or died in prison." Last of Salem "Witches" Are Exonerated, NEWSDAY, Nov. 2, 2001, at A8. On November 1, 2001, Massachusetts Acting Governor Jane Swift signed legislation exonerating the last six victims who had not previously been exonerated. Id. Regarding the events in Salem see, e.g., Arthur Miller, The Crucible (1953) and Marion Lena Starkey, The Devil in MASSACHUSETTS: A MODERn INQUIRY INTO THE SALEM WITCH TRIALS (1949).

8 In 1997, a joint House and Senate bill to reinstate the death penalty in Massachusetts failed by a deadlocked tie vote. Brian Hauck et al., Capital Punishment Legislation in 
interest in the history of wrongful convictions in the Commonwealth. Second, I hope to shed light on the reasons why wrongful convictions in Massachusetts have occurred. Both individual case studies and studies of cases drawn from the entire country ${ }^{10}$ can reveal the general causes of "false positives" in the criminal justice system and suggest avenues of reform. Many of our most critical procedural practices, however, are governed by state law. This suggests the value of studying, in each jurisdiction, the lessons that known miscarriages can teach. ${ }^{11}$ In the present Article, I try only to identify the relevant cases and point out some of their most obvious implications for law reform. More detailed analysis and discussion of practices causally related to the conviction of innocent persons in Massachusetts must await further scholarship.

This Article draws upon previous works by others, chiefly Edwin Borchard, Michael Radelet, Hugo Bedau, and Constance Putnam, who, in national studies of erroneous convictions, cited and described a number of Massachusetts cases dating from the early-nineteenth century to the late-twentieth century!2 To their descriptions I have added other cases, mostly from recent years, which came to my attention from the media and other sources. When time and access to materials have permitted, I have attempted to corroborate and supplement secondary accounts by examining trial transcripts, appellate briefs and records, and judicial opinions.

Part II of this Article sets forth my criteria for identifying and classifying "innocence cases." In Part III, I divide the relevant Massachusetts cases (thirtythree in total) into three groups (tables), and discuss the cases in each group separately and alphabetically. Table A lists fifteen convicted persons who have been "officially" exonerated. Table B lists twelve convicted persons who have not been officially exonerated, but whose convictions have been reversed in circumstances raising strong doubts about their factual guilt. Table $\mathrm{C}$ lists six convicted persons who have won neither official exoneration nor freedom- all,

Massachusetts, 36 HARv. J. ON LEGIS. 479, $486-87$ (1999). On March 12, 2001, the Massachusetts House again rejected a bill to reinstate the death penalty. Steve Marantz, House Shoots Down Proposal to Bring Back Death Penalty, Boston Herald, Mar. 13, 2001, at 64. For other sources on the history of the death penalty in Massachusetts see infra note 174.

${ }^{9}$ See, e.g., the literature on the Sacco-Vanzetti case, infra note 235.

${ }^{10}$ See, e.g., supra note 1.

1 See Keith A. Findley, Learning from Our Mistakes: A Criminal Justice Commission to Study Wrongful Convictions, 38 CAL. W.L. REv. 333, 351 (2002) (advocating the formation in every jurisdiction of study commissions to "[draw] on the lessons from wrongful conviction cases within and outside their borders, and then to apply the lessons learned to the specific circumstances and conditions within their jurisdiction.").

12 See Edwin Borchard, CONVICTING the InNocent (1932) (describing, inter alia, seven erroneous convictions in Massachusetts between 1885 and 1928); RADELET ET AL., supra note 1 (describing, inter alia, twelve erroneous convictions in Massachusetts capital cases between 1900 and 1991). The latter work expanded upon Bedau \& Radelet, supra note 1, at 103-04. See also Radelet et al., supra note 1. 
indeed, were executed or died in prison - but as to whom strong, credible claims of factual innocence exist. In Part IV, I analyze and comment upon this data and draw conclusions about its implications for law reform in the Commonwealth. Part V consists of a brief conclusion.

\section{WHO ARE THE "INNOCENT"?}

Although one could define "innocent" persons more broadly, I restrict the concept to those who are "factually innocent" in the sense that they were not involved "physically or legally" in the crime. ${ }^{13}$ In adopting this restriction, I follow a well-established, conservative approach. ${ }^{14} \mathrm{I}$ include only cases in which an innocent person was convicted, ${ }^{15}$ thus excluding cases of wrongful arrest, charge, detention, and trial where the charges were dismissed or the defendant was acquitted. ${ }^{16}$ Although a study of such "inchoate" miscarriages of justice might produce important insights into the fairness and efficacy of our criminal justice system, ${ }^{17}$ it seems wise to concentrate on the smaller, more visible number of cases in which innocent persons were convicted. ${ }^{18}$ Some of those persons were

13 A "factually innocent" person is one who did not commit the actus reus of the crime, either himself or through another for whose conduct he was responsible as an accomplice. Thus, the category "wrongfully convicted" excludes a convicted person who was "legally" innocent because he lacked the required mens rea, had a good defense of excuse (e.g., insanity, duress) or justification (e.g., self-defense, necessity), was denied a fair trial, or was convicted in violation of some other specific substantive or procedural right.

14 See Paul Cassell, The Guilty and the 'Innocent:' An Examination of Alleged Cases of Wrongful Conviction from False Confessions, 22 HARV. J.L. \& PUB. POL'Y 523, 535-36 and n.47 (1999) (citing scholarship adopting the narrow focus on "factual innocence").

15 Thus, I exclude the case of Christina Hill, who was convicted of armed robbery and murder at a bench trial under the de novo system. At Hill's de novo jury trial, apparently on the same evidence, she was found not guilty. Hill should not be considered to have been "convicted" because under the de novo system, her appeal for a trial de novo had the effect of nullifying her first trial conviction. Compare RADELET ET AL., supra note 1, at 314 (counting Hill among the wrongfully convicted).

${ }_{16}$ See, e.g., Bedau \& Radelet, supra note 1, at $44-45$ (discussing the wrongful prosecution of Louis Berrett and Clement Molway in Massachusetts in 1934). Eight eyewitnesses identified Berrett and Molway as the men who murdered the victim. Id. at 44. "Just prior to the final arguments at their trial, the actual killers confessed." Id.

17 See, e.g., ConNORS ET AL., supra note 1 (writing that between 1989 and 1996, forensic DNA testing in sexual assault cases has excluded the primary suspect in twentyfive percent of cases where results could be obtained). Since most of these cases involved mistaken identifications, the high pretrial exoneration rate suggests the need to evaluate current eyewitness identification procedures and rules.

18 Of course, "mere" investigation and prosecution of an innocent person can cause serious, even irreparable, harm. See, e.g., Stanley Z. Fisher, Just the Facts, Ma'am: Lying and the Omission of Exculpatory Evidence in Police Reports, 28 NEW ENG. L. REV. $1,32-40$ (1993) (describing harm to defendants from omission of exculpatory evidence in 
exonerated or released on direct appeal $;{ }^{19}$ others failed to win on appeal, but won relief, if at all, on motions for new trial or through executive pardon. ${ }^{20}$

Having defined "the innocent" as convicted, factually innocent persons, we confront the question of how to distinguish factually innocent convicts from factually guilty ones. This is no simple task. As Professor Daniel Givelber has noted, "[c]ourts virtually never address or rule upon the question of whether the defendant is truly innocent. Instead, judges and juries determine that a defendant is 'not guilty' or that a guilty verdict was infected by legal error and must be reversed." 21 The lack of any official mechanism ${ }^{22}$ for deciding claims of factual innocence, as opposed to guilt, makes it difficult to establish the negative proposition that a person did not commit the crime for which he was convicted.

Scholars disagree about the proper criteria for classifying any particular convicted person as "factually innocent." In their groundbreaking 1987 article listing 350 erroneous convictions in potentially capital cases, criminologists Hugo Bedau and Michael Radelet were the first to propose criteria for systematically categorizing cases of wrongfully convicted, factually innocent persons. ${ }^{23}$ They conceded that only in rare cases is it possible to "definitively prove innocence;" usually, "[t]he most one can hope to obtain is a consensus [as to innocence] of investigators. "24 Consequently, they counted as miscarriages cases in which they believed that "a majority of neutral observers, given the evidence at our disposal, would judge the defendant ... to be innocent." ${ }^{25}$ In applying this admittedly

police reports). See also April Witt, Allegations of Abuses Mar Murder Cases, WASH. Post, June 3, 2001, at A1; April Witt, The Killer Bled, WASH. POST, June 6, 2001, at A1 (reporting on DNA exonerations of Keith Longtin and Aaron Wright, who were jailed for eight and seven months, respectively, after police claimed they confessed to murders). But conviction compounds the harm and signifies a greater failure of the system's safeguards. While many of the same flaws in the system that lead to aborted prosecutions of innocent persons will come to light in a study of prosecutions that culminate in conviction, fuller and more accurate data will likely be available for the latter class of cases than for the former. This data, which includes trial and motion transcripts, appellate briefs, and appellate opinions, lends greater authority and credence to a judgment that the defendant was factually innocent.

19 See, e.g., cases of Ella Mae Ellison and Peter Vaughn, infra Part III, Section B.

${ }^{20}$ See, e.g., cases of John Chance and Cornelius Usher, infra Part III, Section A.

${ }^{21}$ Givelber, supra note 1, at 1322-23.

${ }^{22}$ Although a governor in granting a pardon might declare the convicted person's factual innocence, the pardon per se does not imply such a finding. See Mass. Gen. Laws ch. 127, § 154 (2002) (pardon board is prohibited from considering guilt or innocence); United States v. Wilson, 32 U.S. 150, 160 (1833) ("A pardon is an act of grace . . which exempts the individual, on whom it is bestowed, from the punishment the law inflicts for a crime he has committed.").

${ }^{23}$ Bedau \& Radelet, supra note 1, at 47. Bedau and Radelet later expanded their list of 350 cases in RADELET ET AL., supra note 1, and Radelet et al., supra note 1.

${ }^{24}$ Bedau \& Radelet, supra note 1, at 47.

25 Id. 
subjective standard, Bedau and Radelet characterized their 350 listed cases as forming a continuum, "from those where the evidence for innocence is conclusive to those where the evidence is slight." ${ }^{26}$ The cases they classified as miscarriages fell into two main categories: (1) where "decisions by actors in the criminal justice system or in one of the branches of state government may indicate a belief that the conviction was in error;" and (2) where "indications from others not acting in any official role ... may point to an erroneous conviction." 27 Strong, but neither necessary nor sufficient evidence of official actions in the authors' first category include prosecutorial acknowledgements of error, legislative grants of indemnity, executive pardon, commutation, or parole ${ }^{28}$ The authors also treat judicial reversal of a conviction as "a significant indication of serious error either when the defendant is acquitted following retrial or when the indictment is dismissed (under an entry of nolle prosequi). ${ }^{29}$ However, they consider acquittal or dismissal significant only "when it is based on incontrovertible evidence that no crime occurred or on other strong evidence that the defendant was indeed innocent." 30

Bedau and Radelet's broad "neutral observer" standard" has been criticized as

${ }^{26}$ Id. at 48 .

${ }^{27}$ Id. Eighty-eight percent of the authors' 350 cases fell into the first category. Id. at 49.

28 See id. at 50-51.

29 Bedau \& Radelet, supra note 1 , at 51 .

${ }^{30}$ Id. at 47 . Compare the broader criteria that the Death Penalty Information Center uses in listing forty-three innocence cases, which include persons who were "released from prison after serving time on death row . . . with significant evidence of their innocence. In these cases, the defendant was subsequently acquitted, pardoned, or charges were dropped." In five additional cases, broader criteria were used. Email from Paula Bernstein, DPIC Information Specialist (Sept. 26, 2002) (on file with author).

31 Compare the approach of Professors Richard Leo and Richard Ofshe, whose scholarship on false confessions by innocent persons sparked a vigorous debate, with Professor Paul Cassell. Leo and Ofshe identified 60 cases in which they concluded that an innocent person had falsely confessed. They classified the cases as involving "proven," "highly probable," and "probable" false confessions. In the authors' view, in none of these cases was there physical or other "significant and credible evidence" indicating the suspect's guilt. See Richard A. Leo and Richard J. Ofshe, The Consequences of False Confessions: Deprivations of Liberty and Miscarriages of Justice in the Age of Psychological Interrogation, 88 J. CRIM. L. \& CRIMINOLOGY 429, 436-37 (1998). Leo and Ofshe's criteria are subjective in the sense that observers can differ as to whether evidence of guilt in a particular case is "significant and credible."

Entries in the debate between Leo and Ofshe and Paul Cassell include Cassell, supra note 14; Cassell, Protecting the Innocent from False Confessions and Lost Confessions and from Miranda, 88 J. CRIM. L. \& CRIMINOLOGY 497 (1998); Richard A. Leo \& Richard J. Ofshe, Using the Innocent to Scapegoat Miranda: Another Reply to Paul Cassell, 88 J. CRIM. L. \& CRIMINOLOGY 557 (1998); Richard Leo \& Richard Ofshe, The Truth About False Confessions and Advocacy Scholarship, 37 CRIM. L. BULL. 293 (2001). 
"overly subjective" and "one sided." 32 In contrast, Professor Samuel Gross, in studying 136 cases of mistaken identification, used a narrower, allegedly more objective $^{33}$ test that employs what might be termed a standard of "official exoneration." ${ }^{34}$ Professor Gross chose to examine only cases in which the accused's factual innocence was "undisputed," as evidenced by official endorsement of that fact. ${ }^{35}$

For the purpose of understanding the causes of erroneous convictions and bringing about needed reforms, the study of cases in which innocent persons have been officially exonerated offers exceptional promise. In comparison to cases where authorities dispute the convicted person's innocence, the fact of official exoneration is more likely to persuade key criminal justice constituencies, including police, prosecutors, judges, and legislators, that a problem exists for which solutions must be found. ${ }^{36}$ In this way, official exoneration cases can be used to legitimate law reform efforts and enlist support from influential segments of the body politic.

However, confining our attention to cases of "undisputed innocence" is problematic for two reasons. First, it gives undue weight to the judgments of executive officials and would result in the exclusion of cases that most observers would regard as miscarriages of justice. Second, direct evidence of official belief in an accused's factual innocence is often lacking. In a number of cases, the observer can reasonably infer the existence of that belief from surrounding circumstances. Doing so, however, introduces an additional subjective element into application of the "undisputed" category. I will discuss these two points in order.

\section{A. Unjustified Reliance Upon Executive Judgments on Innocence}

As defined by Professor Gross, the "undisputed innocence" test is satisfied only if (1) a judicial or (2) executive authority "determines" that the accused is

32 Stephen J. Marksman \& Paul G. Cassell, Protecting the Innocent: A Response to the Bedau-Radelet Study, 41 STAN. L. REV. 121, 122, 126-28 (1988). Bedau and Radelet responded to the Markman-Cassell critique in Hugo Bedau \& Michael Radelet, The Myth of Infallibility: A Reply to Markman and Cassell, 41 STAN. L. REV. 161 (1988). When Professor Cassell published his critique of the Bedau-Radelet study, he and his co-author, Stephen Markman, were both employed by the United States Department of Justice.

${ }^{33}$ But see infra text accompanying notes 37-52.

34 See Gross, Loss, supra note 1, at 412 (analyzing 136 mistaken identification cases, including cases ending in dismissals and acquittals, as well as convictions, between 1900 and 1983). See also Cassell, supra note 14, at 581 (expressing preference for Gross' test over the Bedau-Radelet test).

35 See Gross, Loss, supra note 1 , at 412.

36 Thus, the death penalty moratorium movement has been fueled by the spate of death row exonerations in Illinois, Florida, and other states. See, e.g., Jeffrey L. Kirchmeier, Another Place Beyond Here: The Death Penalty Moratorium Movement in the United States, 73 U. Colo. L. Rev. 1, 39-43 (2002). 
factually innocent, or (3) the original "prosecuting authority" expresses that belief. ${ }^{37}$ In practice, the first condition will rarely, if ever, occur. As indicated above, ${ }^{38}$ courts rarely have any occasion for passing upon, much less affirmatively "determining," an accused person's factual innocence ${ }^{39}$ Almost exclusively, therefore, official exoneration will depend upon the decisions of executive pardon authorities and of the district attorney's office that originally prosecuted the case. These officials will typically decide the convict's factual innocence by assessing the significance and credibility of newly discovered evidence, a process that allows, if it does not invite, the play of personal and political biases. Thus, Joseph Salvati's failure to win exoneration from pardon authorities was influenced by the FBI's own misguided agenda ${ }^{40}$ Similarly, efforts to obtain posthumous pardons for two executed men were apparently defeated by Governor King's reluctance to appear weak on the issue of capital punishment in a re-election year. ${ }^{41}$ Therefore, although the "undisputed innocence" test offers an externally "objective" criterion, its application turns ultimately on personal, and possibly arbitrary, judgments by executive officials.

Furthermore, by counting only innocence determinations made by judicial or executive authorities, Professor Gross apparently intends to exclude legislative determinations. Presumably, therefore, Bobby Joe Leaster, who was exonerated

37 See Gross, Loss, supra note 1, at 412 . Professor Gross specifically excludes cases in which a convicted person plausibly claims innocence, as well as cases "in which, without more, the defendant was acquitted by a judge or jury or in which his conviction was reversed by an appellate court for insufficient evidence of identity . . ." Id. Like Paul Cassell, Samuel Gross is a law professor. Legal academics writing about miscarriages have tended to adopt narrower criteria for identifying factually innocent convicts than scholars who identify themselves primarily as sociologists, such as Professors Bedau, Radelet, and Leo. For a view of miscarriages as a product of tension between the legal system's attachment to due process and the media's attachment to truth, see RICHARD NOBLES \& DAVID SCHIFF, UNDERSTANDING MisCARRIAGES OF JUSTICE (2000).

38 See supra text accompanying note 21.

39 As Professor Gross points out, "[a]cquittals and reversals are not usually based on affirmative findings of innocence but rather on deficient evidence of guilt . . .." Gross, Loss, supra note 1, at 412. Because Professor Gross does not indicate which type of official action amounted to exoneration for each of his 136 cases, one cannot know how many involved judicial determinations of innocence. In one case, the acquitting jury returned a verdict declaring: "We, the jury, being convinced that the prisoner at the bar is Payne Boyd and not Cleveland Boyd, find him not guilty . . . B" BORCHARD, supra note 12, at 27 (citing West Virginia v. Boyd, 280 S.E.2d 669 (W. Va. 1981) (record in the office of the Clerk of the Circuit Court, Cabell County, W.Va., containing a 411-page transcript of the trial testimony). Presumably, this was a rarity, because juries in criminal cases are normally limited to returning return general verdicts of "guilty" or "not guilty."

40 See infra text accompanying note 181.

41 See 176 Years Late? Gubernatorial Pardon Being Sought in 19th Century Murder Case Here, DaILY HAMPSHIRE GAZETTE, June 10, 1982, at 3. See also the Harding and Leaster cases, infra text accompanying notes 128 and 148. 
only by the Massachusetts legislature, ${ }^{42}$ would not count as indisputably innocent. On the rare occasion $s^{43}$ when such legislative declarations occur, should they not "count?" At first blush, we might consider prosecutors and pardon officials better qualified than legislators to make reliable judgments about factual innocence. Those executive agencies can draw not only on the public record of proceedings against the accused, but also on information which, although reliable, might lie outside the record. Such information might exist in confidential records of past and current investigations, statements of confidential informants, and grand jury minutes. Furthermore, prosecutors and executive pardon officials are well-positioned to draw directly upon the informed views of specialized personnel, whose professional motivation and skills qualify them to interpret the relevant data accurately. Legislative decision makers, in contrast, might lack both ready access to the relevant data and the expertise to evaluate it properly. Legislators also differ from prosecutors and pardon officials in having a broader, more diffuse political mandate, one that is less focused upon law enforcement and crime control. Therefore, one might fear that their innocence judgments might respond more to political pressure than to the merits of the claim.

Notwithstanding the foregoing, a persuasive argument can be made that legislative declarations of innocence should "count." Although legislators lack the law enforcement background and expertise of prosecutors and police, they normally hear and listen respectfully to the voices of those constituents. To the extent that legislators have a smaller psychological and political stake than executive officials in suppressing errors and abuses committed by law enforcement, they are more objective. Although political pressures operate on legislators, just as they do on district attorneys and pardon authorities, legislators on the whole respond to a wider set of interests than do executive agents. ${ }^{44}$ As representatives of the community at large, legislators are most likely to take an interest in exonerating convicted persons in particularly egregious cases. ${ }^{45}$ In such cases, their broad democratic base frees them to correct perceived injustices

42 See infra text accompanying note 155 . Cornelius Usher, too, was declared innocent by the Legislature. However, the District Attorney supported Usher's pardon application, from which I have inferred the former's belief in Usher's innocence and thereby classified his exoneration as "undisputed."

${ }^{43}$ In the sample of thirty-three innocence cases identified in this Article, only the Leaster and Usher cases involved legislative declarations of innocence.

44 See William Eskridge et al., Cases and Materials on legislation: Statutes And the CReation of Public Policy 49 (3d ed. 2001) (in a decentralized pluralist system, the legislature responds to a broad range of interest groups in checking ambitions of government actors).

45 The Massachusetts' legislature has generally refrained from taking an active role in prisoner exonerations. See, e.g., infra text accompanying notes 311-14 (noting its reluctance over the years to grant compensation to exonerated prisoners). See also infra text accompanying notes $259-60$ (noting legislative criticism of gubernatorial proclamation absolving Sacco and Vanzetti of "stigma and disgrace"). 
that the executive authorities will not remedy. ${ }^{46}$ Thus, the legislature can provide a valuable check on the executive branch when the latter withholds a deserved declaration of factual innocence.

In this Article, I seek to identify Massachusetts cases in which the convicted person's factual innocence is "undisputed," as defined by Professor Gross (Table A). However, for reasons discussed immediately below, I often base that categorization on inference rather than direct evidence. After identifying those cases, I go further by also considering, separately, cases in which no executive or judicial exoneration has occurred. My criterion for selecting those cases is whether strong reasons exist to believe in the convicted person's factual innocence. I divide those cases into two groups: persons whose convictions have been reversed under circumstances raising strong doubts about their factual guilt (Table B) and other convicted persons as to whom strong, credible claims of factual innocence exist (Table $C$ ). These criteria are admittedly subjective in the sense that they call for a private judgment as to the convicted person's factual innocence. In order to mitigate this subjectivity, I have taken several steps. First, I have attempted to learn the facts and evidence in each case by consulting original, as well as secondary, case documents. Second, I have tried, where feasible ${ }^{47}$ to describe the main evidence supporting, as well as opposing, the prisoner's guilt. Finally, I have cited the principal sources upon which my knowledge is based. I hope that these precautions will assist interested readers to reach their own, independent conclusions.

\section{B. Evidence of Official "Determinations" or "Beliefs" in Actual Innocence}

Professor Gross' criterion of "undisputed" innocence is satisfied only if a competent official "determines" or "expresses the belief" that the accused is factually innocent. ${ }^{48}$ Externally, this test appears to avoid the subjectivity inherent in Bedau and Radelet's broad "neutral observer" standard. Frequently, however, even in cases whose circumstances strongly imply such a determination or belief, we lack direct evidence of it. ${ }^{49}$ Thus, in only five of the Table A cases

${ }^{46}$ Furthermore, the legislature can use its investigative powers, including witness subpoenas, to inform its decision on a claim of innocence. The United States Congress' investigation into the Salvati Four case is a prime example of this phenomenon. See infra text accompanying notes 189-90.

${ }^{47}$ My research for this Article sharpened my appreciation of the difficulty of locating and mastering the "facts" underlying many of the cases under study. Commonly, the relevant "facts" are both highly complex and seriously in dispute. Also, the constraints of time and other resources severely limited my ability to gather and digest these facts, even those pertaining to a single case. Finally, an attempt to write about a fairly large number of cases, in a narrative of moderate length, competed against the desire to present a complete and balanced account of the evidence in each case.

${ }_{48}$ See supra text accompanying note 1.

${ }^{49}$ Whenever possible, I sought this information in the text of the prosecutor's nolle prosequi. However, I did not often have access to that document. This forced me, 
did I find explicit evidence of the relevant authority's belief in the convicted person's innocence. ${ }^{50}$ In the other ten Table A cases, the relevant authority's ${ }^{51}$ "determination" of factual innocence was only implicit. In those cases, I inferred that the relevant authority endorsed the accused's factual innocence from such official conduct as (1) initiating or supporting the convict's motion for new trial or his pardon application; (2) making comments that imply, rather than state, a belief in innocence; (3) apologizing to the convict; (4) in a single perpetrator case, successfully prosecuting another person after dismissing charges against the convict; (5) after exculpatory DNA testing in a single perpetrator case, dismissing the charges against the convict without making statements that imply the absence of that belief. In another case, ${ }^{52}$ I inferred a belief in innocence on the part of the governor who pardoned the convict. He did so with the support of the former trial judge after an investigation reportedly corroborated another man's confession to the crime.

One might criticize using judgment and inference to classify such cases as "official exonerations." Undoubtedly, the objectivity of the "undisputed innocence" category would be better served by excluding cases in which we lacked direct evidence of an official finding of factual innocence. However, that would further narrow the scope of the "undisputed innocence" category. As a result, we would exclude still more exonerations of prisoners who, in the eyes of most if not all cautious observers, were factually innocent.

\section{Innocent Persons Who Have BeEn Convicted in Massachusetts}

This Part describes three categories of innocent persons who have been convicted in Massachusetts. In Table A, I list and describe cases in which convicted persons have been "officially exonerated." In subsequent Sections, I list and describe Tables B and C cases.

\section{A. Official Exonerations}

In Table A, below, I list fifteen Massachusetts prisoners whose factual innocence I consider "undisputed" according to Professor Gross' criteria. In five of these cases, I found direct, explicit evidence of a relevant official's belief in the prisoner's factual innocence. In the remaining ten cases, I inferred that belief from surrounding circumstances. Interestingly, only four of the six Massachusetts DNA "exonerations" were "undisputed. ${ }^{\text {"3 }}$

therefore, to rely on media reports.

${ }^{50}$ See infra Table 4, the cases of Hernandez, McManus, Mitchell, Passley, and Sarsfield.

51 In all but two Table A cases, this was the original prosecuting agency.

52 See the case of John Chance, infra text accompanying note 62 .

53 Prosecutors explicitly declared Mitchell's and Sarsfield's innocence and apologized to Hernandez. Although I have inferred the prosecution's acceptance of Miller's innocence, I 
Table A

Officially Exonerated Persons Whose Factual Innocence Is "Undisputed"

\begin{tabular}{|c|c|c|c|c|c|c|}
\hline Name & Convicted & Releasec & Crime $^{54}$ & $\begin{array}{c}\text { Years } \\
\text { Incarcerated }\end{array}$ & $\mathrm{DNA}$ & Compensation \\
\hline Andrews & 1914 & 1914 & Utteringss & $4 \mathrm{mos}$. & - & - \\
\hline Chance & 1898 & 1911 & Murder I & 12 & - & Bill failed \\
\hline Chesterman & 1886 & 1886 & Larceny & $2 \mathrm{wks}$ & - & - \\
\hline Collins & 1928 & 1928 & Robbery & $2 \mathrm{mos}$. & - & Bill failed \\
\hline Hernandez & 1988 & 2001 & Rape & 14 & Yes & - \\
\hline Johnson & 1996 & 1999 & Murder I & 5 & - & $\begin{array}{l}\text { Civil suit } \\
\text { pending }\end{array}$ \\
\hline McManus & 1911 & 1912 & Larceny & $11 \mathrm{mos}$. & - & \\
\hline Miller & 1990 & 2000 & Rape & 10 & Yes & Bill pending \\
\hline Mitchell & 1990 & 1997 & Rape & 7 & Yes & Yes ${ }^{56}$ \\
\hline O'Connell & 1935 & 1935 & $\begin{array}{c}\text { Sexual } \\
\text { Assault }\end{array}$ & $1 \mathrm{mo}$. & - & - \\
\hline Passley & 1996 & 2000 & Murder I & 4 & - & \\
\hline Rodriquez & 1954 & 1957 & $\begin{array}{c}\text { Murder } \\
\text { II }\end{array}$ & 3 & - & $Y{ }^{57}$ \\
\hline Sarsfield & 1987 & 1999 & Rape & 9 & Yes & \\
\hline Usher & 1902 & 1904 & B\&E & 2 & - & $\mathrm{Yes}^{58}$ \\
\hline Ward & 1895 & 1896 & $\begin{array}{c}\text { Larceny } \\
(?)\end{array}$ & 8 mos. & - & - \\
\hline
\end{tabular}

\section{Herbert T. Andrews, Suffolk County ${ }^{59}$}

After coming to the attention of police because he overdrew his bank account, Andrews was charged with forging and uttering over forty checks. He had no criminal record. Seventeen witnesses identified him at trial as the man who had

found no evidence of any explicit acknowledgment. By contrast, in both the Charles and Waters cases, infra Table B, prosecutors explicitly refused to acknowledge the prisoner's factual innocence.

54 Most serious crime for which defendant was convicted.

ss "Uttering" refers to the crime of passing a forged check or other instrument. See MASS. GEN. LAWS. ch. 267, $§ 5$ (2000).

56 Won civil suit settlement.

57 Private bill.

58 Private bill.

59 See BoRCHARD, supra note 12, at 1-7; Barnes Gets 18-Months Term, Boston Globe, June 19, 1914, at 10; Case of Mistaken Identity, Boston GlOBE, June 15, 1914, at 14; Earl Barnes Arrested, Boston GloBE, June 13, 1914, at 2; Thomas D. Lavelle, When Seeing is Not Believing, BOSTON GLOBE, July 24, 1932, at 18 . Lavelle was the former Assistant District Attorney of Suffolk County, Massachusetts. 
passed fraudulent checks to them. On February 26, 1914, he was convicted of seventeen counts of uttering bad checks and sentenced to fourteen months in jail. Fortunately for Andrews, while he was imprisoned awaiting trial, bad checks, similar to those for which he had been convicted, continued to be passed in the Boston area. Police found the perpetrator, Earle Barnes, who confessed to forging and passing many of the checks for which Andrews had been convicted. When police informed the prosecutor of this, he agreed to a new trial motion and nol prossed the indictment. According to the trial prosecutor, writing afterwards about the case, Andrews and the actual perpetrator "were as dissimilar in appearance as could be. There was several inches difference in height and there wasn't a similarity about them. To this day I can't understand the positiveness of those [identification] witnesses." 60 Photographs of the two men's faces, published in the newspaper, confirm this dissimilarity. ${ }^{61}$ Andrews spent about four months in jail before he was freed.

\section{John H. Chance, Suffolk County ${ }^{62}$}

In April 1898, a Boston drug store was robbed and the clerk killed. Chance was identified as the owner of a coat found near the scene that resembled the coat reportedly worn by the perpetrator. Chance and a co-defendant, Arthur Hagan, were tried for murder. Chance testified on his own behalf but was impeached by prior inconsistent statements. A jury convicted Chance and acquitted Hagan. Chance received a life sentence, which he unsuccessfully appealed. In 1905, Chance notified the Governor that Hagan, then living in Chicago, had confessed to committing the crime by himself. It took nearly six years for the authorities to investigate this claim. In return for immunity from re-prosecution, Hagan affirmed that he alone was involved in the robbery-murder and that Chance was innocent. Further investigation corroborated the truth of Hagan's confession. Statements were submitted in support of Chance's innocence by both Hagan's lawyer and the trial judge. On June 7, 1911, the Governor pardoned Chance after he had served nearly twelve years in prison. A bill awarding compensation to Chance failed to pass in the legislature.

As Professor Borchard has written: "Chance's case arouses no special sympathy. He contributed to his misfortune by telling crucial falsehoods in court. It seems that he was much under the influence of Hagan and tried to shield him, believing that he himself was in no danger of conviction. ${ }^{163}$

${ }^{60}$ Lavelle, supra note 59.

${ }^{61}$ See Andrews, Innocent, Freed From Prison, Boston Globe, June 13, 1914, at 1.

62 See BoRCHARD, supra note 12, at 332-37; Commonwealth v. Chance, 174 Mass. 245 (1899); Innocent After 11 Years in Prison, Boston Dally Globe, June 8, 1911, at 1.

${ }^{63}$ BORCHARD, supra note 12 , at 337. 


\section{John Chesterman, alias John Christman, Worcester County ${ }^{64}$}

In the fall of 1885 , in the Worcester area, Charles Vokes called the police, claiming to have caught his former employee, John Chesterman, stealing from his house. When police responded, Chesterman was gone, but Vokes showed them his (Vokes') personal property strewn about the floor. Police later caught Chesterman and charged him with larceny. Primarily on the basis of Vokes' testimony, the jury convicted Chesterman. The judge sentenced him to a year in jail. A few weeks later, Vokes approached the authorities to confess that he had falsely accused Chesterman and committed perjury at the trial. In truth, Chesterman had come to Vokes' house seeking payment of back wages. To avoid paying, Vokes ran him off and staged the "larceny." On the basis of Vokes' confession, the prosecutor obtained the Governor's pardon for Chesterman. Chesterman was freed on February 12, 1886. Vokes was subsequently prosecuted for perjury.

\section{Benjamin Collins, Middlesex County ${ }^{65}$}

Collins was arrested on September 1, 1928, for committing a series of handbag snatches in Somerville. When arrested, he had none of the stolen property either on his person or in his home. Furthermore, he was employed and had no criminal record. Although the investigating police officer doubted his guilt, five of the victims positively identified him as the culprit. Unable to make bail, he was held in jail from the day of his arrest until his trial on October 23. Based on the testimony of four eyewitnesses, Collins was convicted of robbery and larceny and sentenced to not more than three and a half years in prison. Fortunately for Collins, another bag snatching took place the following week in the same area where the other bags had been taken. This time, the perpetrator (George Hill) was captured in hot pursuit carrying some of the stolen items. Stolen items were found in Hill's home that had been taken in the incidents for which Collins had been convicted. On October 30, 1928, Collins' motion for a new trial was granted and the charges nol prossed. Subsequently, Hill, whose height, weight, facial features and clothing closely resembled Collins', pleaded guilty to committing the crimes for which Collins had been convicted. A bill was introduced in the legislature to pay Collins $\$ 1,000$ compensation, but it was defeated, "one argument being that the state could not be required to bear expenses which ought properly to fall upon the counties. ${ }^{166}$

64 This account relies on BORCHARD, supra note 12, at 338-41 (1932). Borchard bases his account on archival papers and court records.

${ }^{65}$ See BoRCHARD, supra note 12 , at $46-60$.

${ }^{66} \mathrm{Id}$. at 50. 


\section{Angel D. Hernandez, Hampden County ${ }^{67}$}

At 7:30 p.m on December 9, 1987, a female college student was attacked at knife point as she was entering her car in Chicopee. Over a twenty minute period, the attacker sexually violated the victim in her car. He then fled. At 8:15 p.m., allegedly, police encountered Hernandez. On the basis of his general resemblance to the description of the rapist, the police obtained Hernandez's agreement to participate in a one-person show-up in front of a house where the victim had obtained refuge. Although Hernandez did not exactly match the victim's first description of the rapist, she identified him at the show-up and later in court. At his trial for rape and other charges, the jury hung. Tried again, Hernandez was convicted in 1988 of rape and other crimes. He was sentenced to twelve to eighteen years in state prison.

The major prosecution evidence against Hernandez was the victim's identification and the testimony of a forensic expert who had tested sperm and pubic hair left by the rapist. The expert testified that Hernandez's blood group was the same as the rapist's and that his pubic hair was "within the [same] range" as the rapist's. Finally, at the time of his arrest, Hernandez was carrying several surgical scrubs of the sort that could have been used to wipe biological evidence from his hands and penis.

Maintaining his innocence, Hernandez sought unsuccessfully in 1992 to gain access to the physical evidence for DNA testing. A second try, in 1998, proved successful. Testing conducted in August 2001 excluded Hernandez as the donor of the sperm on the victim's clothing. On August 15, 2001, after almost fourteen years incarceration, he was released. Hampden County District Attorney William Bennett apologized to Hernandez on behalf of the Commonwealth.

Following Hernandez's release, evidence emerged that the state had failed to disclose exculpatory evidence in his case. Hernandez had claimed at trial that the police were detaining him elsewhere at the time of the rape. The defense had requested computer printouts of the stop but none were produced by the police or prosecutor by the conclusion of the trial. In March 2002, however, the new District Attorney secured from the police a police computer printout which proved that Hernandez's alibi was true. ${ }^{68}$

${ }^{67}$ See Commonwealth v. Hernandez, 31 Mass. App. Ct. 1107 (1991), appeal denied, 411 Mass. 1103 (1991); Commonwealth v. Hernandez, 50 Mass. App. Ct. 1109 (2000) (allowing access to physical evidence for inspection and DNA testing); Brief for Appellant, Commonwealth v. Hernandez, 50 Mass. App. Ct. 1109 (2000); Kay Lazar, N.H. $A G$ Seeks to Block DNA Test on Man Serving Life, Boston Herald, Aug. 16, 2001, at 17.

${ }^{68}$ Emails from attorney Peter Neufeld, Cardozo Innocence Project (Aug. 5-12, 2002) (on file with author). 


\section{Donnell Johnson, Suffolk County ${ }^{69}$}

Jermaine Goffigan celebrated his ninth birthday on Halloween night, 1994. As he was counting his trick-or-treat candy outside the Academy Homes housing project in Roxbury, two young men walked up carrying firearms. In the storm of bullets they fired at a rival gang member, Jermaine was killed. Based on photographic identifications and a subsequent lineup, sixteen year-old Donnell Johnson was charged with delinquency by reason of first-degree murder. Convicted first at a juvenile court bench trial and then at a jury trial de novo, he was sentenced to eighteen to twenty years in prison.

The prosecution's case rested on identification testimony by several eyewitnesses whose view of the hooded attackers was hampered by darkness and poor artificial lighting. ${ }^{70}$ In a motion for a new trial, Johnson cited several instances of police and prosecutorial misconduct at trial. ${ }^{71}$ Chief among these was the suppression of a police report corroborating the defense claim that gang members from the Bromley-Heath housing project, in retaliation for the shooting of Kamaya Santos that occurred there earlier that night, did the shooting. The Supreme Judicial Court held that no prejudice ensued from the misconduct. Citing the "compelling" eyewitness testimony against Johnson," the court unanimously affirmed the convictions on appeal.

In 1999, a federal drug investigation led to charges against a number of Bromley-Heath gang members who offered to identify the "real" killer of Jermaine Goffigan. This led Suffolk County prosecutors to reopen Johnson's case. In November 1999, pursuant to a prosecution request, ${ }^{73}$ a juvenile court

69 See Commonwealth v. Kent K., 427 Mass. 754 (1998); SEAN FlynN, Boston D.A.: The Battle to Transform the American Justice System (2000); John Ellement, Polygraph Allegedly Backs Murder Defendant, BOSTON GLOBE, July 30, 1996, at B2; Andrea Estes, Slain Boy's Kin get \$550G; Landlord to pay settlement in '94 case, BosTON HERALD, Oct. 16, 1998, at 7; J.M. Lawrence, Johnson Case Puts Spotlight on Witness ID, BOSTON HERALD, Apr. 16, 2000, at 8; Putin Wins; Oil Flows; Clinton's Accused; Therapy's Hopeful; Conviction's Erased; Murders Multiply; Nurses Critical, BOSTON Globe, Apr. 2, 2000, at E4; David Weber, Prosecutor sure evidence solid in youth's '94 slaying, BOSTON HERALD, May 8, 2001, at 4; David Weber \& Jose Martinez, Gang Rivalry Fueled Hit; Source: Retaliation was Motive, BOSTON HERALD, May 5, 2001, at 5.

70 The victim's family later sued their landlord alleging poor lighting and security; in 1998 , they received a $\$ 550,000$ settlement. Estes, supra note 69 (noting that shooting area was known to residents as "the dark side" of the Academy Homes project).

71 These included an improper prosecution argument appealing to sympathy, police perjury or negligence in denying at his bench trial that Johnson had given them an exculpatory statement, failure to disclose a police report of that statement to the prosecutor until mid-way through Johnson's second trial, and failure to disclose an exculpatory report by Bromley-Heath security personnel. Kent K., 427 Mass. at 756-60, 762-63.

72 Id. at 758-59.

73 Suffolk County prosecutors reportedly reopened the case reluctantly and requested Johnson's release only after the defense took Johnson's claim of innocence to the press. Facsimile letter from attorney Stephen Hrones (Sept. 11, 2002) (on file with author). 
ordered Johnson's release from prison pending further investigation. On March 28,2000 , the court granted the prosecution's motion for a new trial. Prosecutors filed a nolle prosequi, indicating that newly-discovered evidence cleared Johnson.

In May 2001, Suffolk County prosecutors charged Michael Brown and Bennie Santos (the brother of Kamaya Santos) with Goffigan's murder. Both were members of a Bromley-Heath gang. Prosecutors said that Brown bore a striking physical resemblance to Johnson seven years prior. Some members of the victim's family, meanwhile, remained convinced of Johnson's guilt. In April 2002, Johnson brought a federal civil rights suit against the City of Boston and Boston police, alleging police perjury and suppression of exculpatory evidence in his case. ${ }^{74}$ Two months later, the Boston Police Department suspended the lead detective in the case for thirty days because of his misconduct in the case. ${ }^{75}$

\section{John McManus, Suffolk County ${ }^{76}$}

On the night of February 8, 1911, Boston police officer Joseph Balk observed a man, John Shorey, chasing and shooting at another man. Officer Balk pursued them and found Shorey standing over McManus, holding a gun in one hand and a gold watch and chain in the other. Shorey claimed that McManus had stolen his watch. McManus told a different story. He had been out looking for work shoveling snow when he encountered Shorey, who was upset after trying unsuccessfully to enter the apartment of a woman Shorey argued with earlier in the evening. Giving vent to his anger, Shorey attacked McManus. McManus turned and ran, with Shorey following and shooting. When Officer Balk came on the scene, Shorey made up the story about the watch.

Shorey was a deputy sheriff from Conway, New Hampshire; McManus was an unemployed immigrant laborer. Officer Balk believed Shorey and so did a jury. On the basis of Shorey's testimony, McManus was convicted of robbery and sentenced to three years in the House of Correction.

Fortunately for McManus, Shorey returned to Boston, got drunk, and was arrested for trying to force liquor on a newsboy and for carrying a pistol. Officer Balk happened to hear of the arrest and brought his suspicions to the District

${ }^{74}$ Francie Latour, State Lags in Aid for Exonerated Prisoners, Boston GloBE, Apr. 20,2002 , at B1. See also supra text accompanying note 71 . Johnson also complained that the photographic identifications were suggestive. The victim's mother had described one of the perpetrators as light skinned with freckles. Only one photograph in the array Johnson's - depicted a person with freckles. See Kent K., 427 Mass. at 762-63; Complaint, Johnson v. Mahoney, No. 0210730 MEL, at 16 (D. Mass. Apr. 19, 2002) (on file with author).

75 The suspension was for "negligence and case mismanagement" and for "failing to ensure the statements by the defendant were provided to the District Attorney's office in a timely manner." Michael S. Rosenwald, Review Board Suspends Detective Wrong Man Convicted in Death of 9-Year Old, BOSTON GLOBE, June 26, 2002, at B1. The detective appealed the suspension to the Civil Service Commission. Id.

76 See BORCHARD, supra note 12 , at 353-56. 
Attorney's office. The District Attorney assigned an investigator to the case, who concluded that McManus was innocent. On the District Attorney's recommendation, McManus was pardoned on February 28, 1912.

\section{Neil J. Miller, Suffolk County"}

On August 24, 1989, a black man forced his way into a white college student's apartment, where he robbed and raped her. During the hour-long attack, the victim had ample opportunity, in bright light, to observe the assailant's face and build. The victim later helped the police make a composite sketch of the rapist. Miller came to the attention of police because he resembled the composite drawing and the victim's description of the rapist. After she identified his photograph, ${ }^{78}$ he was arrested. In 1990, Miller was convicted of rape, robbery, and breaking and entering and was sentenced to prison for ten to twenty-five years. In 1997, he was denied parole "because he proclaimed his innocence and refused to enter treatment for sexual deviance." 79

The physical evidence at trial included a semen stain on the victim's bed sheet and a rape kit. The Commonwealth's forensic expert testified that, on the basis of blood-group testing, Miller was excluded as the source of the bed sheet stain but could not be excluded as a contributor to the rape kit material. In May 2000, DNA tests excluded Miller as the source of all of the biological evidence. The court granted Miller's motion for a new trial. The prosecution filed a nolle prosequi, stating that the new DNA evidence excluded Miller and that "further prosecution is not in the interests of justice." 80

A private bill to compensate Neil Miller is pending in the Massachusetts legislature. ${ }^{81}$

77 See Commonwealth v. Miller, 34 Mass. App. Ct. 1112 (1993), appeal denied, 422 Mass. 1108 (1996); Appellate Briefs, 422 Mass. 1108 (1996); Dave Wedge, Innocent Man Free After Long 10 Years, Boston Herald, May 11, 2000, at 3; Matthew Bruun, More Rely on "Miracle" of DNA Test Power to Convict, Exonerate, TELEgRaM \& GAZETTE, July 16,2000 , at B1.

${ }_{78}$ Miller was also wrongfully subjected to a suggestive courthouse identification procedure. Panel presentation by attorney Nona Walker, Panel Presentation at Harvard Conference on Wrongful Convictions (Apr. 20, 2002).

79 Wedge, supra note 77.

${ }^{80}$ Nolle Prosequi, Commonwealth v. Miller, Ind. No. 085602, at 3-5 (Mass. Super. Ct. May 10, 2000). Considering that the victim never reported the presence of multiple assailants, I conclude that this language implies the prosecutors' acknowledgement of Miller's innocence. However, the prosecutors did not explicitly acknowledge Miller's innocence in their public announcements or in the nolle prosequi.

${ }^{81}$ Kathleen Burge, The Price of Injustice, Boston Globe, May 29, 2001, at B1. 


\section{Marvin Mitchell, Suffolk County ${ }^{82}$}

On September 22, 1988, an eleven year-old Roxbury girl was raped on her way to school. She gave her mother a detailed description of the rapist, including the facts that he wore "pinkish" pants and had a mole or birthmark on his penis. The next day, the victim's mother drove around the neighborhood, saw Mitchell, and, based on her daughter's description, reported her belief that he was the rapist to police. ${ }^{83}$ Mitchell was arrested and charged with rape of a minor. In January 1990, a jury convicted him. He was sentenced to nine to twenty-five years in state prison. ${ }^{84}$

The prosecution evidence consisted of the victim's identification of Mitchell, whom she claimed to recognize from her neighborhood, evidence that Mitchell had a mole or freckle on his penis that resembled a mark that the victim had seen on the perpetrator's penis, expert testimony that analysis of blood mixed with semen found on the victim's sweatshirt did not definitively rule Mitchell out as a suspect, and police testimony that Mitchell had spontaneously confessed to wearing pink pants on the day of the rape.

On April 23, 1997, Mitchell won a new trial after DNA testing excluded him as the source of the blood and semen stains from the victim's sweatshirt. The District Attorney filed a nolle prosequi. Mitchell thus became the first Massachusetts prisoner to win release on the basis of new DNA evidence.

Mitchell subsequently sued the Boston Police Department and the City of Boston, seeking damages for an alleged conspiracy to convict him with fabricated evidence and perjured testimony. The City settled the suit for $\$ 450,000{ }^{85}$

\section{Arthur O'Connell, Suffolk County ${ }^{86}$}

In May 1935, twenty-six year-old Arthur O'Connell was tried in Boston for a sexual attack on a thirteen year-old girl. Convicted on the testimony of the alleged victim and that of her thirteen year-old companion who testified that she had witnessed the crime, O'Connell was sentenced to a term of not less than eight and not more than twelve years. In June of the same year, the "victim's" companion confessed that the crime had never occurred. O'Connell had merely stopped to talk to the girls for a moment. They had perjured themselves "just for fun." After a month's imprisonment, O'Connell was released.

82 See Commonwealth v. Mitchell, 35 Mass. App. Ct. 909 (1993), appeal denied, 416 Mass. 1108 (1993); Complaint and Jury Demand, Mitchell v. City of Boston, No. 98-3693 (Mass. Super. Ct. 2001); Mitchell v. City of Boston, 130 F. Supp. 2d 201 (D. Mass. 2001).

${ }^{83}$ See Complaint, Mitchell, No. 98-3693, at 99.

${ }^{84}$ In a verdict that appeared to compromise because of doubts about Mitchell's guilt, the jury convicted on one count of forced sexual intercourse and one count of forced unnatural sexual intercourse and acquitted on two identical charges. See Mitchell, 35 Mass. App. Ct. at $910 \mathrm{n} .1$.

${ }^{85}$ Telephone interview with attorney Noah Rosmarin (Oct. 10, 2001).

86 See Jerome Frank \& Barbara FranK, Not GuILTY 193-94 (1957). 


\section{Marlon Passley, Suffolk County ${ }^{87}$}

On the night of August 11, 1995, a motorcycle approached a group of six young men on a Dorchester street. The helmeted passenger, wearing a green mesh shirt, drew a gun and fired at the youths. At one point, he dismounted and, standing over them, shot three of the victims. The shots killed one, Tennyson Drakes, and seriously wounded the other two. Three of the young men identified the shooter to police as Passley, with whom one of their friends had fought two weeks before. They also claimed he had threatened them since. Four of the victims identified Passley's photograph. After Passley's arrest, police found a green mesh shirt in his apartment. At Passley's trial for first-degree murder and related offenses, the prosecution relied mainly on identification testimony by the four victim-witnesses. ${ }^{88}$ The defense presented the testimony of nine alibi witnesses and of the defendant to show that Passley was at a family graduation at Wellesley College at the time of the shooting. Passley was convicted as charged and sentenced to life imprisonment without possibility of parole.

In February 1999, the Supreme Judicial Court affirmed Passley's convictions and sentence. The following month, however, prosecutors obtained a court order temporarily staying his sentence on the ground that new evidence established that a different person had been the shooter. On September 13,2000, prosecutors persuaded a court to vacate Passley's conviction. Suffolk County Assistant District Attorney David Meier told the court: "I can state unequivocally, based on new evidence and credible facts, that Mr. Passley did not commit the crimes for which he was convicted." 89

In May 2001, a grand jury indicted John Tibbs for the murder of Tennyson Drakes.

${ }^{87}$ See Commonwealth v. Passley, 428 Mass. 832, 833 (1999); Appellate Briefs and Record, Passley, 428 Mass. 832; John Ellement, Shooting Victim Insists the Right Man was Convicted, Boston GlobE, Apr. 19, 1999, at B1; Shelley Murphy \& Ric Kahn, New Evidence Could Help Man Held for '94 killing, BOSTON GLOBE, Sept. 22, 1999, at A1; Sacha Pfeiffer, After Serving Four Years, Man is Exonerated in '95 Slaying, BostoN GLOBE, Sept. 14, 2000, at B6.

${ }^{88}$ They also introduced the green shirt into evidence, as well as expert testimony establishing that the shirt bore a tiny blood stain. Passley, 428 Mass. at 841 .

${ }^{89}$ Pfeiffer, supra note 87. At least one of the victims continues to believe that Passley was the shooter. See Jose Martinez, New Evidence in Murder Sets Somerville Man Free, Boston Herald, Apr. 18, 1999, at 9. 


\section{Santos Rodriquez ("Rodriguez"), Hampden County ${ }^{90}$}

Sometime on the evening of January 25, 1954, Mildred Hosmer was smothered to death in her Springfield home. She was found in bed, partially disrobed. Acting on knowledge that the victim had been drinking in the Franklin Grille earlier that night, police picked up Santos Rodriquez, who had also been there, for questioning. Rodriquez was a twenty-five year-old Puerto Rican busboy who knew little English. According to police, he confessed to the murder under questioning and reenacted the crime when taken to the victim's room. Afterwards, with the assistance of an interpreter, Rodriquez wrote and signed a confession in Spanish. These confessions were the main evidence against him at his trial for capital murder. The jury convicted Rodriquez of second-degree murder, and in December 1954, he was sentenced to life imprisonment.

Testifying through an interpreter at trial, Rodriquez admitted having been in the Franklin Grille on the night of the murder but denied ever speaking to the victim or going to her room. He said that the police forced him to write his confession and that "he wrote what they told him." Although rejected by the jury, Rodriquez's story gained credence in January 1956 when, driven by conscience, Lucien Peets confessed to Hosmer's murder. Peets was then in custody on other charges. After an investigation, Peets was indicted for manslaughter, pleaded guilty, and was sentenced to prison. The District Attorney supported Rodriquez's application for gubernatorial pardon, which he received in April 1957.92 In 1958, the legislature awarded Rodriquez, who had spent thirtynine months in prison, $\$ 12,500$ compensation.

90 See Commonwealth v. Rodriquez, 333 Mass. 501 (1956); Appellate Briefs and Record, Rodriquez, 333 Mass. 501; RADELET ET AL., supra note 1, at 342; Hugo BedAU, The Death Penalty in America 502 (Oxford University Press 1982) (1967); Conscience of Ex-Convict Leading to Man's Freedom, Boston DaILY GloBE, Apr. 5, 1957, at 1; Kenneth J. Cooper, The Price of a Wrong, Boston GloBE, May 13, 1984, at 1; Ray Richard, Rodriguez Is Freed, BosToN DAILY GlOBE, Apr. 10, 1957, at 1; Innocent "Lifer" Kept in Prison by Legal Snarl, BOSTON DAILY RECORD, Apr. 6, 1957, at 3; Man Indicted in Killing Clears Prison Inmate, Boston Daily Globe, Apr. 4, 1957, at 1; Man in Need, BOSTON AM., Jan. 16, 1958, at 1. Although secondary sources generally refer to the defendant as "Rodriguez," this Article follows the judicial pleadings and opinion in spelling his name "Rodriquez."

91 Brief for Commonwealth, Rodriquez, 333 Mass. 501, at 8.

92 See Conscience, supra note 90 . The District Attorney attributed the false confession to language difficulties, rather than police coercion. See id. Rodriquez's defense lawyer opposed pardon on the ground that his client "cannot be legally pardoned for a crime he never committed." Innocent "Lifer," supra note 90. The lawyer announced plans to file a motion in court to have Rodriquez "declared innocent of the murder so there never can be any doubt of the man's innocence." Id. I have been unable to find any later references to such a motion. 


\section{Eric Sarsfield, Middlesex County ${ }^{93}$}

On the afternoon of August 24, 1986, in Marlboro, a stranger approached a woman sweeping her patio. He forced her into her home and raped her. During the hour-long attack, the victim had ample opportunity to view the rapist. She later testified that she looked at the rapist's face during the entire attack and swore to herself that she would remember it. ${ }^{94}$ Four months later, under suggestive conditions, ${ }^{95}$ the victim identified Sarsfield as the rapist. Sarsfield, who had no criminal record, lived in the same area as the victim. In July 1987 a jury convicted him of rape. Sarsfield was sentenced to ten to fifteen years in state prison. Because he refused to admit his guilt, Sarsfield was refused parole several times before he was released in 1999.

Although a hospital rape kit and other physical evidence existed at the time of trial, no forensic analysis of this evidence was presented to the jury. The state rested its case entirely on eyewitness identifications by the victim and by Sarsfield's ex-wife, who identified a blurry videotaped image of the perpetrator in a nearby convenience store shortly before the attack as Sarsfield. Prosecutors also were allowed to impeach the defendant's testimony with an inculpatory statement that he allegedly made to a police officer in September 1986. The officer did not submit his report of this statement to the prosecutor until the week before trial, ten months after the statement was allegedly made. ${ }^{96}$

Helped by dedicated pro bono defense counsel, Sarsfield sought post-conviction DNA testing of the physical evidence. In October 1999, ${ }^{97}$ DNA testing of the rape kit and the victim's clothing excluded Sarsfield as the source of sperm and other biological material. On August 3, 2000, the court granted Sarsfield's motion for a new trial. The Commonwealth filed a nolle prosequi stating that the

93 See Commonwealth v. Sarsfield, No. 88-P-844, slip op. (Mass. App. Ct. 1989), appeal denied, 406 Mass. 1103 (1990); Appellate Briefs and Record, Sarsfield, 406 Mass. 1103; Motions for Post-Conviction Relief, December 29, 1997, and August 3, 2000; Nolle Prosequi, Commonwealth v. Sarsfield, No. 87-66-67 (Mass. Super. Ct. Aug. 4, 2000); Telephone interview with defense attorney George L. Garfinkle (Aug. 17, 2000); George L. Garfinkle, Presentation at offices of Testa Hurwitz \& Thibeault (Mar. 5, 2002).

${ }^{94}$ See Brief for Commonwealth, Sarsfield, No. 88-P-844, at 28.

${ }^{9}$ The victim selected Sarsfield's photograph from a photo array but was not positive that he was the perpetrator. Upon her request to see him in person, Sarsfield was displayed to the victim at a one-on-one show up at the police station, in the company of a police officer, wearing the jacket the rapist had left behind at the scene. The victim still could not positively identify him as the perpetrator. Subsequently, she selected his photograph again from an array. See generally Appellate Briefs, Sarsfield, 406 Mass. 1103.

${ }^{96}$ In May 1987, the court had ordered the prosecutor to disclose to the defense all oral statements of the defendant. Brief for the Defendant, Sarsfield, 406 Mass. 1103, at 2. The victim had described her attacker as having a small tattoo of a cross on his arm. Sarsfield, who was not tattooed, allegedly told the police officer that he sometimes drew tattoos on himself with washable ink. Id. at 12-13.

${ }^{97}$ Earlier in the same year, Sarsfield had been released on parole. 
evidence exonerated Sarsfield. After spending nine years in prison, Sarsfield was freed.

\section{Cornelius Usher, Essex County ${ }^{98}$}

In March 1902, Cornelius Usher was found pawning tools that had been taken during a burglary from the Leonard Shoe Company factory in Lynn. He claimed that while drinking he had met a man named Hart and then one "Jack" Coughlin. Coughlin asked him to pawn the tools. According to Usher, he did so without knowing that they were stolen. Disbelieved, Usher was charged with breaking and entering and theft. He was convicted and sentenced to three to five years in state prison.

Police did look for the "Jack" Coughlin described by Usher. Two years later, on April 16, 1904, John H. Coughlin, of Salem, was arrested for his involvement in the Leonard Shoe factory burglary. Publicity about the arrest induced the missing "Hart" to approach the police and verify that he had witnessed Coughlin hand the tools to Usher and tell him to pawn them. Coughlin subsequently pleaded guilty to breaking and entering into the Leonard Shoe Company and stealing the tools. He expressed regret that Usher had been punished for his crime. The District Attorney subsequently approved Usher's pardon application, which was granted on May 25, 1904. The following March, the Massachusetts legislature passed "a bill to indemnify Usher in the amount of $\$ 1,000$ 'as full compensation for his confinement for a period of 1 year, 11 months, and 26 days . . . for a crime of which he was innocent." mag

\section{Joseph Ward, alias Joseph Winston, Suffolk County ${ }^{100}$}

On February 19, 1895, a man who gave the name of James Mahoney was arrested in flagrante snatching the purse of a shopper at Jordan Marsh's store on Washington Street, Boston. His accomplice, however, got away. Based on eyewitness descriptions of the latter, police arrested Joseph Ward, alias Winston. Identified as the accomplice by the eyewitnesses, Ward was indicted to stand trial with Mahoney. However, Mahoney jumped bail, and Ward stood trial alone. Although Ward told his attorney that he was in another state on February 19, he was afraid to testify because of his criminal record. Ward was convicted on the testimony of several eyewitnesses. On April 18, 1895, the judge sentenced him to five years in state prison.

In July, Mahoney was rearrested. Ward's attorney, who believed in his client's innocence, told Mahoney of Ward's conviction as his accomplice. Mahoney said that Ward had not been his accomplice, but rather one Dooley, from New York. Police Inspector Knox, one of the eyewitnesses who identified

98 See BORCHARD, supra note 12, at 362-64.

99 BORCHARD, supra note 12 , at 363-64.

100 See BoRCHARD, supra note 12, at 364-67. See also Cornelius Usher is Now a Free Man, LYNn DaILy EVENING ITEM, May 26, 1904, at 1; Innocent Man Serving Time, LYNN DAILY EVENING ITEM, Apr. 21, 1904, at 1. 
Ward, investigated this claim and discovered that Dooley and Ward resembled each other. Convinced that Ward was innocent, Inspector Knox informed the prosecutor. Both the Inspector and the District Attorney wrote letters in support of Ward's pardon application. On January 30, 1906, after eight months of incarceration, Ward was pardoned on the ground of mistaken identity.

\section{B. Persons Who Were Not Officially Exonerated But Whose Convictions Were Vacated Under Circumstances Raising Strong Doubts About Their Factual Guilt}

In this Section, I describe twelve cases in which, as is true of the cases shown in Table A, the defendant's conviction was overturned. Although these defendants were not officially exonerated, their convictions were vacated under circumstances which, in my view, raise strong doubts about their factual guilt. I have omitted from this Section three cases ${ }^{101}$ that other scholars have described as

${ }^{101}$ The cases of Christian Amado, Louis Santos, and Charles Louis Tucker have been omitted.

Christian Amado was convicted in Suffolk County in 1980 of first-degree murder. See Commonwealth v. Amado, 387 Mass. 179 (1982); Appellate Briefs and Record, Amado, 387 Mass. 179; Pamela Constable, Murder Sentence Set Aside, Inmate Still Seeks to Get Out, Boston GlOBE, Aug. 25, 1982, at 35; Inmate Stabbed at Walpole, Boston GlOBE, Jan. 8, 1983, at 22; Diane Lewis, Court Orders Release of Inmate After He Served 2 Years of Life Term, BOSTON GLOBE, Aug. 21, 1982, at 13. The Supreme Judicial Court reversed Amado's conviction in 1982 because the trial court had erroneously failed to direct an acquittal. Retrial was barred. Radelet considered Amado innocent because " $[t]$ he only evidence linking Amado to the crime was an eyewitness who, as the court noted, first told police that Amado (in a photo) resembled the killer and then testified on the witness stand "that he was 'positive' that the defendant was not the killer." RADELET ET AL., supra note 1, at 283. Actually, the Court reversed because the eyewitness at trial denied identifying Amado to the police as the assailant. Therefore, under Massachusetts law, the trial court erred in admitting police testimony to the contrary to prove identification. See ERIC D. Blumenson et al., 1 MassachusetTs Criminal Practice 623 (1998) (a prior identification is not admissible at trial to prove identification unless the identifying witness acknowledges having made the out-of-court identification). In the absence, consequently, of any competent evidence of identification at trial, the conviction could not be sustained. Examination of the court's opinion, together with the appellate briefs and records, suggests the conclusion that, although Amado's guilt was not proved, he might well have killed the victim. The eyewitness, who testified before the grand jury that he feared retaliation if he identified the killer, might have identified Amado at the police station and recanted his identification at trial. In the court's words, his trial testimony about the identification procedures was "evasive and confusing." Also, other evidence in the case suggests Amado's factual guilt: he left for California after the incident and was arrested there; while awaiting trial, he faked an illness and then, after he was transferred to a hospital, escaped. See Appeal Overturns Conviction in Boston Murder, Boston GloBE, Aug. 20, 1982; Murder Suspect Stages Daring Hospital Escape, Boston GloBe, Aug. 1, 1980. The defendant also "attended the victim's wake, and, while there, claimed to have been 
wrongful convictions but which do not meet my criteria for "innocence."

'partners' with the victim; at the wake, the defendant was wearing clothing similar to that which [the eyewitness] described the assailant as having worn four days earlier." Amado, 387 Mass. at 189.

Louis Santos was convicted in Suffolk County in 1985 of armed robbery and felonymurder of a white social worker. The victim was accompanying a retarded client to the train when three black youths assaulted them, grabbed the victim's pocket book, and ran away. When she pursued and cornered them with her automobile, one of the boys fatally shot her. The chief evidence against Santos consisted of eyewitness identifications, some of which were made in highly suggestive circumstances, by three witnesses: the retarded man and two high school students heard shots and saw three black youths run past them. See generally Commonwealth v. Santos, 402 Mass. 775 (1988); Appellate Briefs and Record, Santos, 402 Mass. 775; Linda Matchan, Louis Santos: Did Justice Err?, BostoN Globe, Dec. 22, 1988, at 24; Doris Sue Wong, Accused Put Near Site of '83 Slaying, Boston Globe, Mar. 9, 1990, at 17; Doris Sue Wong, Judge to Permit Retarded Man to Testify in Murder Retrial, BOSTON GloBE, Mar. 8, 1990, at 27; Doris Sue Wong, SJC Overturns Murder Conviction in 1983 Slaying of Social Worker, BOSTON GLOBE, July 12, 1988, at 60; Doris Sue Wong, Suspect Was Identified, Police Testify, Boston GloBE, Mar. 10, 1990, at 28. Santos was sentenced to life imprisonment. In 1988, the Supreme Judicial Court reversed his convictions, citing the trial judge's erroneous decision to admit evidence of the retarded man's extra-judicial identification of Santos and her refusal to order a competency evaluation of that witness. Freed on bail after three years in prison, Santos was retried and acquitted.

Santos might well have been the victim of mistaken identification. On the other hand, the state produced other incriminating circumstantial evidence, including his flight from the police together with two other black youths, all three dressed similarly to the perpetrators, only minutes after the crime occurred, the fact that the victim's empty wallet was found near the point from which Santos admittedly fled from police, and Santos' motive to steal to support his drug use. See Matchan, supra. Applying Bedau and Radelet's approach to cases of appellative reversal followed by an acquittal, the Santos case does not appear to show "strong evidence that the defendant was indeed innocent." Bedau and Radelet, supra note 1 , at 47 .

In a celebrated and controversial case, Charles Louis Tucker was executed in the early 1900s for the stabbing death of a Weston woman. See David Hewett, Shreds of Evidence, Boston Mag. 75, Nov. 1983, at 133-38. Although Bedau and Radelet consider Tucker to have been innocent, my own review of the sources leaves me doubtful whether there was "strong evidence that the defendant was . . . innocent." RADELET ET AL., supra note 1, at 349. See conflicting views of the evidence presented in Commonwealth v. Tucker, 189 Mass. 457 (Mass. 1905); EDMUND LESTER PEARSON, MASTERPIECES OF MURDER: AN Edmund PEarson TRue Crime Reader 157-79 (Gerald Gross ed., 1963). 
Table B

Not "Officially Exonerated" But Convictions Vacated Under Circumstances Raising Strong Doubts About Factual Guilt

\begin{tabular}{|c|c|c|c|c|c|c|}
\hline Name & Convictec & Released & Crime ${ }^{102}$ & $\begin{array}{c}\text { Years } \\
\text { Incarceratec }\end{array}$ & DNA & Compensation \\
\hline Cero & 1927 & 1930 & Murder I & 3 & - & - \\
\hline Charles & 1984 & 2001 & Rape & 18 & Yes & - \\
\hline Ellison & 1974 & 1978 & Murder I & 4 & - & - \\
\hline Grace & 1974 & 1985 & Murder I & 11 & & - \\
\hline Harding & 1989 & 1995 & $\begin{array}{c}\text { Assl't. w/ } \\
\text { intent to } \\
\text { murder }\end{array}$ & 6 & - & $Y e^{103}$ \\
\hline Johnson, L. & $\begin{array}{l}1972, \\
1974 \\
\end{array}$ & 1982 & Murder I & 10 & - & Bill failed \\
\hline Leaster & 1971 & 1986 & \begin{tabular}{|l|} 
Murder I \\
\end{tabular} & 15.5 & $=$ & Yes ${ }^{104}$ \\
\hline Limone & 1968 & 2001 & Murder I & 33 & - & $\begin{array}{c}\text { Suit } \\
\text { Pending }\end{array}$ \\
\hline Reissfelder & 1967 & 1982 & Murder I & 13 & - & Bill failed \\
\hline Salvati & 1968 & 1997 & Murder I & 30 & - & Suit Pending \\
\hline Vaughn & 1984 & 1986 & $\begin{array}{c}\text { Armed } \\
\text { Robbery }\end{array}$ & 3 & - & Bill failed \\
\hline Waters & 1983 & 2001 & Murder I & 18 & Yes & - \\
\hline
\end{tabular}

\section{Gangi Cero, Suffolk County ${ }^{106}$}

Shortly after he left a Boston barbershop on a June afternoon in 1927, Joseph Fantasia was shot in the back and killed. The shooter dropped the gun on the ground and fled. A witness, who claimed to have seen the shooter run from the scene and enter a shop, called the police. Inside the shop, police arrested Gangi Cero, an Italian seaman. Cero was tried for first-degree murder, convicted, and

102 Most serious crime for which convicted.

103 Harding reportedly settled a civil suit against the City of Boston for a six-figure sum. See Jose Martinez, Man wrongly convicted in cop murder settles case, BosTON HERALD, Feb. 25, 2000, at 14.

${ }^{104}$ John Ellement, Freed Man Unlikely to Seek Redress Soon, Boston Globe, Nov. 25, 1999 , at B3. Leaster, given a $\$ 500,000$ annuity by the Massachusetts legislature in 1992 , is the only exonerated person to receive compensation in the past decade. Id.

${ }^{105}$ Civil suit pending.

106 See Commonwealth v. Gallo, 275 Mass. 320 (1931); Commonwealth v. Cero, 264 Mass. 264 (1928); Appellate Briefs and Record, Gallo, 275 Mass. 320; Appellate Briefs and Record, Cero, 264 Mass. 264; Bedau \& Radelet, supra note 1, at 103-04; RADELET ET AL., supra note 1, at 293-94; BEDAU, supra note 90, at 504; Sara R. Ehrmann, For Whom the Chair Waits, Fed. Probation, Mar. 1962, at 14, 19. 
sentenced to death. Although two new eyewitnesses came forward to swear that Cero was not the man they saw drop the gun and flee, his motion for new trial was denied.

Two hours before Cero's scheduled execution, he sent for the trial prosecutor and several others. Although at his trial Cero had denied firing the shot or running away, he now admitted that he had fled after seeing his employer, Samuel Gallo, shoot Fantasia. According to Cero, Gallo had brought Cero to the crime scene on a pretext and suddenly shot Fantasia without Cero's prior knowledge or assistance. Cero's claims were supported by another new eyewitness to the killing, Philomena Romano, who met with and helped persuade the Governor to grant Cero a reprieve. Several other facts pointed to Gallo's guilt. Gallo had a motive to kill Fantasia, and Cero did not. After Cero's arrest, Gallo had hired a lawyer to represent Cero and had given Cero money. Gallo had also attempted to bribe the Commonwealth's principal witness by offering him $\$ 2,500$ to recant his trial testimony. For this obstruction of justice, Gallo had been prosecuted and sentenced to jail. The witness later testified that Gallo, "in urging him to change his testimony ... said to him, '[i]f I were to tell you that I did it would that change your testimony?" 107 According to Cero, he originally protected Gallo because the latter had assured him that Cero would be exonerated and that, if not, Gallo "would go to the District Attorney and assume full responsibility for the murder of Fantasia." 108

In March 1929, Gallo was tried as the sole killer of Fantasia and convicted of murder. Because that verdict was inconsistent with the prior conviction of Cero for the identical crime, both verdicts were set aside and a third trial held, in which Cero and Gallo were tried as accomplices in the murder. While the Commonwealth presented evidence to show that both Cero and Gallo had guns and acted jointly, the jury convicted Gallo ${ }^{109}$ and acquitted Cero.

Comment: Although Gallo appears to have been Fantasia's actual killer, ${ }^{110}$ Cero might or might not have acted as his accomplice. At the least, his decision to perjure himself at his first trial in order to protect Gallo helped bring about his own close brush with the electric chair. While Cero's ultimate acquittal does not by itself establish his factual innocence, the facts do seem to raise strong doubts about his guilt.

107 Brief for Commonwealth, Gallo, 275 Mass. 320, at 5.

108 Id. at 1.

109 Gallo was later given another trial and acquitted. See H.R. DoC. No. 2575, at 26 (1959). Bedau and Radelet cite "later research" for their conclusion that Gallo was probably guilty of the crime. Bedau \& Radelet, supra note 1 , at 26 n.25.

${ }^{110}$ See supra text accompanying note 1 (suggestion of Bedau and Radelet that judicial reversal of a conviction followed by acquittal on retrial indicates error only when acquittal is based on "incontrovertible evidence that no crime occurred or on other strong evidence that the defendant was indeed innocent"). 


\section{Rodriguez Charles, Suffolk County ${ }^{111}$}

On the evening of December 8, 1980, a black man forced his way into a Brighton apartment shared by three young white women. There, he terrorized, robbed, and raped them all. Two of the victims later picked Charles' photo from a mug book. They also said that the perpetrator had a distinctive accent - Charles is from Trinidad, West Indies. Charles was absent from his arraignment and was not rearrested until 1983, nearly three years after the incident. A lineup was then held, where only two of the three victims identified Charles. Only one picked him out in the trial courtroom. The Commonwealth's case rested only on victim identification testimony without any corroborating confession or physical evidence. Although both the robe worn by one of the victims and a bed sheet bore biological stains, prosecution experts testified that no sperm was present. Blood tests excluded Charles as the donor. However, since the government claimed that no sperm was present, Charles was not excluded as the rapist. At trial, the prosecution argued that the stains had existed before the attack and that the assailant had not ejaculated. Charles was convicted and sentenced to four consecutive terms of eighteen to twenty years in prison.

Defense counsel had stipulated at trial that the hospital records showed that no sperm was found on the victims' vaginal swabs. After conviction, however, new defense attorneys discovered the victims' hospital records, which showed that sperm had been found on the vaginal swabs from two victims."12 Many years later, in the prosecution files, a defense attorney found interview notes, never disclosed to the defense, stating that the third victim believed that the assailant might have been circumcised. Charles is not circumcised. With the District Attorney's cooperation, DNA testing was performed on the robe and bed sheet, which, in 1999, revealed sperm from two different men, neither of whom was Charles. On May 11, 2001, a judge granted Charles' motion for a new trial on the ground that the new DNA evidence, and the previously suppressed victim statement that the attacker was circumcised, would likely have affected the jury's verdict. Therefore, "justice may not have been done in this case. ${ }^{n 13}$ The prosecution, which had vigorously opposed the new trial motion, announced its decision not to try Charles again. It cited as reasons the twenty-one years that had passed since the crime, lost evidence, and the death of the original investigators. ${ }^{14}$ However, the prosecution insisted that "[t]he absence of Charles'

111 See Commonwealth v. Charles, 397 Mass. 1 (1986); Appellate Briefs and Record, Charles, 397 Mass. 1; Memorandum of Decision and Order [allowing] Defendant's Motion for New Trial, Commonwealth v. Charles, Nos. 035492-45, 035181-84 (Mass. Super. Ct. May 11, 2001); Facsimile letter from attorney Stephen Hrones (Sept. 4, 2002) (on file with author).

112 The swabs themselves could not be located.

113 Memorandum of Decision and Order [allowing] Defendant's Motion for New Trial, at 19.

114 John Ellement, Victims of Brighton Rapes Speak Out; Suspect's Freedom Renews Anger, Fears, Boston Globe, May 29, 2001, at B1. 
DNA [at the crime scene] does not mean that he was not the rapist, as the facts presented at trial are otherwise convincing of his guilt." 115

Comment: This case illustrates how hard it can be to "know" or "prove" someone's factual guilt or innocence. Despite the DNA exclusion, Charles might have committed the rapes; perhaps, as the Commonwealth contended, the sperm stains on the robe and bed sheet were old and were contributed by the victims' previous, voluntary partners. Perhaps, as well, the victim mistakenly recalled that the rapist might have been circumcised. On the other hand, the government's case was built on vulnerable cross-racial witness identifications, and it lost potentially definitive scientific evidence - the sperm-bearing vaginal swabs. As a whole, the evidence raises strong doubts about Charles' factual guilt.

\section{Ella Mae Ellison, Suffolk County ${ }^{116}$}

On November 30, 1973, three young black men, Nathaniel Williams, Anthony Irving, and Terrell Walker, robbed a pawn shop in Roxbury. During the robbery, Walker fatally shot Boston Police Officer John Schroeder. Williams and Irving fled Boston. They were caught the next day, holding jewelry taken from the pawn shop. Under questioning, they made a number of incriminating statements to the police. Although they initially reported driving a stolen car to and from the robbery scene, one of them subsequently said they were driven by an unnamed, light-skinned black girl about eighteen years-old. Williams and Irving were offered the chance to plead guilty to seconddegree murder in return for their cooperation, but only if they identified the getaway driver. Ultimately, they said that Ella Mae Ellison had driven the three robbers to and from the pawn shop in her own car and accompanied them to one Freeman's apartment where they divided the loot. Ellison, a single mother of four children with no criminal record, was dark-skinned. At twenty-seven, she was also significantly older than the three drug-addicted robbers. At her trial in 1974 for armed robbery and firstdegree murder, she testified that in the past she had given Williams and Irving rides in her car but that she had no connection with the robbery. She was supported by Freeman and another witness from Freeman's apartment who testified that Ellison had not come there with the three robbers. However, based almost entirely ${ }^{117}$ on Williams' and Irving's testimony, the jury convicted Ellison

\footnotetext{
${ }^{115}$ Nolle Prosequi, Commonwealth v. Charles, Nos. 035492-45, 035181-84 (Mass. Super. Ct. May 16, 2001).

116 See Commonwealth v. Ellison, 376 Mass. 1 (1978); Appellate Briefs and Record, Ellison, 376 Mass. 1; RADELET ET AL., supra note 1, at 73-74; Correction, BOSTON GlobE, Oct. 8, 1988, at 2; Kevin Cullen, 2 Jailed in Officer's Slaying Seek Parole, Boston Globe, Oct. 7, 1988, at 27. See also Walker v. Butterworth, 599 F.2d 1074 (1st Cir. 1979); Commonwealth v. Walker, 370 Mass. 548 (1975), cert. denied, 429 U.S. 943 (1976).
}

117 A Boston police officer also testified to an incriminating remark allegedly made by Ellison when he first interviewed her about the crime. On cross-examination the officer conceded that his written report of the interview did not refer to any such conversation 
as charged. ${ }^{118}$ She received concurrent life sentences.

At a hearing in 1976 on Ellison's motion for a new trial, she presented new evidence on two issues. First, despite repeated defense requests for exculpatory evidence, the prosecution had suppressed several early statements by Williams and Irving that supported the claim that Ellison was not involved in the crime. Second, Williams and Irving recanted their trial testimony incriminating Ellison and reaffirmed their original admissions that they drove themselves to the crime scene in a stolen car. Although the trial court denied Ellison relief, the Supreme Judicial Court vacated her conviction in 1978. Noting that "the Commonwealth's case at trial was a dubious one," 19 the court held unconstitutional "[t]he prosecutor's late, piecemeal, and incomplete disclosures" of earlier, exculpatory statements by Williams and Irving. ${ }^{120}$ Regarding the recanted testimony, the court pointed out that Williams and Irving, who had given several conflicting versions of the crime, "emerge as very willing to lie under oath." 21 The court speculated that their motives for falsely inculpating Ellison might have been to obtain the benefits of the offered plea bargain or, alternatively, to protect the identity of the real getaway driver.

Following the court's reversal of Ellison's conviction, the District Attorney dropped charges against her. ${ }^{122}$

Comment: Although neither the prosecutor's action nor the Supreme Judicial Court's decision can be said to manifest official exoneration of Ellison, her conviction was reversed in circumstances raising strong doubts about her factual guilt.

\section{Frank Grace, Bristol County ${ }^{123}$}

In the early 1970s, Frank Grace was a Black Panther leader in New Bedford. Under surveillance by the FBI, he had been arrested numerous times by the local police but never convicted. On the night of August 8, 1972, outside a New Bedford night club, two men with guns attacked Marvin Morgan, a nineteen year-

with Ellison. See Ellison, 376 Mass. at 13.

${ }^{118}$ In a separate, earlier trial, Walker was convicted of the same crimes. See Walker, 370 Mass. 548.

119 Ellison, 376 Mass. at 17.

120 Id. at 25.

121 Id. at 19.

122 See Correction, supra note 116.

123 See Commonwealth v. Grace, 397 Mass. 303 (1986). See also Commonwealth v. Grace, 381 Mass. 753 (1980); Commonwealth v. Grace, 376 Mass. 499 (1978); Commonwealth v. Grace, 370 Mass. 746 (1976); RADELET ET AL., supra note 1, at 308; Martin Yant, Presumed Gullty: When Innocent People Are Wrongly Convicted 194-97 (Robert Basil \& Mary Beth Gehrman eds., 1991); Steve Curwood, Murder Case Witness in '74 Says He Lied, Boston Globe, Sept. 14, 1984, at 17; Steve Curwood, A Murder Conviction Overturned After 11 Years for Former New Bedford Black Panther Leader, Boston GloBe, Jan. 16, 1985, at 19; Former Black Panther Leader Gets Retrial, Boston GloBE, May 21, 1986, at 84. 
old drug addict. One of the men fatally shot the victim. According to two eyewitnesses, Jasper Lassiter and Eric Baker, the culprits were Frank Grace and his brother Ross. At trial in 1974, both witnesses identified Frank as the shooter. Although Frank, supported by seven witnesses, testified to an alibi, the jury convicted him of first-degree murder. He was sentenced to life imprisonment. His brother, Ross, was convicted of second-degree murder of the same victim.

Ten years later, in the summer of 1984, hearings were held on Frank Grace's motion for a new trial. He presented four eyewitnesses who testified that he neither shot Morgan nor was present at the scene of the crime. Two of the witnesses had testified against Grace at trial and now recanted. Lassiter testified that he had never seen Frank before the trial, but was urged and coached by the police to identify him as the shooter. In truth, he swore, Ross Grace had shot the victim. At the same hearing, Ross Grace recanted his alibi testimony and admitted that he, not Frank, had shot the victim. He insisted that Frank had not been present. Also, two newly discovered eyewitnesses testified that Frank had not been present at the crime. Finally, two lawyers swore that Ross Grace had told them that he had shot the victim and that Frank had not been there. Based on this new evidence, the Superior Court ordered a new trial for Frank, who was released on bail in January 1985. Successfully appealing the new trial order, prosecutors were able to send the case back to the Superior Court for a rehearing. However, this resulted in another, uncontested order for new trial. Prosecutors decided not to re-prosecute Grace, citing as reasons both the Superior Court's findings and the unavailability of necessary witnesses.

Comment: Frank Grace maintained that the police had framed him because he was a political radical. Regardless of whether that is true, Frank's failure to point the finger at his brother Ross, assuming that he had the ability to do so, might have contributed to his own conviction. Still, the evidence as a whole raises strong doubts about Frank's factual guilt.

\section{Christopher Harding, Suffolk County ${ }^{124}$}

On August 18,1989, two men shot and wounded Deron Jones in the Mission Hill housing project in Boston and then fired on pursuing police officers. One of the men, a reputed drug lord named Dwayne Owens, surrendered to police at the

124 See Commonwealth v. Harding, 36 Mass. App. Ct. 1124 (1994), appeal denied, 418 Mass. 1105 (1994); Appellate Briefs, Harding, 36 Mass. App. Ct. 1124; Defendant's Memorandum in Support of Motion for New Trial; Memorandum and Order on Defendant's Motion for New Trial; [Draft of] Complaint, Harding v. City of Boston; interview with attorney Robert S. Sinsheimer (December 27, 2001); Jose Martinez, Man Wrongly Convicted in Cop Murder Settles Case, Boston HeRALD, Feb. 25, 2000, at 14; Mitchell Zuckoff, Boston Police "Testilying" Leaves Trail of Injustice, BOSTON GLOBE, Dec. 7, 1997, at Al [hereinafter Zuckoff, Boston Police]; Mitchell Zuckoff, DA Clears Man Convicted by Police Lies, Boston GloBE, Jan. 24, 1998, at B1 [hereinafter Zuckoff, DA Clears Man]; Mitchell Zuckoff, Judge Assails Police, Grants Man New Trial, BostoN GLOBE, Dec. 23, 1997, at A1 [hereinafter Zuckoff, Judge Assails]. 
scene. ${ }^{125}$ Police Officer Terence O'Neil claimed that he saw Harding shoot twice at Jones and once at him, throw down a gun, and flee into an adjacent building. Harding was found there sitting on a staircase. Officers O'Neil and Stratton identified Harding as the second shooter, as did the victim's companion, Glenn Hill, after he was showed Harding lying in the rear seat of a police cruiser.

Harding, who lived in the building where he was arrested, testified at trial that he was asleep when Officer O'Neil woke him up and arrested him. An alcoholic, he frequently slept on that staircase when he was too drunk to go home. Harding's claim was supported by a witness who testified that she had seen Dwayne Owens shortly before the crime with a second man who was not Harding. But on May 25, 1990, Harding was convicted of two counts of assault with intent to murder and other offenses. He was sentenced to ten to twelve years in state prison. His conviction was not supported by any physical evidence or motive but rested mainly upon the identification testimony of the two police officers and Hill. According to Officer O'Neil, when he found Harding on the staircase, Harding was sweating and his heart was racing. Officer $O^{\prime} N e i l$ also testified that Harding made an incriminating statement to him.

In October, 1995, after serving six years in prison, Harding was released. ${ }^{126}$ Meanwhile, a federal grand jury was investigating Dwayne Owens' gang activities. In grand jury testimony, Glenn Hill recanted his identification of Harding as the second shooter of Deron Jones. Cooperating gang members testified that Dwayne Owens had admitted that his cousin, Robert Owens, was the second shooter. One witness swore that he had seen the two cousins together shortly before the crime. Harding was ten years older than Dwayne Owens and had no known association with Owens' gang. Based on this testimony, the presiding judge at Owens' federal criminal trial urged state authorities to reexamine Harding's conviction. ${ }^{27}$ Citing the newly discovered evidence, Harding filed a motion for a new trial in 1997.

On December 22, 1997, Superior Court Judge Volterra granted Harding's motion without first hearing witnesses, citing "the compelling nature and righteousness" of Harding's claims. He listed a number of reasons for having "serious questions about the veracity" of the police testimony at Harding's trial. Ballistic evidence contradicted Officer O'Neil's testimony as to the number of shots he heard. Also, Officer O'Neil had disobeyed a court order by speaking with another police witness at the trial, after which the second officer allegedly changed his testimony. Police had obstructed defense efforts to subpoena as a witness Police Officer Justina Mitchell, who was Officer O'Neil's partner on the night of the incident and whose incident report was inconsistent with the testimony of her brother officers. Boston Police Department supervisors had improperly ordered Officer Mitchell not to honor a valid defense subpoena for

125 Owens later jumped bail and was still a fugitive when Christopher Harding was tried.

126 Zuckoff, DA Clears Man, supra note 124.

127 See Zuckoff, Boston Police, supra note 124. 
her testimony. They then falsely informed the prosecutor and the trial judge that Officer Mitchell was away in Florida, when in fact she was at a police station in Roxbury. Judge Volterra called this episode a "fraud upon the court." He also pointed to affidavits of several newly discovered witnesses in support of Harding's alibi and found Harding's trial lawyer ineffective for failing to seek them out. ${ }^{128}$ Finally, the judge noted that the police had lost the hat and jacket worn by Harding on the night of his arrest, which the defense claimed were different from those worn by the perpetrator.

In January 1998, prosecutors announced their decision not to retry Harding. As reason, they stated only that retrial would not serve the interests of justice. ${ }^{129}$ Harding subsequently sued the police for causing his wrongful conviction by perjured testimony. In January 2000, the City of Boston settled the suit for $\$ 480,000 . .^{130}$ The following month, the police department fired Officer O'Neil "for lying under oath and other breaches of department rules during the [Harding] case." 131

Comment: The Harding case illustrates why students of "miscarriages of justice" should cast their nets beyond the narrow category of "official" or "undisputed" exonerations. The facts seem to compel the conclusion that police arrested, charged, and convicted the wrong man. Yet, the state's executive branch authorities have not acknowledged Harding's innocence. Under the circumstances, this failure is hard to understand except as an act of selfprotection.

\section{Lawyer Johnson, Suffolk County $y^{132}$}

On December 7, 1971, James Christian, a white man seeking to buy drugs, was shot to death as he left a building on Prentiss Street in Roxbury. Kenny Myers, a drug addict found by police at the murder scene, told police that he saw Lawyer Johnson, age twenty, and another black man attempting to rob Christian. When the latter pulled a gun, Johnson reportedly shot him in the face and fled with the second man. Myers then took and hid the victim's gun, to which he later

128 See Zuckoff, Judge Assails, supra note 124.

129 See Zuckoff, DA Clears Man, supra note 124. Previously, the trial prosecutor expressed "significant concerns regarding the justice of $\mathrm{Mr}$. Harding's conviction." Zuckoff, Boston Police, supra note 124.

${ }^{130}$ Harding's trial lawyer paid Harding an additional $\$ 25,000$. See telephone interview with attorney Robert S. Sinsheimer (Dec. 27, 2001).

131 Martinez, supra note 124.

132 See Commonwealth v. Johnson, 13 Mass. App. Ct. 10 (1982); Commonwealth v. Johnson, 372 Mass. 185 (1977); Commonwealth v. Johnson, 365 Mass. 534 (1974); Appellate Briefs and Record, Johnson, 372 Mass. 185; Appellate Briefs and Records, Johnson, 365 Mass. 534; RADELET ET AL., supra note 1, at 371; Newsletter of Mass. Citizens Against the Death Penalty (Boston), Winter 1984, at 3; Betsey A. Lehman \& Joseph M. Harvey, Murder Charge Dropped, He's a Free Man Again, Boston GlobE, Oct. 20, 1982, at 25; Robert L. Turner, Three Cases Against the Death Penalty, BostoN GloBE, July 1, 1982, at 15 . 
led the police.

On June 1, 1972, Johnson was convicted by an all-white jury of first-degree murder and was sentenced to death. On appeal, the Supreme Judicial Court reversed the conviction because the trial judge had improperly restricted Johnson's right to cross-examine Myers. ${ }^{133}$ Retried, Johnson was convicted again by an all-white jury on November 16,1974, this time only of second-degree murder. His conviction and sentence to life imprisonment were affirmed on appeal. ${ }^{134}$

The prosecution case against Johnson rested primarily ${ }^{135}$ on the testimony of Myers and of Alvin Franklin, who had shared a cell with Johnson before the first trial. Franklin testified that Johnson confessed committing the murder to him. As noted by the appellate courts, the trustworthiness of both prosecution witnesses was "certainly questionable. Myers, with a criminal record, and himself not clear of suspicion of the homicide, was a difficult and reluctant witness" 136 who told "conflicting, shifting stories," identified Johnson as being present at the murder scene only after the police had indicated that they could 'get' Myers himself for the murder." 138 Furthermore, both Myers and Franklin "were under pressure of their forthcoming trials on criminal charges at which they could hope that any past cooperation might earn them favor from the prosecutor." 139 These weaknesses in the Commonwealth's case were compounded by the emergence of two new eyewitnesses in Johnson's favor. The first, Garry Pritchett, was a youth worker who was present at the scene and whose value as a witness was obscured by the prosecution's initial suppression of a key statement by Myers. ${ }^{140}$ At Johnson's second trial, Pritchett testified to seeing Myers and two other black men run from the murder scene; neither of the other two men was Johnson. Although Pritchett's testimony did not move the second trial jury to acquit Johnson, a court was persuaded on July 6 ,

133 Johnson, 365 Mass. at 579.

134 Johnson, 372 Mass. at 220.

135 The Commonwealth also presented a police witness who testified that when he questioned Johnson soon after the crime, Johnson gave him a false name and address. See id. at 188.

136 Id. at 189.

137 Johnson, 13 Mass. App. Ct. at 11. Myers had originally identified the photograph of another man as the killer. Only after learning that that man was in prison did he accuse Johnson.

138 Id. at 12.

139 Johnson, 372 Mass. at 189. Montiero's mother testified that Montiero had told her about the shooting on the day it occurred.

${ }^{140}$ See Johnson, 365 Mass. at 548-50 (Commonwealth failed to disclose Myers' signed statement of December 7th, in violation of court's pretrial discovery orders; court attributes this and other prosecution failures to carry out pretrial court orders to calendar pressures on overworked prosecutors). Pritchett testified that he had voluntarily told his story to a police officer at the scene who took notes. Pritchett's claim was corroborated by Myers' testimony. The police officer later had no record or recollection of the incident. 
1981 , to grant Johnson a new trial based on the testimony of a second new eyewitness, Dawnielle Montiero. As a neighborhood ten year-old, Montiero had known both Myers and Johnson. In motion hearing testimony, corroborated by her mother, she swore that Johnson "was not present at the scene and that Myers ... himself had fired three shots at the victim." ${ }^{141}$ She attributed her failure to come forward earlier to her fear of Myers. ${ }^{142}$

The prosecution appealed the order granting Johnson a new trial. While acknowledging that reasons existed to doubt both Pritchett's and Montiero's testimony, ${ }^{143}$ the Court of Appeals affirmed the new trial order. ${ }^{144}$ The prosecution declined to retry Johnson. Calling his release a "travesty of justice," the trial prosecutor said that he was forced to drop the charges because Myers refused to testify again. ${ }^{145}$

After ten years in prison, including two years on death row, Johnson was freed on October 19, 1982. ${ }^{146}$ In 1983 , both houses of the Massachusetts legislature voted to compensate him in the amount of $\$ 75,000$. However, the legislature failed to give the bill final approval. Another compensation bill was filed on Johnson's behalf in 1999 , but it too failed to pass. ${ }^{147}$

Comment: Unsupported by any physical evidence, Johnson's conviction for capital murder rested on testimony from two blatantly untrustworthy witnesses. Myers was a prime suspect in the murder. He was present at the scene, possessed the victim's gun, and lied to the police, the grand jury, and the courts. Franklin had the tainted credibility of a jailhouse snitch. While the truth might never be known, the case raises strong doubts about Johnson's factual guilt.

\footnotetext{
141 Johnson, 13 Mass. App. Ct. at 14.

142 Montiero testified that immediately after she witnessed the shooting she called the police who said that because of her age, she "couldn't help them anyway." Id. at 14.

${ }^{143}$ The court cited the Supreme Judicial Court's conclusion that Pritchett's testimony was "clouded by suspicion that he was shaping his testimony to help save a friend." Id. at 13 (quoting Johnson, 372 Mass. at 190). Both Montiero and her mother had social ties to Johnson and his family. Johnson, 13 Mass. App. Ct. at 14-15. On the other hand, several community leaders submitted affidavits attesting to Pritchett's excellent character.

144 The Appeals Court denied the Commonwealth's appeal and affirmed the order for a new trial on January 6, 1982. Johnson, 13 Mass. App. Ct. at 10.

145 "We reluctantly dismissed the indictment because of the age of the case and the unavailability of witnesses." Lehmann \& Harvey, supra note 132.

${ }^{146}$ He was released on bail in February 1982. Id.

${ }^{147}$ Mark Mueller, Legislators Paid Leaster for Error, but Not Johnson, BosTON HERALD, Feb. 22, 1999, at 22.
} 


\section{Bobby Joe Leaster, Suffolk County ${ }^{148}$}

On Sunday afternoon, September 27, 1970, two black ${ }^{49}$ men robbed a variety store on Talbot Avenue in Dorchester. One of them shot and killed the owner, Levi Whiteside, in the presence of his wife, Kathleen, and a customer, Nellie Rivera. The shooter wore a black beret, a black shirt, and green pants. Kathleen told police that both men had been in her store earlier that day, acting suspiciously. Ninety minutes later, police arrested Bobby Joe Leaster, whose physical description and dress resembled the shooter's, on a street in the South End. Brought to Boston City Hospital, Leaster was sitting handcuffed in the rear of a patrol wagon as Kathleen emerged from the hospital. Led by a police officer, she approached the vehicle and identified Leaster as the killer. A short while later she confirmed the identification in the police station where, surrounded by police officers, Leaster was the only black man in the room. Under equally suggestive circumstances, Rivera also identified Leaster. Leaster was convicted of first-degree murder on June 22, 1971, and was sentenced to life imprisonment. The jury recommended that the death penalty not be imposed!50

The prosecution case against Leaster rested entirely on eyewitness identification testimony. Although the trial court suppressed both eyewitnesses' stationhouse identifications, it admitted Kathleen's hospital identification and in-court identifications by both witnesses. The jury rejected testimony by Leaster and his girlfriend that they had been together in their South End home when the crime occurred. Leaster's ability to mount a successful defense was weakened by the prosecution's failure to disclose exculpatory evidence and weaknesses in the defense presentation.

On July 25, 1986, over the District Attorney's opposition, the Advisory Board of Pardons voted unanimously to recommend commutation of Leaster's sentence. Impressed by his good prison record, the Board took this action despite, rather than because of, Leaster's continued claim of innocence. Before Governor Dukakis could act on the Board's recommendation, a new eyewitness came forward. In response to a newspaper article on Leaster, showing Leaster's

148 See Commonwealth v. Leaster, 395 Mass. 96 (1985); Leaster v. Commonwealth, 363 Mass. 407 (1982); Commonwealth v. Leaster, 385 Mass. 547 (1972); Appellate Briefs and Record, Leaster, 363 Mass. 407; Appellate Briefs and Record, Leaster, 385 Mass. 547; Don Aucoin, State Gives Leaster 1st Payment as Apology for Years in Prison, Boston Globe, Nov. 13, 1992, at 22; George Esper, When the Law Tells Time: Justice Delayed or Justice Denied? Man Wins New Trial 15 Years After His Conviction in Murder of Storekeeper, L.A. TIMES, Dec. 14, 1986, at 2; Charles Kenney, The Trials of Bobby Joe Leaster, Boston Globe MAG., July 27, 1986, at 19; Paul Langner, Lessons in Injustice; Wrongly Jailed Man Offers Insights on Court Failings to Students, BOSTON GloBE, July 27, 1995, at 23; Murder Charge Dropped; Man Served 15 Years, L.A. TIMES, Dec. 27, 1986, at 28; New Evidence Cancels Verdict in '70 Murder, N.Y. TiMES, Nov. 5, 1986, at A24; John H. Kennedy, New Witness to '70 Hub Killing Prompts Retrial Bid, Boston Globe, Sept. 16, 1986, at 17.

149 The victim and his wife, Levi and Kathleen Whiteside, were also black.

150 Commonwealth v. Leaster, No. 52235 (Mass. Super. Ct. June 22, 1971). 
photograph, the witness, a Boston teacher and constable, came forward to report that he had seen two men running from the victim's store right after the killing. One was wearing a beret. Neither that man, whom he knew, nor the second man, was Leaster. ${ }^{151}$ Based on this new evidence, on November 3, 1986, Leaster won a new trial. In the meantime, the District Attorney's office had reopened the case. Prosecutors learned that the Whiteside murder weapon had been used in another robbery sixteen days after the killing, while Leaster had been in custody. ${ }^{152}$ Another man, Kelsey Reid, had been seen buying a similar pistol ten days before the Whiteside killing and had reportedly bragged later about committing the murder for which Leaster was punished. ${ }^{153}$ Requesting dismissal of the indictments against Leaster in December 1986, prosecutors told the court: "we can't say that Leaster . . . did [the 1970 crime], and we can't say that he didn't." "154

The Massachusetts legislature, however, had no such difficulty. On Nbvember 12 , 1992, the legislature appropriated money to fund a $\$ 500,000$ annuity to benefit Leaster and his son. According to the statute, the annuity was intended to discharge the Commonwealth's "moral obligation" to Leaster, "his conviction having been vacated on the basis of newly discovered evidence establishing his innocence ...."155 In presenting the first payment to Leaster, the House Speaker apologized to him for his fifteen year incarceration. ${ }^{156}$

Comment: Like Harding's case, ${ }^{157}$ Leaster's case illustrates the value of expanding the domain of "wrongful convictions" beyond those cases in which either a responsible executive or judicial authority has determined the prisoner's factual innocence. The same new exculpatory evidence that left prosecutors agnostic as to Leaster's guilt convinced the state legislature to declare his innocence, apologize, and award him compensation. No sufficient reason exists for effectively disregarding the legislative judgment. ${ }^{158}$

151 The witness, Mark Johnson, was thirteen at the time of the crime. The article to which he responded was Kenney, supra note 148 . Johnson identified the man wearing the beret by name. See id.

152 See Murder Charge Dropped, supra note 148. The gun had been in police custody since 1970 but not matched to the Whiteside killing until 1986. Id.

${ }^{153}$ See Charles Kenney, Justice for Bobby Joe, Boston Globe MAG., Feb. 28, 1988, at 50.

${ }^{154}$ Murder Charge Dropped, supra note 148. Reportedly, Kathleen Whiteside remained " $100 \%$ certain" that Leaster was guilty. Id.

1551992 Mass. Acts 153, §65.

156 See Aucoin, supra note 148.

157 See supra text accompanying note 124.

158 See supra text accompanying notes $41-46$. 


\section{Peter J. Limone, Suffolk County ${ }^{159}$}

One of the "Salvati Four," Peter Limone spent thirty-three years in prison before his release in January 2001. His case is described below in this Section in the entry for Joseph Salvati. Mr. Limone has filed a suit for damages against federal and state authorities. ${ }^{160}$

\section{George Reissfelder, Suffolk County ${ }^{161}$}

On October 14, 1966, two armed men committed a payroll robbery at Railway Express in Boston. One of the men, later identified as William Sullivan, fatally shot one of the guards. Three of the victim's fellow employees later identified George Reissfelder as the second robber. When arrested, Reissfelder possessed a .22 caliber revolver, which one of the three identified as the gun brandished by the second robber. On July 21, 1967, a jury convicted both Sullivan and Reissfelder of first-degree murder. The jury rejected the prosecution's request for death sentences, and each defendant was sentenced to life imprisonment.

The state's case against Reissfelder rested on weak and suggestive eyewitness identification, ${ }^{162}$ but Reissfelder's alibi defense was also weak. In 1972, Reissfelder's co-defendant, Sullivan, dying in prison of leukemia, confessed to a priest that he had never met Reissfelder before the two stood trial. He asked the priest to apologize to Reissfelder. The priest subsequently came forward, and Reissfelder sought a new trial. At a hearing in June 1982, defense attorneys presented ten witnesses in support of Reissfelder's claim of innocence, including five policemen, an FBI agent, a probation officer, and the priest. Several police officers testified to hearing from informants during the investigation that Reissfelder was not involved. A Boston detective testified that he had told a sergeant working on the case about informant claims that Sullivan and two other

159 See infra note 169 , sources cited for Joseph Salvati case.

160 Thanassis Cambanis, Wrongful Imprisonment lawsuit is filed against FBI, BosTON GloBE, May 16, 2002, at A21 (announcing joint suit by Mr. Limone and representatives of the estates of Enrico Tameleo and Louis Greco).

161 See Commonwealth v. Sullivan, 354 Mass. 598 (1968), cert. denied, 393 U.S. 1056 (1969). See also Sullivan v. Scafati, 428 F.2d 1023 (1st Cir. 1970) (co-defendant's appeal from deniai of habeas corpus); Appellate Briefs and Record, Sullivan, 354 Mass. 598; RADELET ET AL., supra note 1, at 340-41; Martie Barnes, He's Lost Patience Waiting for Justice, Boston Globe, Dec. 3, 1984, at 28; Richard J. Connolly, Retired Boston Official Quoted in New-trial Bid, Boston GloBe, June 23, 1982, at 21; Charles Craig, No One Will Admit to Suggesting Gardner Deal, BOSTON HERALD, May 29, 1992, at 27; Imprisoned in ' 66 Killing, He Goes Free in Boston, N.Y. TIMES, Aug. 31, 1982, at A10; Florida Votes Parole in "Wrong Man" Case, BOSTON GlOBE, Aug. 26, 1982, at 28; Eric Rubin, Life-termer Reissfelder Hopes to be Free Soon, Boston GLOBE, July 23, 1982, at 18; Ex-convict Loses Bid for State Restitution, Boston GloBE, Dec. 15, 1985, at 46; Joan Vennochi \& Diane Lewis, Cleared of Murder Charge, He Wants to Forget the Past, BOSTON GlOBE, Aug. 31, 1982, at 40.

${ }^{162}$ The eyewitnesses had only seconds to view the second robber. They saw him in a dark hallway, disguised in sunglasses and a hat. 
Charlestown men, not Reissfelder, committed the crime. The sergeant allegedly replied: "Don't rock the boat, kid. We're all set." 163 A prison case-worker testified that in 1968 that Sullivan had revealed Reissfelder's innocence to him. ${ }^{164}$ Sullivan's former defense lawyer also told prosecutors that he believed that Reissfelder was innocent. Finally, there was testimony that Reissfelder did not come into possession of the alleged robbery weapon until at least five hours after the crime. In July 1982, the court granted Reissfelder's motion for new trial. The District Attorney announced that he would not try Reissfelder again and did not oppose Reissfelder's motion to dismiss the charges. Reissfelder was freed on August 30,1982 , sixteen years after he was first imprisoned. ${ }^{165}$

Following Reissfelder's release, the legislature twice failed to pass a private bill to award him compensation. ${ }^{166}$ He died in 1991 "of acute cocaine poisoning." 167

Comment: Although Reissfelder's factual innocence was never declared by an executive or judicial authority, the facts of his case raise strong doubts about his factual guilt.

${ }^{163}$ Connolly, supra note 161. Compare Jones v. City of Chicago, 856 F.2d 985, 99091 (7th Cir. 1988) (stating that a detective who told colleagues exculpatory information about murder suspect warned not to interfere with investigation), discussed in Fisher, supra note 18 , at 1, 2-4 (1993).

${ }_{164}$ Because he felt it was not his responsibility, he told no one but his wife. See id.

165 Because he escaped while on furlough and lived for three years as a fugitive in Florida, he actually spent only thirteen years in prison on this charge.

${ }^{166}$ Ex-convict Loses Bid, supra note 161.

167 Craig, supra note 161 . 


\section{Joseph Salvati and other members of the "Salvati Four," County ${ }^{169}$}

On March 12,1965, a group of men connected to organized crime planned and executed the fatal shooting of Edward Deegan. Deegan was murdered as he and Anthony Stathopoulos were about to break into a Chelsea finance company. Stathopoulos, also a target of the hit, escaped alive. Sever ${ }^{70}$ men were prosecuted for crimes including capital murder and conspiracy to commit murder. Among those found guilty were the "Salvati Four:" Joseph Salvati, Peter Limone, Louis Greco (also known as "Grieco"), and Henry Tameleo. All four were convicted of first-degree murder. Salvati received a life sentence, and the other three were sentenced to death.

The state's principal witness at trial was Joseph "The Animal" Barboza, also known as Joseph Baron. The FBI knew Barboza as a "professional assassin" with ties to the mob. ${ }^{171}$ In return for his cooperation, Barboza was allowed to plead guilty to two conspiracy charges, receive a sentence of probation, and enter the federal witness protection program. ${ }^{172}$ He testified that he accepted a Mob "contract" to carry out the killings from Peter Limone and conspired with the

168 The "Salvati Four" are Joseph Salvati, Louis Greco (see infra text accompanying note 212), Peter J. Limone (see supra text accompanying note 159), and Henry (Enrico) Tamaleo (see infra text accompanying note 231).

169 See Commonwealth v. Limone, 2001 WL 30494 (Mass. Super. Ct. Jan. 8, 2001); Commonwealth v. Salvati, 420 Mass. 499, 500 (1995); Defendant's Motion for a New Trial, Commonwealth v. Salvati, No. 32368-370 (Aug. 23, 1993); Grieco v. Meachum, 533 F.2d 713 (1st Cir. 1976); Commonwealth v. Cassesso, 360 Mass. 570 (1971); Commonwealth v. French, 357 Mass. 356 (1970); The FBI's Handling of Organized Crime Investigations in Boston: The Case of Joseph Salvati: Hearing Before the Committee on Government Reform, 107th Cong. (2002), available at http://www.house.gov/reform (last visited Mar. 27, 2002); Carey Goldberg, An Innocent Man Goes Free 33 Years After Conviction, N.Y. TIMES, Feb. 1, 2001, at A12; Ed Hayward, Board OKs Commutation of Salvati Life Sentence, Boston HERALD, Feb. 6, 1997, at 7 [hereinafter Hayward, Board]; Ed Hayward, Weld Seeks Commutation for 29-year Convict Salvati, BosTON HERALD, Dec. 19, 1996, at 26; J.M. Lawrence, Panel Slams Judge Over Wrongful Mob Conviction, Boston Herald, Feb. 15, 2002, at 1; Maggie Mulvihill et al., Special Report Follow-Up: Ex-agent asked to testify on FBI corruption, BOSTON HERALD, Apr. 12, 2001, at 1; Jonathan Wells \& Maggie Mulvihill, Hidden Truth; Hoover's FBI may have suppressed info on Mob hit, Boston HerALD, Dec. 21, 2000, at 1; see also John Cavicchi, Today, Would the Supreme Judicial Court of Massachusetts Have Granted Sacco and Vanzetti a New Trial Based on Current, Retroactively Applied Case Law?, 7 NaT'L ITAlian AM. B. Ass'N J. 33 (1999).

170 The seven included Joseph Barboza, who pleaded guilty to lesser charges on the first day of trial and gave evidence for the Commonwealth.

171 See STAFF OF HOUSE COMMISSION ON GOVERNMENTT REFORM, 107TH CONG., ITEMS UNDER SubPoena AND Their SignifiCANCE, available at http://www.reform.house.gov/bostondocs.htm (last visited Jan. 23, 2003).

172 Barboza was the first person placed in the federal witness protection program, in which he later committed murder. 
other defendants to accomplish the deed. Barboza's credibility was the main issue at trial. In convicting the four defendants named above, the jury rejected the defense contention that Barboza falsely incriminated them in order to protect his true accomplices in the murder.

After all the defendants lost their appeals, the Supreme Court's 1972 decision in Furman v. Georgia ${ }^{173}$ saved Limone, Greco, and Tameleo from the death penalty $;{ }^{174}$ they were given sentences of life without parole. ${ }^{175}$ Thereafter, several of the defendants sought new trials. They presented new evidence, including Barboza's affidavit recanting his testimony inculpating the Salvati Four ${ }^{176}$ and previously suppressed reports from informants to the police also indicating that Barboza and Stathopoulos had testified falsely at trial. ${ }^{177}$ The courts rejected these attempts to reopen the case. ${ }^{178}$

A stunning break in the case occurred in 1998, when the Department of Justice

173409 U.S. 902 (1972).

174 Although Massachusetts had death penalty statutes both before and after Furman, its last execution took place in 1947. Alan Rogers, "Success-At Long Last:" The Abolition of the Death Penalty in Massachusetts, 1928-1984, 22 B.C. THIRD WORLD L.J. 281, 30607 (2002). After that year, virtually all those sentenced to death had their sentences commuted by the governor. See Tom Canon, FIRST Degree Murder: THE POST CONVICTION EXPERIENCE IN MASSACHUSETTS 15 (1974) (stating that of forty-six persons sentenced to death between May 19, 1947, and January 1, 1973, one committed suicide, two received new trials and were acquitted, and the rest had their sentences commuted). Therefore, even before Furman was decided, the likelihood that Limone, Greco, and Tameleo would actually be executed was remote. Nonetheless, all of the Salvati Four, at various times, lived with the fear of capital punishment. For the history of the death penalty in Massachusetts, in addition to the sources cited immediately above, see COMmonwealth of MasSachusetts SPECIAL Committee Established for the PURPOSE of Investigating and Studying the Abolition of the Death Penalty in Capital CASES: REPORT AND RECOMMENDATIONS, H.R. 2575 (1959); Note, The Death Penalty in Massachusetts, 8 SUFFOLK U.L. REV. 632 (1974).

175 See Limone v. Mass., 408 U.S. 936 (1972).

176 In 1980, attorney F. Lee Bailey submitted an affidavit recounting Barboza's attempts to recant his testimony and Barboza's claim "that federal authorities 'coerced' him into changing his mind." Ralph Ranalli, Did FBI Get Help "Flipping" Mob Killer Barboza?, Boston Herald, Aug. 5, 1997, at 4.

177 Filed in support of Salvati's 1993 motion for a new trial were supporting affidavits from: (1) a former Chelsea police detective who investigated the Deegan murder and coauthored the allegedly suppressed police report that inculpated Barboza and Flemmi and, by implication, contradicted Barboza's trial testimony; (2) the former trial prosecutor in the Salvati Four case, who had no memory of having seen the exculpatory police report; and (3) defense attorney Joseph Balliro, who represented Tameleo at trial, who confirmed that he had not been given the exculpatory report. Rejecting the new trial motion, the courts found that the defense had access to information in the report which, in any event, was not directly exculpatory. Defense counsel continues to deny the accuracy of these findings. See telephone interview with attorney Victor Garo (Sept. 4, 2002).

178 See Salvati, 420 Mass. at 500; Cassesso, 360 Mass. at 579. 
appointed a task force to investigate corruption in the Boston office of the FBI. In December 2000, the Task Force released previously secret FBI records showing that mob boss Raymond Patriarca, and not Limone, had ordered Deegan's murder. They also showed that the FBI had known in advance that the killing would take place and knew immediately afterwards that Barboza and his "partner" at the time, Vincent James Flemmi-and none of the Salvati Four-had participated in the killing. ${ }^{179}$ It thus appeared that to protect their own informants, FBI agents had knowingly helped to frame four innocent men for capital murder. ${ }^{180}$ Afterwards, they allegedly intervened to oppose defense efforts to obtain sentence commutations. ${ }^{181}$

In January 2001, a Superior Court judge heard this evidence on Limone's motion for a new trial. The court also considered a 1976 affidavit from Barboza's lawyer, first submitted in 1990, stating that Barboza admitted falsely testifying against Limone. Lawyers for two other participants in the killing also announced that their former clients had said that the Salvati Four were innocent. ${ }^{182}$ On January 8, 2001, the court granted Limone's motion. After thirty-three years in prison, he was free. Two weeks later, the same judge threw out Salvati's conviction. ${ }^{183}$ Salvati was already free, having won the governor's commutation of his sentence and release on parole in $1997 .{ }^{184}$ Salvati had spent thirty years in

179 These FBI records surfaced in a federal prosecution, see Limone, 2001 WL 30494, at *4. Vincent Flemmi's brother, Stephen, was an FBI informant, and Vincent Flemmi also became an FBI informant around that time. Stephen Flemmi was not charged in the Deegan murder.

${ }^{180}$ However, former U.S. Attorney and current federal Judge Edward F. Harrington maintains that Barboza testified truthfully in the Salvati case. See Lawrence, supra note 169. Also, FBI officials claim that they shared at least some of the exculpatory reports from their informants with Chelsea police. It is not clear whether the FBI or the Chelsea police also informed the Suffolk County District Attorney's office. See Shelley Murphy, FBI Says Documents Clear it of Wrongdoing in '65 Case, Boston GlobE, Feb. 15, 2001, at B5. Local prosecutors deny having been informed. See J.M. Lawrence, FBI Claims Police Got Evidence in ' 65 Mob Hit, BOSTON HERALD, Feb. 15, 2001, at 5. The former trial prosecutor, now a prominent Boston defense attorney, denies having known of these reports. Wells \& Mulvihill, supra note 169.

${ }^{181}$ See Edmund H. Mahony, Calling FBI to Account; Did Bay State Agents Have Own Agenda?, HaRtFord Courant, June 3, 2001, at A1; Hearings on The FBI's Handling of Organized Crime Investigations in Boston, supra note 169.

182 Jonathan Wells, Another Day in Court; DA to Seek New Trials for Convicts in Mob Hit, Boston Herald, Jan. 4, 2001, at 5.

${ }^{183}$ J.M. Lawrence, Second Man Exonerated in 1965 Mob Killing Case, Boston HERALD, Jan. 19, 2001, at 2.

${ }^{184}$ Carolyn Thompson, Salvati Released, Asserts Innocence, PATRIOT LEDGER, Mar. 21,1997 , at 5 . The preceding media campaign for Salvati's release is described in Jennifer R. Wilder, Freeing the Innocent, B.U. SCH. OF L. ALUMNI MAG., Spring 1997, at 4. Governor Weld's decision to commute Salvati's sentence, after having rejected an official recommendation that he do so in 1993, was supported unanimously by the Governor's Council. Weld explicitly disavowed any opinion that Salvati was innocent, but 
prison. Judicial vindication came too late for Tameleo and Greco; both died in prison. ${ }^{185}$

Recognizing the power of the new exculpatory evidence, the prosecution joined both Limone's and Salvati's motions for new trials. Prosecutors subsequently announced that they would not retry the two men because they did "not now have a good faith basis - legally or ethically - to proceed with any further prosecution" against them. ${ }^{186}$ Although the prosecutors did not explicitly concede the innocence of the Salvati Four, the District Attorney acknowledged that "a great wrong was committed." 187

In the aftermath of Limone's and Salvati's release, a Congressional committee launched an investigation into the FBI's use of mob informants in Boston. ${ }^{188}$ In hearings, committee members apologized to Salvati and declared their belief in his innocence. ${ }^{189}$ Subsequently, lawyers representing Limone and the families of Greco and Tameleo sued federal and state authorities for $\$ 375$ million. ${ }^{190} \mathrm{Mr}$. Salvati has filed notice of his intention to sue the FBI for $\$ 300$ million for false imprisonment. ${ }^{191}$

Comment: Despite the absence of any explicit judicial or executive determination that Salvati, Greco, Tameleo, and Limone were innocent of any involvement in Deegan's death, the evidence points very strongly to that conclusion. But for the fortuitous timing of the Supreme Court's decision in

some councilors expressed that belief. See Don Aucoin, Dead Convict's Lawyer Hits Weld on Sentence Commutation, Boston GlOBE, Jan. 4, 1997, at B6; Hayward, Board, supra note 169.

185 Tameleo died in 1985, Greco in 1995. See J.M. Lawrence, Ex-wife Recounts Plight of Wrongfully Imprisoned Man, Boston HERALD, Jan. 9, 2001, at 4 (discussing Greco). See also infra Part III, Section C (entries for Greco and Tameleo).

186 J.M. Lawrence, Men Jailed Wrongly in Mob Slaying Clear Final Hurdle, BostoN HERALD, Jan. 31, 2001, at 5.

187 See Goldberg, supra note 169.

188 See FBI Corruption in New England: Chairman Burton Introduces Legislation to Rename the J. Edgar Hoover Building: Hearing Before the Committee on Government Reform, 107th Cong. (2002), available at http://www.house.gov/reform (last visited Mar. $27,2002)$.

${ }^{189}$ See Hearing on The FBI's Handling of Organized Crime Investigations in Boston, supra note 169. Former FBI Agent H. Paul Rico, who originally investigated the Deegan murder case also conceded his belief in Salvati's innocence. See Ken Maguire, Former FBI Agent Says He Believes Salvati Innocent, AssocIATED Press, May 3, 2001. In testimony before another Congressional committee, FBI Director Louis Freeh also implied that the FBI had contributed to "sending an innocent man to prison." Denise Lavoie, FBI Director Calls Salvati Case a 'Sad Chapter' in FBI History, Associated PrEss, May 16, 2001.

190 Cambanis, supra note 160 (announcing joint suit by Mr. Limone and representatives of the estates of Enrico Tameleo and Louis Greco); Fox Butterfield, Hoover's FBI and the Mafia: Case of Bad Bedfellows Grows, N.Y. TIMES, Aug. 25, 2002, at 12.

191 Butterfield, supra note 190. 
Furman, Massachusetts might have executed three innocent men.192

\section{Peter Vaughn, Suffolk County ${ }^{193}$}

On the afternoon of Thursday, January 6,1983, two men held up a Star Market grocery store in Boston at gunpoint. Because employees of a neighboring Sears Roebuck regularly cashed their paychecks at the Market on Thursdays, the robbers escaped with over $\$ 38,000$. In the ensuing weeks, three Star Market employees identified Peter Vaughn, a black male, from photo arrays and/or from a group of mostly black defendants standing in a courtroom dock, as one of the robbers. At trial, the Commonwealth case was based entirely on the testimony of those three eyewitnesses. For the defense, one of Vaughn's friends testified that at the time of the robbery Vaughn was picking her up from work. The defense also introduced photographs of the robber taken by Star Market security cameras, as well as photographs of an identically dressed person of the same size, build and complexion, robbing the same market, also on a Thursday afternoon, two months later. At the latter time, Vaughn was in jail on an unrelated charge. In both robberies, the robber yelled "Time!" The defense argued, therefore, that the same man had robbed the market on both dates, and since Vaughn could not have robbed it on the second date, he did not rob it on the first. The trial court denied Vaughn's motion for a directed verdict of acquittal, and the jury found him guilty. On direct appeal, after viewing the photographs from both robberies, the Appeals Court reversed Vaughn's conviction and entered a verdict of acquittal. In doing so, the Court found that the "only rational explanation" for the evidence was that "the same person was involved in both robberies" and that Vaughn could not have committed the second one.

Following Vaughn's release, several private compensation bills were filed on his behalf in the state legislature without success. ${ }^{194}$

Comment: Some might view the Appeals Court opinion as implying official recognition of Vaughn's factual innocence. Regardless, the circumstances attending his release raise strong doubts about his factual guilt. ${ }^{195}$

192 See Furman, 409 U.S. 902; but see supra note 174.

193 See Commonwealth v. Vaughn, 23 Mass. App. Ct. 40 (1986); Appellate Briefs and Record, Vaughn, 23 Mass. App. Ct. 20; Brian MacQuarrie, What Are Lost Years Worth? Brockton Man Wants State to Pay for Wrongful Conviction, Boston GloBE, Sept. 15, 1999, at B1.

${ }^{194}$ Bruce Mohl, Wronged Ex-Inmate Asks for $\$ 950,000$ Leaster Tells Legislators "Best

Years" Were Lost, Boston GloBe, Mar. 25, 1999, at 15.

195 The Appeals Court said:

The man photographed in the second robbery appears to us to be the same person as the one in the first robbery. Although we could be absolutely certain only if we could see the facial features clearly, the accumulation of coincidences between the two incidents is remarkable.... The only rational explanation for the coincidences is that the same person was involved in both robberies.

Vaughn, 23 Mass. App. Ct. at 43. 


\section{Kenneth Waters, Middlesex County ${ }^{196}$}

In the early morning hours on May 21, 1980, Katharina Brow was stabbed to death in her Ayer home. Her purse, cash, and jewelry were missing. The police suspected Kenneth Waters, who lived near the victim and had broken into her home when he was a boy. Waters worked as a cook at the diner where Brow frequently ate and where she had spoken openly about the cash she carried with her. The police, however, lacked sufficient evidence to proceed. For two years the crime remained unsolved until police received information that Waters, while drunk, had admitted killing Brow to two former girlfriends. ${ }^{197}$ A third witness, who had worked with Waters, told police that he had told her before the murder that he hated the victim. She also said that three weeks after the murder, Waters had sold her a ring that she had earlier given to Brow. ${ }^{198}$ Furthermore, bloodstains allegedly left by the perpetrator at the scene were type " $O$," the same as Waters' blood. The police had inspected Waters for injuries a few hours after the murder and found none. Nevertheless, Waters was charged with the killing. Two years after the crime, unable to establish his alibi, he was convicted of firstdegree murder and armed robbery and sentenced to life in prison.

Waters always maintained his innocence. His sister, Betty Anne Waters, vowed to become a lawyer and win his freedom. A mother of two who lacked a high school diploma, she managed to put herself through college and law school. As an attorney, she sought and found in the courthouse basement a box containing the blood-stained exhibits from her brother's trial. In April 2000, the court approved an agreement between the District Attorney's office and the defense to

196 See Commonwealth v. Waters, 399 Mass. 708 (1987); Appellate Briefs and Record, Waters, 399 Mass. 708; Defendant's Unopposed Emergency Motion for New Trial (Mar. 14, 2001); talk by attorney Betty Anne Waters at the offices of Testa Hurwitz \& Thibeault in Boston (Mar. 5, 2002); Christopher Dawson, Commonwealth v. Kenneth Waters (2001) (unpublished student paper, on file with the author); Man Pleads Innocent to 1980 Slaying in Ayer, Boston Globe, Nov. 19, 1982, at 21; Bill Hewitt \& Jennifer Longley, Sister of Mercy, PeOPle, Apr. 9, 2001, at 174; Prosecutors Drop Plan to Retry Man Freed by DNA Evidence, WORCESTER TELEGRAM AND GAZETTE, June 27, 2001, at A2; Farah Stockman \& Ellen Barry, A Tragic End to Newly Won Freedom: Fall Kills R.I. Man Cleared in Slaying, Boston GloBE, Sept. 20, 2001, at B1; Farah Stockman \& Mac Daniel, After 18 Years in Prison, "It's Great to be Free" Ex-Inmate Savors the World Outside, BOSTON GLOBE, Mar. 16, 2001, at B1.

197 Neither former girlfriend came forward voluntarily to the police. The first, Brenda Marsh, told no one of Waters' admission for two years. Even then, her current boyfriend, not she, informed the police. The police allegedly threatened Marsh with loss of her children if she did not cooperate with them. The police originally contacted Waters' second former girlfriend, Roseanna Perry. After trial, Perry reportedly signed a thirtyfive page affidavit recanting her trial testimony and later retracted the recantation. Talk by attorney Betty Anne Waters at the offices Testa Hurwitz \& Thibeault in Boston (Mar. 5, 2002).

198 Trial testimony seriously impugned this evidence. See Dawson, supra note 196, at 34-35 (citing trial transcripts). 
conduct DNA testing. The tests proved that Waters was not the donor of any of the biological evidence found at the crime scene. ${ }^{199}$ They did reveal the DNA of an unidentified male donor. Prosecutors agreed not to oppose Waters' motion for a new trial, which was granted in March 2001. Although prosecutors would not concede Waters' innocence, they declined to retry him for the reason that there was "insufficient evidence to proceed." 200 After eighteen years in prison, Waters was free. Tragically, however, Mr. Waters died from an accidental fall six months later. ${ }^{201}$

Comment: Although police investigators explained the DNA test results by suggesting that Waters committed the crime with an accomplice, no evidence in the twenty-one year history of the case appears to corroborate that theory. The major evidence of Waters' guilt consists of drunken admissions he allegedly made to two former girlfriends, who Waters claimed lied in response to police coercion. While the circumstances of this case do not prove Waters' factual innocence, they do raise strong doubts about his guilt.

We now turn to the final Section in this Part, in which I consider innocence claims on behalf of prisoners whose convictions were never vacated.

\section{Persons Who Were Neither Officially Exonerated Nor Whose Convictions Were Vacated But As To Whose Factual Guilt Strong Doubt Exists}

In this Section, I describe six cases of persons convicted in Massachusetts whose convictions were never vacated. All of these persons were either executed or died in prison.

199 Laboratory testing before trial had excluded Waters as the donor of hairs, not from the victim, found on the victim, on the murder weapon, and elsewhere at the scene. Id. at 9-19 (citing trial transcripts).

200 Prosecutors Drop Plan, supra note 196. Police reportedly theorized that Waters had been present as an accomplice when the perpetrator left blood at the scene. Hewitt \& Longley, supra note 196.

201 Stockman \& Barry, supra note 196. 
Table C

Persons Who Were Neither Officially Exonerated Nor Whose Convictions Were Vacated But As To Whose Factual Guilt Strong Doubts Exist

\begin{tabular}{|c|c|c|c|c|}
\hline Name & Convicted & Released & Crime & Compensation \\
\hline Daley & 1806 & Executed & Murder I & - \\
\hline Greco & 1968 & Died in Prison & Murder I & Suit pending \\
\hline Halligan & 1806 & Executed & Murder I & - \\
\hline O'Neil & 1897 & Executed & Murder I & - \\
\hline Tameleo & 1968 & Died in Prison & Murder I & Suit pending \\
\hline Vanzetti & 1921 & Executed & Murder I & - \\
\hline
\end{tabular}

\section{Dominic Daley (also known as "Daly"), Hampshire County ${ }^{202}$}

In 1806, two Irish immigrant laborers, Dominic Daley and James Halligan were convicted and hung for the murder of Marcus Lyon, a Wilbraham farmer. The conviction rested primarily on eyewitness testimony placing the two defendants in possession of the victim's horse near the scene of the crime shortly after it occurred. ${ }^{203}$ Defense counsel, having been appointed only one day before the trial, presented no defense witnesses. ${ }^{204}$ The trial, deliberations, and verdict took place on the same day. Some contended that the men were innocent victims of "anti-Catholic fervor" prevalent at the time. ${ }^{205}$ Reportedly, "the uncle of the

202 See Report of the Trial of Dominic Daley and James Halligan for the

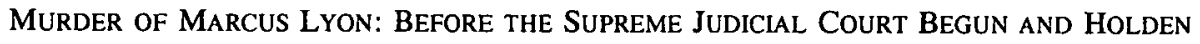
AT NORTHAMPTON (T.M. Pomroy ed., 1806); Robert Sullivan, The Murder Trial of Halligan and Daley-Northampton, Massachusetts, 1806, 49 MASs. L.Q. 211 (1964); Ken Armstrong \& Steve Mills, Fatal Judgment: In the U.S., 2nd Thoughts on Troubled Death Record, CHI. TRIB., Dec. 31, 2000, § 2, at 1; Pardon for Executed Men?, Boston GlobE, Feb. 23, 1984, at 64; Joe Quinlan, Governor's Pardon 178 Years later in Holyoke, Boston Globe, Mar. 19, 1984, at 16; Irene Sege, Justice sought 176 Years After 2 Men Hanged, Boston GLOBE, June 13, 1982, at 27.

203 In addition, the prosecution stressed the fact that the defendants walked at a quicker pace after the day of the murder than they had walked on the days preceding it. Sullivan, supra note 202, at 218. The jury also heard testimony that an Irish laborer in New York, not identified as either of the defendants, had previously purchased two pistols resembling the murder weapons and that the defendants, when arrested, had bank bills identical to those previously possessed by the victim. The trial judge instructed the jury in closing to disregard both of these pieces of evidence as too remote to have relevance. REPORT OF THE TRIAL, supra note 202 , at 83.

204 Sullivan, supra note 202, at 217, 219. As Sullivan points out, the trial took place at a time when criminal defendants were incompetent to testify. Id.

${ }^{205}$ Reportedly, "the priest who traveled from Boston at the prisoners' request [to celebrate Mass in their cell before they were hung] had to sleep at the jail because no local innkeeper would give shelter to a "Papist." Sege, supra note 202. Daley and Halligan were made the subject of a play entitled "They're Irish! They're Catholic! They're Guilty." Pardon for Executed Men, supra note 202. Reportedly, a crowd of 15,000 came 
key prosecution witness subsequently confessed to the crime on his deathbed." 206 After the failure of earlier efforts to gain official exoneration of Daley and Halligan, ${ }^{207}$ Governor Michael Dukakis issued a proclamation in March 1984, stating that:

the historical record shows that religious prejudice and ethnic intolerance played a significant role in their arrest and trial, which resulted in the denial of their rights of due process and a miscarriage of justice.... [A]ny stigma and disgrace associated with their names as a result of their conviction is hereby removed. ${ }^{208}$

Comment: Governor Dukakis's proclamation hardly amounts to an official exoneration. Review of the trial record and the surrounding circumstances, however, gives rise to a strong doubt as to the defendants' factual guilt. The prosecution case rested primarily on weak ${ }^{209}$ eyewitness identification evidence. The other circumstances attending their conviction fit a pattern ${ }^{10}$ common to many wrongful convictions; the defendants were poor, they came from a despised religious minority, and, in a climate of intense community passion, ${ }^{211}$ they were accused of brutally killing an established citizen.

to witness the hanging. Sullivan, supra note 202, at 221.

206 Quinlan, supra note 202; Sege, supra note 202; Sullivan, supra note 202, at 223-24.

207 In 1982, the Massachusetts House of Representatives adopted a resolution urging Governor King to grant a posthumous pardon. Sege, supra note 202. However, Governor King left office without granting the pardon.

${ }^{208}$ Quinlan, supra note 202. Governor Dukakis issued a similar proclamation in 1977 with respect to the 1927 executions of Nicola Sacco and Bartolomeo Vanzetti, which provoked the Massachusetts Senate to debate a resolution critical of the Governor. See infra text accompanying note 260 .

209 The chief eyewitness was a thirteen year-old boy who claimed to have seen the perpetrators briefly and from a distance and who first identified Daley as one of the perpetrators under suggestive circumstances (Daley and Halligan were the only persons present in irons). Sullivan, supra note 202, at 218.

${ }^{210}$ See Diane L. Martin, The Police Role in Wrongful Convictions: An International Comparative Study, in Wrongly CONVICTED: PERSPECTIVES ON FAILED Justice 83 (John A. Humphrey \& Saundra D. Westervelt eds., 2001) (stating that wrongful convictions most often occur when the police are under significant pressure to get a conviction, the accused is "a marginalized outsider," and/or the case for guilt rests on inherently unreliable evidence).

211 The Governor offered a reward of five hundred dollars for the detection of the murderers. Sullivan, supra note 202, at 215. 


\section{Louis Greco (also known as "Grieco"), Suffolk County ${ }^{212}$}

One of the "Salvati Four," Louis Greco died in a prison hospital ward in December $1995,{ }^{213}$ at age seventy-eight, after being incarcerated for twenty-eight years. For the facts of his case, and comments, see entry for Joseph Salvati, in Section B, above. ${ }^{214}$

Like others of the "Salvati Four," Greco proclaimed his innocence throughout his imprisonment. He reportedly "passed three polygraph [tests], including one administered on a national television show in 1983. ${ }^{\text {.115 }}$ Barboza's former lawyer, F. Lee Bailey, stated that Barboza had admitted Greco's innocence to him after the trial. ${ }^{216}$ According to press reports:

The [parole] board voted twice to recommend commutation for Greco, once in 1985 and again in 1987, when his health was deteriorating. Greco underwent treatment for colon cancer, diabetes, and a heart condition. But Governors Michael Dukakis and William F. Weld refused to commute Greco's sentence, citing the seriousness of the crime. ${ }^{217}$

Two weeks before Greco's death [in 1995], John Cavicchi [his lawyer] made a last-ditch effort to win a commutation and got Greco's signature on an emergency petition. "It was just a scrawl and Weld still wouldn't let him out," Cavicchi said. ${ }^{218}$

At the time of this writing, Greco's attorney was pursuing measures to have Greco exonerated. ${ }^{219}$ Meanwhile, Greco's estate has filed a civil suit against the state and federal governments. ${ }^{220}$

212 See supra note 169; Greco v. Dickhaut, No. 82-3422, 1983 U.S. LEXIS 15452 (D. Mass. July 14, 1983); Commonwealth v. Greco, 384 Mass. 799 (1981); Kevin Cullen, To Die a Free Man Inmate, 74 and Sick, Wants His Life Sentence Commuted, Boston GloBE, May 28, 1991, at 13.

${ }^{213}$ Shelley Murphy, FBI's Role at Issue in Vain Search for Freedom, Boston GLoBE, July 16, 2001, at B1.

214 See supra at text accompanying note 169.

215 Murphy, supra note 213.

216 Cullen, supra note 212.

217 Murphy, supra note 213. Apparently, one of Greco's legs was amputated in prison, precipitating the suicide of Greco's oldest son. J.M. Lawrence, Inmates' Families Did Time, Too; Limone Kids Feel Robbed of Life With Dad, Boston Herald, Dec. 23, 2000, at 6 .

218 Lawrence, supra note 217.

219 In November 2001, attorney John Cavicchi applied to the Parole Board to pardon Greco posthumously. Lawyer Calls for Posthumous Pardon, Mass. L.W., Nov. 19, 2001, at 2. Because, however, no precedent exists for posthumous pardons in Massachusetts, he plans instead to seek relief in the form of an executive proclamation, as well as a legislative resolution. Email from John Cavicchi (Aug. 3, 2002) (on file with author).

${ }^{220}$ Cambanis, supra note 160 (announcing joint suit by Mr. Limone and representatives of the estates of Enrico Tameleo and Louis Greco). 


\section{James Halligan, Hampshire County ${ }^{221}$}

An Irish immigrant, James Halligan was convicted and executed in 1806 for the murder of Marcus Lyon, a farmer. For the facts of his case, and comment, see the entry for his alleged accomplice, Dominic Daley, above.

\section{John O'Neil, Franklin County ${ }^{222}$}

Hattie McCloud, thirty-six, an attractive widow from a prominent family in Buckland, near Shelburne Falls, was attacked and strangled along a country road on January 8, 1897. Her frozen body was discovered in an adjacent field the next morning. A ten dollar bill, a five dollar bill, and sixty-seven cents in silver were missing from her purse. Police surmised that some "drunken bum" must have committed the crime. Three days later, they arrested Jack O'Neil,

a jobless lad living with his mother and five of his brothers and sisters a short distance from the home of the victim ..... O'Neil was painted as a ne'er -do-well who spent nearly all of his time drinking and in talking of women in an ungallant fashion. He was described as one of a gang that preyed upon single travelers and robbed them for money to buy liquor. ${ }^{223}$

Local opinion was divided between those who regarded O'Neil as a dangerous drunk, and "another group claiming he was being persecuted by police for racial reasons." 224 O'Neil was tried and convicted for capital murder. No testimony placed O'Neil at or near the murder scene. The prosecution, however, showed that O'Neil had no money until an hour before the murder, yet within two hours afterwards he had the same amount, in bills and coins of the same denominations, as was missing from the victim's purse. There was testimony, furthermore, "that he gave false and contradictory accounts" of how he obtained the money.2 And, in addition to "other circumstantial evidence tending to connect [him] with the crime," the prosecution produced a fellow prisoner from the jail who testified that O'Neil had "admitted that he had ten dollars of [McCloud's] money, ${ }^{1226}$ which he claimed he got from her killer.

Sentenced to die by hanging, O'Neil was executed on January 7, 1898. ${ }^{227}$ A newspaper account written fifty years later concludes the tale:

221 See supra note 202.

222 See Commonwealth v. O'Neil, 169 Mass. 394 (1897); BEDAU, supra note 90, at 505; Ehrmann, supra note 106; Lawrence R. Goldberg, Hang Innocent Man in Slaying, BOSTON GloBE, June 26, 1950, at 13.

223 Goldberg, supra note 222.

${ }^{224}$ Id. The sources available to me do not specify O'Neil's race.

225 O'Neil, 169 Mass. at 394.

226 Id.

${ }^{227}$ O'Neil was the last person executed by hanging in Massachusetts before the Commonwealth replaced the gallows with electrocution in 1900. BEDAU, supra note 90, at 505 . 
O'Neil went to the gallows vigorously denying the killing and claiming that he was the dupe of racial bigotry .... "I shall meet death like a man and I hope those who see me hanged will live to see the day when it is proved I am innocent, and it will be, some time."

A few months later, support of O'Neil's claim came from a dying Shelburne Falls soldier, fighting the Spaniards in Cuba as a member of the old Sixth Massachusetts Volunteer Militia. The soldier, aware that he was going to die, confessed to the murder and cleared O'Neil.

Eddie Collins, an ace newspaper reporter, covering the Cuban action as a war correspondent for the old Boston Journal, interviewed the soldier and made arrangements for a signed confession .... Before the written confession could be obtained to back up the oral one, the soldier succumbed - and shortly afterwards, Collins died on the field. ${ }^{228}$

Comment: Whether "strong doubt" exists as to O'Neil's factual guilt is arguable. Unlike almost every other case discussed in this Part, O'Neil's claim of innocence rests entirely on hearsay, unsupported by official action of any sort. On the other hand, just as in the case of Daley and Halligan, discussed above, the circumstances attending his conviction fit a pattern ${ }^{22}$ common to many wrongful convictions: the defendant was poor and came from a minority racial group; he was accused of brutally killing a white woman from a locally prominent family; aside from O'Neil's alleged admission to a fellow prisoner, which must be regarded skeptically, ${ }^{230}$ the evidence of guilt was entirely circumstantial. In light of these circumstances, the dying soldier's confession to a reputable reporter, on the heels of O'Neil's own end-of-life protestations of innocence, leads me to include this case in the "innocent" category.

\section{Henry (Enrico) Tameleo, Suffolk County ${ }^{231}$}

One of the "Salvati Four," Henry Tameleo died in prison in 1985 at the age of eighty-four, after seventeen years of imprisonment. ${ }^{232}$ For the facts of his case, and comments, see entry for Joseph Salvati, above. ${ }^{233}$ Lawyers for Tameleo's estate have filed suit for damages against federal and state authorities. ${ }^{234}$

${ }^{228}$ Goldberg, supra note 222.

229 See Martin, supra note 210.

${ }^{230}$ See Clifford S. Zimmerman, From the Jailhouse to the Courthouse: The Role of Informants in Wrongful Convictions, in WRONGLY CONVICTED, supra note 210, at 83.

231 See supra text accompanying note 169.

${ }^{232}$ Murphy, supra note 213.

233 See supra text accompanying note 169.

${ }^{234}$ Cambanis, supra note 160 (announcing joint suit by Mr. Limone and representatives of the estates of Enrico Tameleo and Louis Greco). 


\section{Bartolomeo Vanzetti, Norfolk County ${ }^{235}$}

On the afternoon of April 15, 1920, five or six men in a touring car robbed two employees of the Slater \& Morrill shoe company in South Braintree. The robbers shot and killed Parmenter, the paymaster, and Berardelli, his guard. They escaped with the $\$ 15,000$ company payroll. Three weeks later, two anarchists, Nicola Sacco and Bartolomeo Vanzetti, were arrested after their aborted attempt to collect a touring car, which police suspected of being used in the robbery, from storage. When stopped by the police, both men were carrying loaded revolvers and lied to the police about their background and activities. In proceedings that attracted enormous international attention and controversy, Sacco and Vanzetti were tried jointly for the double capital murder. In July 1921, they were convicted. Six years later, after rejection of several new trial motions, loss of their appeals, and review of their case by a special advisory committee appointed by the Governor, ${ }^{236}$ Sacco and Vanzetti were executed.

The government's theory at trial was that Sacco was the shooter and Vanzetti one of his accomplices. ${ }^{237}$ The evidence submitted against Sacco included: eyewitnesses who identified him as the perpetrator; his possession, when arrested, of a Colt revolver that the prosecution claimed fired the fatal bullet at Berardelli, and of shells similar to those found near the body; a cap found at the scene, said to have been worn by the shooter, and identified as Sacco's; and "consciousness of guilt," manifested by Sacco's admitted lies to the police when arrested. The evidence against Vanzetti was weaker. It included: eyewitness testimony placing him in the company of the robbers before and after the crime; evidence of his lies to the police when arrested, suggesting consciousness of guilt; and firearms evidence. The latter consisted mainly of evidence tending to prove that the .38 caliber revolver found on Vanzetti when he was arrested had been taken at the scene from the murdered guard, Berardelli. In defense, Sacco and Vanzetti impeached the government's eyewitness, firearms, and ballistics evidence; they explained that their admitted lies to the police had been motivated by a fear that they would be persecuted for the peaceful but unpopular anarchist activities in

235 The literature on Sacco and Vanzetti is voluminous. In preparing this account, I have been able to examine only a few sources. See Commonwealth v. Sacco, 255 Mass. 369 (1926); EXECUTIVE DEPARTMENT OF MASSACHUSETTS, REPORT TO THE GOVERNOR IN the Matter of SaCCo and Vanzetti (1977); Felix Frankfurter, The Case of SaCCo AND VANZETTI (University Library 1961) (1927); FranCIS RuSSELL, SACCO \& VANZETTI: The Case Resolved (1986); William Young \& David E. Kaiser, Postmortem: New Evidence In the Case of Sacco and Vanzetti (1985); Paul Avrich, Sacco and Vanzetti: The Case Resolved, The New RePublic, Apr. 7, 1986, at 40. See also Transcript of the Record of the Trial of Nicola Sacco and Barolomeo Vanzetti in the Courts of Massachusetts and Subsequent Proceedings 1920-27 (1969).

236 The Governor's Advisory Committee was chaired by Harvard University President Lowell and known popularly as the "Lowell Committee." See RusSELL, supra note 235, at 196-202 (describing the work of the Committee).

237 The facts that follow are drawn from the Supreme Judicial Court's opinion in Sacco, 255 Mass. 369. 
which they claimed to have been engaged when arrested..$^{238}$ In addition, each testified to an alibi and produced a number of supporting witnesses.

Controversy over the Sacco and Vanzetti case continues to this day. Critics of the convictions have pointed to a number of weaknesses in the state's case, such as the failure to trace any of the stolen money to the defendants or to identify any of the other perpetrators. ${ }^{239}$ As Harvard Law School Professor Edmund Morgan noted, the state's identification testimony was "weak and unconvincing. ${ }^{240}$ Eyewitnesses for the prosecution had not only been subjected to suggestive identifications, ${ }^{241}$ but experienced "improved" memories over time ${ }^{242}$ A large number of witnesses saw various stages of the daylight robbery, and yet, "[o]ver 75 percent of those having an opportunity to view the bandits before, during, or immediately after the crime denied having seen Sacco or Vanzetti. ${ }^{243}$ The government suppressed the identity of at least one of those witnesses. ${ }^{244}$ Critics have also attacked the state's firearms and ballistics evidence, ${ }^{245}$ the prosecution's deliberate introduction of misleading testimony, ${ }^{246}$ the unfair exploitation of the defendants' political radicalism, ${ }^{247}$ the tendency of the trial judge - whose expressions of prejudice against the defendants off the bench have been well

238 See, e.g., RUSSELL, supra note 235, at 102-06; YOUNG \& KAISER, supra note 235, at 70-84.

239 Morgan, Book Review, The Untried Case, 47 HaRv. L. REV. 538, 540 (1934) (reviewing Herbert B. Ehrmann, The SaCco-Vanzetti Case and the Morelli Gang (1934)).

240 Morgan, supra note 239, at 540. For detailed consideration of the eyewitness testimony, see FRANKFURTER, supra note 235, at 11-34 and YOUNG \& KAISER, supra note 235 , at $46-63$.

241 See RePORT to the GOVERNOR IN THE MATTER OF SACCO AND VANZETTI, supra note 235, at 23; FRANKFURTER, supra note 235, at 31-32.

242 See YOUNG \& KAISER, supra note 235 , at 46-63.

243 Id. at 62.

244 REPORT to the Governor In the MATter of SACCo AND VANZETTI, supra note 235 , at 24 (identity of eyewitness Gould suppressed); Morgan, supra note 239, at 541 (identities of two unidentified witnesses suppressed). The government also suppressed other exculpatory evidence, such as the fact that a tear in the lining of the cap found at the scene was caused by the police rather than, as argued by the prosecution, by Sacco's hanging it on a nail at work. Id. at 540-41.

245 See YOUNG \& KAISER, supra note 235, at 85-122 (claiming, inter alia, that the allegedly "fatal" bullet fired by Sacco's gun was fraudulently substituted for the actual bullet removed from Beradelli's corpse); Morgan, supra note 239, at 540; James E. Starrs, Once More Unto the Breech: Firearms Evidence in the Sacco and Vanzetti Case Revisited: Part I, 31 J. FoRENSIC SCI. 630, 640 (1986) (two-part article, continuing on page 1050, concluding that Sacco was probably guilty and that the firearms evidence against Vanzetti was "woefully weak and patently insufficient to support a verdict of guilty against him").

246 See FrANKFuRTER, supra note 235, at 76-79; YouNG \& KAISER, supra note 235, at 116; Morgan, supra note 239, at 541 (expert testimony by Captain Proctor).

247 See RePORT to the Governor In the MAtrer of SACCO AND VANZETTI, supra note 235, at 22-28; Morgan, supra note 239, at 541. 
established $\mathrm{d}^{248}$ - to exercise his discretion consistently in favor of the government, ${ }^{249}$ and a critical imbalance between the capable, aggressive prosecutor and "bungling" defense counsel $2^{250}$ Finally, critics have accused the FBI of playing a key role in framing the two radicals for a crime of which they were innocent. ${ }^{251}$

Even among supporters of the verdicts, the case against Vanzetti has been regarded as weaker than that against Sacco. ${ }^{252}$ With his long black moustache, Vanzetti was a man of distinctive appearance. Yet, the eyewitness testimony against him was particularly weak. ${ }^{253}$ Also, as Professor Felix Frankfurter wrote, his alibi "was overwhelming. Thirty-one eyewitnesses testified positively that not one of the men that they saw in the murder car was Vanzetti. Thirteen witnesses either testified directly that Vanzetti was in Plymouth selling fish on the day of the murder, or furnished corroboration of such testimony."254 The case for Vanzetti's innocence was strengthened in 1985 by the publication of a new study. ${ }^{255}$ The only physical evidence against Vanzetti was the .38 caliber revolver found in his possession, which the prosecution argued belonged to the victim, Berardelli. But law enforcement files released by the state police in 1977 show that police had an investigator's report that suggested that the guns were different. ${ }^{256}$ The prosecution never disclosed this exculpatory evidence to the defense. ${ }^{257}$ Efforts by supporters of Sacco and Vanzetti to win official

248 See REPORT TO THE GOVERNOR IN THE MATTER OF SACCO AND VANZETTI, supra note 235, at 29-31; YOUNG \& KAISER, supra note 235, at 6.

${ }^{249}$ See Morgan, supra note 239, at 541.

250 See id.

251 See, e.g., RUSSELL, supra note 235, at 173-82; YOUNG \& KAISER, supra note 235, at 124-33.

252 As Harvard President Lowell, Chairman of the Lowell Committee, acknowledged, the evidence against Vanzetti was entirely circumstantial. The preliminary drafts of his Committee Report declared: "On the whole, we are of the opinion, beyond reasonable doubt, that Vanzetti was also guilty, though with much less assurance than in the case of Sacco." The last clause was stricken from the final draft. RUSSELL, supra note 234, at 201. Francis Russell, a key spokesman for the view that Sacco and Vanzetti received a fair trial, has concluded that Sacco was guilty but Vanzetti was not. Id. at 6 .

253 "Of fourteen eyewitnesses to the crime who viewed Vanzetti [after his arrest], thirteen stated categorically that they had never seen him before in their lives." Young \& KAISER, supra note 235, at 57-58. See generally FRANKFURTER, supra note 235, at 25-34; YOUNG \& KAISER, supra note 235, at 25-34.

${ }^{254}$ FRANKFURTER, supra note 235, at 30.

25s See Young \& KAISER, supra note 235, at 85-122.

${ }^{256}$ The report might have been taken to prove that Berardelli's revolver was a .32 caliber with a different serial number than Vanzetti's. YOUNG \& KAISER, supra note 235, at 89 .

257 Id. at 90. Francis Russell disputes that the .32 caliber revolver was indeed the one possessed by Berardelli but does not appear to dispute the failure to disclose the exculpatory report to the defense. See Russell's reply following David E. Kaiser, Sacco 
exoneration have not succeeded. ${ }^{258}$ In 1977, however, Governor Michael Dukakis issued a controversial ${ }^{259}$ proclamation declaring August 23, the fiftieth anniversary of the executions, as "Nicola Sacco and Bartolomeo Vanzetti Memorial Day." Although it stopped short of asserting the innocence of the two men, the proclamation did describe the atmosphere of the trials and appeals as "permeated by prejudice against foreigners and hostility toward unorthodox political views" and declared "that any stigma and disgrace should be forever removed from the names of ... Sacco and ... Vanzetti, from the names of their families and descendants, and so, from the name of the Commonwealth of Massachusetts. ${ }^{260}$

Comment: Despite the absence of official exoneration, the record appears to support the judgment that Vanzetti was factually innocent. Reason exists to suspect the same of Sacco, ${ }^{261}$ but the arguments in support of that conclusion remain sufficiently speculative that I have not included him in Table $\mathrm{C}$.

\section{Discussion}

This Part attempts to draw meaning from the cases described in Part III. Although space does not permit a comprehensive analysis, I shall comment on some of the principal features of the data.

and Vanzetti: An Exchange, N.Y. REv. OF Books, May 29, 1986, at 52, 55.

258 An effort failed in 1959 to get the Massachusetts legislature to grant a posthumous pardon to Sacco and Vanzetti. RUSSELL, supra note 235, at 185.

259 For example, "[t]he state Senate . . . bitterly debated a stinging resolution attacking the proclamation as politically motivated." Stacy Jolna, Massachusetts Largely Ignores Sacco-Vanzetti, WASH. POST, Aug. 24, 1977, at A4. The resolution (Senate, No. 1836), which criticized the Governor, inter alia, for exceeding his legal authority and for having "no apparent thought for the murdered victims and their families and descendants," was never brought to a vote. Bedau \& Radelet, supra note 1 , at 74 n.274.

260 The Proclamation is published as an attachment to REPORT TO THE GOVERNOR IN THE MATTER OF SACCO AND VANZETTI, supra note 235. In a further expression of executive sympathy for the two men, in 1997, Acting Governor Paul Celluci, together with the Mayor of Boston, attended an unveiling of a sculpture commemorating Sacco and Vanzetti installed at the Boston Public Library. Photograph, An Immigrant Tribute, BOSTON GloBE, Aug. 24, 1997, at B7. The object's creator had twice before, in 1937 and 1947, offered the memorial to Massachusetts Governors who refused it. Robert D'Attilio, Chronology of the Sacco-Vanzetti Case, in SACCo-VAnzetTI: Developments AND RECONSIDERATIONS 109 (1982); Editorial, Sacco, Vanzetti Skepticism, BosTon HERALD, Aug. 21, 1997, at 28 (criticizing Mayor for accepting the sculpture).

261 The argument for Sacco's innocence rests on the theory that police fraudulently substituted a bullet later fired from Sacco's revolver for the fatal bullet removed at the autopsy from Berardelli's body. See generally YounG \& KAISER, supra note 235, at 85122. As one reviewer has said, that theory, although unproved, "is consistent with the testimony of witnesses and the autopsy, while the theory [presented by the prosecution at trial] is inconsistent." Avrich, supra note 235. See also Dorothy Gallagher, The Next-toLast Word, The NAtion, Aug. 2, 1986, at 87 (finding the bullet substitution theory "persuasive"). 


\section{A. Number of Cases Found}

Part III describes thirty-three cases in which innocent men and women were convicted of serious crimes. Six of the thirty-three were exonerated through DNA evidence. The fact that I was able to identify only thirty-three cases over the past 200 years should not be taken to mean that other such cases do not exist. Two considerations suggest that the true number of wrongful convictions is much higher. First, because local newspaper indices are not available for earlier periods, newspaper reports of relevant cases dating back more than twenty years are difficult to find. ${ }^{262}$ Second, only a fraction of wrongfully convicted prisoners can likely overcome the daunting obstacles they face to proving their innocence. In that effort, success often depends on the prisoner's good fortune as much as anything else. ${ }^{263}$

As an example of the obstacles to exoneration, consider those affecting prisoners seeking post-conviction DNA or other forensic testing. Prisoners lack the rights to the assistance of counsel, to funds for help in locating the evidence to be tested, to access to the evidence for the purpose of testing, and to funds to pay for testing. ${ }^{264}$ Prosecutors have the ability to ease the impact of these obstacles

262 For example, published indices or electronically searchable full text databases for the Boston Globe go back to 1983, and for the Boston Herald to 1991.

${ }^{263}$ For example, a number of the prisoners owed their exoneration to the true perpetrator's decision to confess, to spontaneous recantations by perjuring witnesses, or to the appearance of new witnesses in response to post-conviction publicity. In the Salvati case, supra text accompanying note 169 , innocence was shown only because of the extraordinary pro bono service of attorney Victor Garo, the interest and dedication of television newscaster Dan Rea, and disclosure of FBI documents ordered in a separate proceeding by a federal judge. Like the Salvati Four, Donnell Johnson, supra text accompanying note 69 , and Christopher Harding, supra text accompanying note 124, benefited from the happenstance of subsequent federal investigations into related matters. And Angel Hernandez, supra text accompanying note 67, won exoneration because of his attorney's persistent pro bono service and because the physical evidence in his case, after fourteen years, had not been lost or destroyed.

In other jurisdictions, many innocent death row inmates have won exoneration by sheer luck. See, e.g., the case of Anthony Porter of Illinois, whose innocence was discovered by journalism students at Northwestern University after Porter, two days before his scheduled execution, won a U.S. Supreme Court stay because of his mental retardation. Pam Belluck, Class of Sleuths to Rescue on Death Row, N.Y. TIMES, Feb. 5, 1999, at 16. In 2002, a Rhode Island prisoner was exonerated of a murder conviction by the real killer's spontaneous confession. Cathleen F. Crowley, Hormoff Gets First Taste of Freedom, Providence J., Nov. 7, 2002. And in New York, the rape convictions of five Harlem teenagers in the Central Park jogger case were called into question by the conscience-driven confession of the actual perpetrator. Jim Dwyer, Likely U-Turn by Prosecutors in 1989 Attack, N.Y. TIMES, Oct. 12, 2002.

${ }^{264}$ Massachusetts law only gives discretion to the court, on motion for a new trial, to appoint counsel and to order the payment of funds for investigation and/or testing. Mass. R. Crim. P. 30(c)(5) and Reporter's notes. Most other states have sought to ease the 
and frequently do. But the absence of any legal entitlement to post-conviction testing in appropriate cases, and the lack of uniform prosecutorial policies, leaves prisoners at the mercy of the District Attorney's willingness to cooperate in each case. ${ }^{265}$ In addition, the absence of any requirement that physical evidence be preserved for the duration of a prisoner's incarceration results, very often, in the loss or destruction of potentially exonerating evidence. ${ }^{266}$ Prisoners who cannot rely on forensic testing to prove their innocence face comparable or greater obstacles to exoneration. ${ }^{267}$

For these reasons, we can never know the number of false positives produced by the criminal justice system. Scholars who have attempted to estimate the percentage of convictions involving innocent defendants have arrived at percentages ranging from $0.5 \%$ to $4 \% .{ }^{268}$ Taking the most conservative figure, if only $0.5 \%$ of the felony convictions in Massachusetts involved factually innocent defendants, the number in FY 2000 alone would have been ninety-four. ${ }^{269}$ If, instead of considering all felony convictions, we took only those who were convicted of the most serious felonies and sent to state prison, the figure would be

prisoner's path to post-conviction testing by passing Innocence Protection Acts. See infra text accompanying note 318 .

${ }^{265}$ See generally Karen Christian, "And the DNA Shall Set You Free:" Issues Surrounding Postconviction DNA Evidence and the Pursuit of Innocence, 62 OHo ST. L.J. 1195, 1208-09 (2001); Judith A. Goldberg \& David M. Siegel, The Ethical Obligations of Prosecutors in Cases Involving Postconviction Claims of Innocence, 38 CAL. W.L. REv. 389 (2002).

266 The directors of the Cardozo Innocence Project estimate that seventy-five percent of their cases are closed because the evidence has been lost or destroyed. Email from Huy Dao, Assistant Director, Cardozo Innocence Project (Aug. 23, 2002) (on file with author). Massachusetts Superior Court Rule 14 permits court clerks to destroy or discard trial exhibits, after notice to the party that presented the exhibit, three years after the trial or hearing at which they were used. In practice, Massachusetts Superior Court clerks follow disparate preservation practices in different counties. See New England Innocence Project, Preservation of Evidence in Superior Courts - by County (2001) (unpublished, on file with author).

267 In such cases, prisoners must typically find the means to reinvestigate the case. Even if reinvestigation produces recantations from key witnesses, exoneration is far from likely. See, e.g., Ellison case, supra text accompanying note 116 (the trial court denied defendant's motion for new trial despite recantations by the two principal witnesses against her). In Massachusetts, a motion for new trial based upon evidence of recantation by prosecution witnesses "rests in the sound judicial discretion of the trial judge." Commonwealth v. Robertson, 357 Mass. 559, 562 (1970) (quoting Commonwealth v. Chin Kee, 283 Mass. 248, 256-57 (1933)).

266 See Givelber, supra note 1, at 1342-44 (discussing studies by American and English scholars).

269 Massachusetts Sentencing Commission, Survey of Sentencing Practices - FY 2000, at 13 (Table 9) (2001), available at http://www.state.ma.us/courts/admin/sentcomm/surveysentpractices.pdf (18,858 of the defendants convicted in FY 2000 were convicted of felonies). 
ten innocent prisoners each year for the last ten years. ${ }^{270}$

Regardless of the likely rate of wrongful convictions in Massachusetts, we can profit by examining the known miscarriage cases in search of systemic practices that contributed to their occurrence. Although we have identified only a small number of such cases, analysis reveals patterns that resemble those found in larger samples. ${ }^{271}$

\section{B. Innocence in Capital Cases}

It has been convincingly argued that, as a general matter, wrongful convictions occur disproportionately often in capital cases. ${ }^{272}$ The Massachusetts data support that generalization. As Table 1, below, shows, over half (eighteen out of thirtythree) of the wrongful convictions identified above were for first-degree murder, a crime punishable during most of the years covered by this study by death. ${ }^{273}$ The exoneration of three of those eighteen murderers was undiputed. Four of the eighteen, all described in Table $\mathrm{C}$, were executed. This history strongly suggests that if capital punishment is reinstated in the Commonwealth, it will at some point be applied to innocent persons.

\section{Table 1}

\section{Convictions in Capital Crimes}

\begin{tabular}{|l|c|c|c|c|}
\hline & Table A & Table B & Table C & Total \\
\hline First Degree Murder & 3 & 9 & 6 & 18 \\
\hline All other Crimes & 12 & 3 & - & 15 \\
\hline Total & 15 & 12 & 6 & 33 \\
\hline
\end{tabular}

270 See Massachusetts Department of Corrections, Court Commitments to the MASSACHUSETTS DEPARTMENT OF CORRECTIONS (1991-2000) (a total of 19,997 state prison commitments occurred during 1991-2000).

271 See infra text accompanying note 281 (discussing high proportion of mistaken eyewitness identification problems in Massachusetts and national samples). For national studies that attempt to identify the causal factors associated with wrongful convictions, see supra note 1 .

${ }^{272}$ Gross, Risks, supra note 1.

${ }^{273}$ But see discussion supra note 174. 
C. Actual Punishment Received

\section{Table 2}

Defendants' Actual Punishment ${ }^{274}$

\begin{tabular}{|l|c|c|c|c|}
\hline & Table A & Table B & Table C & Total \\
\hline I. Released from Prison & & & & \\
\hline After serving 0-12 mos. & 6 & & & 6 \\
\hline After serving 1-5 years & 4 & 3 & & 7 \\
\hline After serving 6-10 years & 3 & 2 & & 5 \\
\hline After serving 11-15 years & 2 & 3 & & 5 \\
\hline After serving 16 years or more & & 4 & & 4 \\
\hline II. Not Released from Prison & & & & \\
\hline Died in prison & & & 2 & 2 \\
\hline Executed & & & 4 & 4 \\
\hline Total & & & & 33 \\
\hline
\end{tabular}

Table 2 shows the actual punishment received by each person in Tables A, B, and C. Although six of the fifteen officially exonerated persons (Table A) were released before the end of one year in prison, the last of those "prompt" exonerations occurred in 1935. Since then, all of the wrongfully convicted prisoners who were released (Tables A and B) served significant, often long, prison terms. The others (Table $\mathrm{C}$ ), either spent many years in prison before dying there or were executed.

274 This table is modeled on a similar table in Bedau \& Radelet, supra note 1, at 71. 
D. Procedures for Exoneration and Release

\section{Table 3}

Official Exonerations in Massachusetts 1806-2002

\begin{tabular}{|c|c|c|c|c|}
\hline $\begin{array}{c}\text { Date } \\
\text { Released }\end{array}$ & \multicolumn{3}{|c|}{ Stage or Method of Release } & Total \\
\hline & Pardon & $\begin{array}{c}\text { New Trial } \\
\text { Motion }\end{array}$ & Unknown & \\
\hline $\begin{array}{c}1800- \\
1885\end{array}$ & & & & - \\
\hline $\begin{array}{c}1886- \\
1899\end{array}$ & 2 & & & 2 \\
\hline $\begin{array}{c}1900- \\
1949\end{array}$ & 3 & 2 & 1 & 6 \\
\hline $1950-$ & 1 & & & 1 \\
1959 & & & & - \\
\hline $1960-$ & & 6 & & 6 \\
\hline 1989 & & & & 15 \\
\hline $1990-$ & & & & \\
\hline Total & & & & \\
\hline
\end{tabular}

Table 3 shows the chronological distribution of the fifteen official exonerations (Table A) and the procedures employed to win release. Notably, nine of the cases occurred between 1886 and 1960, and the remaining six from 1990 to the present, with none in the intervening three decades. ${ }^{275}$ Table 3 also reveals the decline, over time, in the use of the pardon power to free the innocent. Since 1950 , only one officially exonerated prisoner has been pardoned; the other six, including four who were exonerated since 1997 on the basis of DNA evidence, won release on motions for new trial. This decline in the use of pardons to exonerate innocent convicts mirrors a nation-wide decline in grants of clemency in capital cases. That trend is mainly thought to reflect the increased political risk of granting clemency in these "law and order" times. ${ }^{276}$

275 To some extent, this probably reflects the fact that some of the older cases are drawn from books that concentrated on cases from the late nineteenth century and the first half of the twentieth century. No books were found collecting relevant cases after 1960 . I am indebted to Gross, Loss, supra note 1, at $412-13$ for this observation.

276 See James R. Acker \& Charles S. Lanier, May God - or the Governor - Have Mercy: Executive Clemency and Executions in Modern Death-Penalty Systems, 36 CRIM L. BuLl. 200, 215 (2000); Michael A.G. Korengold et al., And Justice for Few: The Collapse of the Capital Clemency System in the United States, 20 HaMLINE L. REV. 349, 359-65 (1996). But see supra note 5 (wholesale comutation of death sentences in Illinois). I have been unable to obtain clemency statistics for Massachusetts for the period since 1973. 


\section{E. Causal Factors Associated with Wrongful Convictions}

Studies of wrongful convictions in the United States have identified causal factors that are associated with such errors. For example, Barry Scheck and his colleagues studied seventy-four cases in which post-conviction DNA testing led to exoneration. ${ }^{27}$ In eighty-one percent of the cases, one or more eyewitnesses mistakenly identified the innocent prisoner as the perpetrator. The other causal factors identified were serology inclusion (thirty-eight percent), police misconduct (fifty percent), prosecutorial misconduct (forty-five percent), defective or fraudulent science (thirty-four percent), microscopic hair comparison (thirty-five percent), bad lawyering (thirty-two percent), false witness testimony (twenty percent), informants/snitches (nineteen percent), false confessions (twenty-two percent), other forensic inclusions (seven percent), and DNA inclusions (one percent). Other studies outside of Massachusetts have identified many of the same factors. ${ }^{278}$ What light do the cases described in this paper shed on the causes of wrongful convictions in Massachusetts and on the direction of needed reforms?

Table 4 shows the causal factors that appear to have been present in the thirtythree wrongful convictions examined in this Article. Despite the small number of cases in the present study, the data reveal some of the same prominent causal factors as predominate in larger studies. In particular, the Massachusetts cases show a markedly high incidence of eyewitness error, police misconduct, and the suppression of exculpatory evidence. Thus, the practices generating these errors and abuses deserve special scrutiny.

277 See SCHECK ET AL., supra note 1, App. 2, at 261-67.

278 See, e.g., RADELET ET AL., supra note 1, at 18-19; Bedau \& Radelet, supra note 1, at 56-64; BORCHARD, supra note 12, at xiii-xviii; FRANK \& FRANK, supra note 86; Radelet et al., supra note 1; CONNORS, supra note 1 (demonstrating high frequency of eyewitness misidentification in sexual assault cases). See also The Inquiry Regarding Thomas Sophonow, available at

http://www.gov.mb.ca/justice/sophonow/recommendations/english.html (last visited Aug. 15,2002 ) (reporting on a Canadian government's commission investigating the causes of a wrongful murder conviction in Manitoba). 


\section{Table 4}

All Released Prisoners 1806-2002, Causal Factors

\begin{tabular}{|c|c|c|c|c|}
\hline & $\begin{array}{l}\text { Table A } \\
(\mathrm{N}=15)\end{array}$ & $\begin{array}{l}\text { Table B } \\
(\mathrm{N}=12)\end{array}$ & $\begin{array}{l}\text { Table C } \\
(\mathrm{N}=6)\end{array}$ & $\begin{array}{l}\text { Total } \\
(\mathrm{N}=33)\end{array}$ \\
\hline EYEWITNESS ERROR & $\begin{array}{l}\text { Andrews } \\
\text { Collins } \\
\text { Hernandez*279 } \\
\text { D. Johnson } \\
\text { Miller* } \\
\text { Mitchell* Passley } \\
\text { Sarsfield* Ward }\end{array}$ & $\begin{array}{l}\text { Cero } \\
\text { Charles* } \\
\text { Harding } \\
\text { Leaster } \\
\text { Reissfelder } \\
\text { Vaughn }\end{array}$ & $\begin{array}{l}\text { Daley } \\
\text { Halligan } \\
\text { Vanzetti }\end{array}$ & 18 \\
\hline SEROLOGY INCLUSION & $\begin{array}{l}\text { Hernandez* } \\
\text { Miller } \\
\text { Mitchell* }\end{array}$ & Waters & None & 4 \\
\hline $\begin{array}{l}\text { POLICE MISCONDUCT: } \\
11^{\text {tH }} \text { HOUR INCULPATORY } \\
\text { STATEMENTS }\end{array}$ & $\begin{array}{l}\text { Sarsfield* } \\
\text { Mitchell* }\end{array}$ & Ellison & Vanzetti & 4 \\
\hline $\begin{array}{l}\text { OTHER POLICE } \\
\text { MISCONDUCT }\end{array}$ & $\begin{array}{l}\text { D. Johnson } \\
\text { Mitcheli* }\end{array}$ & $\begin{array}{l}\text { Harding } \\
\text { Reissfelder } \\
\text { Salvati } \\
\text { Limone }\end{array}$ & $\begin{array}{l}\text { Greco } \\
\text { Tameleo } \\
\text { Vanzetti }\end{array}$ & 9 \\
\hline
\end{tabular}

ALL POLICE

MISCONDUCT

\begin{tabular}{|c|c|c|c|c|}
\hline POLICE OR & Hernandez* & Charles* & Greco & 12 \\
\hline PROSECUTORIAL & Johnson, D. & Ellison & Tameleo & \\
\hline SUPPRESSION OF & & Harding & Vanzetti & \\
\hline EXCULPATORY & & Johnson, L. & & \\
\hline \multirow[t]{3}{*}{ EVIDENCE } & & Leaster & & \\
\hline & & Limone & & \\
\hline & & Salvati & & \\
\hline OTHER PROSECUTORIAL & & & Vanzetti & 1 \\
\hline \multicolumn{5}{|l|}{ MISCONDUCT } \\
\hline DEFENSE COUNSEL & & Harding & & 2 \\
\hline ERROR & & Leaster & & \\
\hline FALSE CONFESSIONS & Rodriquez & & & 1 \\
\hline POLICE PERUURY & Mitchell* & & & 1 \\
\hline \multirow[t]{3}{*}{ VICTIM PERJURY } & Chesterman & & & 3 \\
\hline & McManus, & & & \\
\hline & O'Connell & & & \\
\hline
\end{tabular}




\begin{tabular}{lllll}
\hline & $\begin{array}{l}\text { Table A } \\
(\mathrm{N}=15)\end{array}$ & $\begin{array}{l}\text { Table B } \\
(\mathrm{N}=12)\end{array}$ & $\begin{array}{l}\text { Table C } \\
(\mathrm{N}=6)\end{array}$ & $\begin{array}{l}\text { Total } \\
(\mathrm{N}=33)\end{array}$ \\
\hline PERJURY BY & & Salvati & Greco & 5 \\
PERPETRATOR & Limone & Tameleo & \\
& & Ellison & & 1 \\
\hline $\begin{array}{l}\text { OTHER WITNESS } \\
\text { PERURY }\end{array}$ & Johnson, L. & \\
\hline JAILHOUSE SNITCH & & & \\
PERURY & Johnson, L. & O'Neil & 2 \\
\hline ALL PERJURY & & & 12 \\
\hline
\end{tabular}

\section{Eyewitness Error}

Eyewitness misidentification has contributed disproportionately to wrongful convictions in Massachusetts, just as it has elsewhere. ${ }^{280}$ Over half of our fifteen official exonerations involved mistaken eyewitness identification, as did the same proportion of the total number (thirty-three) of wrongful convictions. ${ }^{281}$ Moreover, most of the nine official exoneration cases in which misidentification occurred involved multiple mistaken eyewitnesses, including five in Collins, four in Passley, and seventeen in Andrews. ${ }^{282}$ A number of the misidentifications occurred despite the witness's good opportunity to observe the perpetrator. ${ }^{283}$ The demonstrated unreliability of eyewitness identification evidence in these cases necessarily raises doubts about the accuracy of other convictions in the Commonwealth based upon similar evidence.

The data also confirm what behavioral scientists have proven about the need for new procedural safeguards in obtaining eyewitness identifications. ${ }^{284}$ Authorities are beginning to pay attention to this need. For example, the Department of Justice recently issued guidelines for law enforcement on proper eyewitness

280 See sources cited supra note 278.

281 This percentage is lower than the eighty-one percent incidence of misidentification evidence in the SCHECK ET AL., sample. See supra note 277 . This is readily attributable to the fact that the latter sample consisted entirely of DNA exonerations, which almost uniformly involved sexual assault either as the main charge or as an aggravating factor. Email from Huy Dao, Assistant Director, Cardozo Innocence Project (Aug. 19, 2002) (on file with author). Of the six DNA exonerations in the Massachusetts sample, five involved sexual assaults, and eyewitness misidentification occurred in all five.

${ }^{282}$ See also Berrett and Molway case, discussed supra note 16 (eight witnesses mistakenly identified the defendants at trial).

283 This was true, for example, in the Charles, Miller, Mitchell, and Sarsfield sexual assault cases.

${ }^{284}$ See, e.g., Gary L. Wells et al., Eyewitness Identification Procedures: Recommendations for Lineups and Photospreads, 22 L. \& HUM. BEHAV. 603 (1998); Gary L. Wells \& Eric P. Seelau, Eyewitness Identification: Psychological Research and Legal Policy on Lineups, 1 PsYCH. PUB. POL. AND LAW 765 (1995). 
identification procedures, ${ }^{285}$ and the Attorney General of New Jersey has adopted these guidelines. ${ }^{286} \mathrm{~A}$ detailed review of the police identification procedures employed in our sample cases is beyond the scope of this Article. However, some of the procedures betray the absence of such recognized safeguards as avoiding unnecessary one-on-one show-ups, ${ }^{287}$ keeping careful records of what was said and done at photographic lineup proceedings, ${ }^{288}$ and avoiding giving confirming feedback to witnesses who identify suspects. ${ }^{289}$ This suggests that eyewitness identification procedures used currently in Massachusetts should be reviewed with an eye toward bringing about needed change.

285 National Institute of Justice, Eyewitness Evidence: A Guide For LaW ENFORCEMENT (Oct. 1999), available at http://www.ojp.usdoj.gov/nij/pubs-sum/178240.htm.

286 Attorney General Guidelines for Preparing and Conducting Photo and Live Lineup Identification Procedures (New Jersey Department of Law \& Public Safety, Apr. 18, 2001), available at

http://www.idoc.state.il.us/ccp/ccp/reports/commission_report/nj_guidelines_lineup.pdf; Gina Kolata \& Iver Peterson, New Jersey is Trying New Way for Witnesses to Say, 'It's Him,' N.Y. TIMES, July 21, 2001, at A1. See also Governor's Commission on Capital Punishment, supra note 5, at 32-40 (recommendations on eyewitness identification procedures in homicide cases).

287 Show-ups were held in the following cases: Andrews, Hernandez, Miller, Mitchell, and Sarsfield.

${ }^{288}$ From a review of the transcripts and other documents in the cases described, supra note 287 , no requirement appears to exist for electronic or manual recording of identification procedures.

${ }^{289}$ See, e.g., Gary L. Wells \& Amy L. Bradfield, "Good, You Identified the Suspect:" Feedback to Eyewitnesses Distorts Their Reports of the Witnessing Experience, $83 \mathrm{~J}$. APPLIED PSYCHOL. 360 (1998). In the Mitchell case, the victim testified that after she picked Mitchell's photograph out of a mug book, "[the detectives] said 'good" to her. Trial transcript, Mitchell, at 1/71 (on file with author). But see Commonwealth v. Vardinski, 53 Mass. App. Ct. 307, 311 (2001), rev'd on other grounds, Commonwealth v. Vardinski, 2003 Mass. Lexis 10 (stating that under "approved" pretrial identification procedures in the Commonwealth, "police officers conducting the identification procedure do not possess information about the defendant and make 'no gestures or comments concerning any set of photographs'”). The Massachusetts Appeals Court also noted that the "approved" procedures are consistent with the Department of Justice Guidelines. 53 Mass. App. Ct., at 311 n.4. In Vardinski, the police employed an "electronic mug book," in which a computerized photo imaging machine displayed photographs to the eyewitness sequentially. Experts consider sequential display of lineup images superior to simultaneous display because the former technique reduces the risk of mistaken identification. See Wells et al., supra note 284 , at 31 . 


\section{Police and Prosecutorial Misconduct}

In approximately half of the seventy-four DNA exonerations studied by Scheck et al., police and prosecutorial misconduct played a role. ${ }^{290}$ Other observers also have noted the substantial role of such misconduct in wrongful convictions ${ }^{291}$ As shown in Table 4, above, the Massachusetts cases conform to that pattern, betraying a range of official misconduct including perjury, ${ }^{292}$ obstruction of defense witnesses, ${ }^{293}$ and $\operatorname{loss}^{294}$ and suppression ${ }^{295}$ of exculpatory evidence. These lapses occurred in a context in which prosecutors have the duty to disclose certain inculpatory and exculpatory evidence to the defense before trial but must depend upon the police to gather, record, preserve, and transmit relevant evidence to them. Without adequate regulation to ensure that the police perform those duties, the innocent are especially prone to conviction. This happened, for example, in the Salvati case, in which exculpatory police reports were not given to the trial prosecutor ${ }^{296}$ It happened also in the Donnell Johnson case. ${ }^{297}$ At an initial bench trial in the Johnson case, the investigating police detective falsely denied that the defendant, when first questioned, had given an exculpatory statement. Mid-way through the subsequent jury trial, the prosecutor first

290 See SCHECK ET AL., supra note 1, App. 2, at 263 (showing police misconduct was causal factor in thirty-one of sixty-two, fifty percent, and prosecutorial misconduct was causal factor in twenty-six of sixty-two cases studied, forty-five percent).

${ }^{291}$ See, e.g., Bedau \& Radelet, supra note 1, at 56-60 (stating police and prosecutorial misconduct frequent contributors to wrongful convictions). See also Armstrong, $\mathrm{CH}$. TRIB. series, supra note 1 (discussing prosecutorial misconduct in wrongful convictions cases in Illinois and other states); Moushey, PITTSBurgh POST-GazetTE series, supra note 1 (examining misconduct of federal prosecutors).

292 See supra text accompanying notes $82-85$, regarding the Mitchell case. Although no official finding of perjury was made, the police and City of Boston settled Mitchell's civil suit for $\$ 450,000$. Given the DNA exoneration, the eleventh-hour police claim that Mitchell confessed spontaneously to having worn pink pants the previous day seems incredible. See also supra at text accompanying notes 124-131, regarding the Harding case (police supervisor falsely told the judge that police officer subpoenaed by defense was in Florida).

293 See supra text accompanying notes 124-131, the Harding case.

294 See, e.g., supra at notes 132-147, the Lawyer Johnson case (noting suppression of witness statements); supra text accompanying notes 124-131, the Harding case (reporting that police lost clothing worn by Harding on night of arrest).

295 See, e.g., supra text accompanying notes 67-68, the Hernandez case (discussing suppression of computer printout supporting defendant's alibi); supra text accompanying notes 69-75, the Donnell Johnson case (discussing suppression of Johnson's exculpatory statement); supra text accompanying notes 169-192, the Salvati case (discussing suppression of informant reports).

296 See supra text accompanying note 177 . See also supra text accompanying notes 67 68 , the Hernandez case (exculpatory police computer printout suppressed, but unclear whether trial prosecutor knew of it).

297 See supra text accompanying note 69. 
received a written police report of Johnson's statement and disclosed it to the defense. ${ }^{298}$ Both the Salvati and Johnson cases illustrate the harm that can flow from the prosecutor's lack of access to a full record of the police investigation.

This lack of prosecutorial access lends itself not only to police suppression of exculpatory evidence but to delayed police production of new inculpatory evidence. The ability of police to control the timing of recording and revealing evidence makes it easier for police, if they wish, to rescue a weak prosecution case at the eleventh hour by fabricating inculpatory evidence. This appears to have been the fate of Marvin Mitchell, ${ }^{299}$ whose conviction rested in part on evidence of his alleged admission to the police that he had worn pink pants on the day of the crime. Police witnesses conceded that they had neither included this devastating admission in their contemporaneous reports, nor informed the prosecutor of it until fifteen months after the statement was purportedly made..$^{300}$ Suspicious eleventh hour revelations of previously unrevealed inculpatory evidence also occurred in the Sarsfield ${ }^{301}$ Ellison, ${ }^{302}$ and Vanzetti ${ }^{303}$ cases. If this occurred in four of our thirty-three cases, one must wonder how often thesame practice has contributed to wrongful convictions of which we remain ignorant.

Without full and timely access to relevant evidence in police hands, prosecutors cannot meet their obligations to defense counsel under the Brady doctrine, requiring disclosure of exculpatory evidence, and local discovery rules $3^{304}$ As a

298 The detective, who was later disciplined, reportedly claimed that he had turned over his entire file, which should have included the report, to the prosecutor. FLYNN, supra note 69 , at 131 . The detective's lawyer later blamed inadvertence for the detective's delay in handing over the report. Steven Wilmsen, Detective Defends Role in Wrongful Conviction, Boston GloBe, Apr. 20, 2002, at B4.

299 See supra text accompanying notes 82-85.

${ }^{300}$ Mitchell, 130 F. Supp. 2d, at 206-08; Trial transcript vol. 1, Mitchell, 130 F. Supp. at 128-48 (voir dire testimony of Det. Trent Holland). Detective Holland, who testified that he had heard Mitchell's admission while booking him at the police station, left blank the space in his police arrest report for "statements of perpetrator."

${ }^{301}$ See supra text accompanying note 93.

302 See supra text accompanying note 117.

${ }^{303}$ Eleven months after the crime, police reported for the first time that Sacco and Vanzetti had reached for their guns when they were arrested. See Young \& KaISER, supra note 235, at 67-70 ("The statements of [the arresting officers] . . represented a desperate last-minute attempt by the prosecution to beef up its case.").

${ }^{304}$ See Kyles v. Whitley, 514 U.S. 419,438 (1995) (stating that prosecutor has duty to learn of exculpatory evidence known to the police); Stanley Z. Fisher, The Prosecutor's Ethical Duty to Seek Exculpatory Evidence in Police Hands: Lessons from England, 68 FORDHAM L. REV. 1379 (2000) (discussing models for enforcing prosecution access to police records in English law and in local rules for the United States District Court for the District of Massachusetts). See also Governor's Committee on Capital Punishment, supra note 5, at 22 (urging adoption of English-style reforms to ensure prosecutorial access to police investigation records), 38 (police should electronically record witness interviews), 39 (police should videotape lineup procedures), and 120 (police and others should record 
result, fairness and accuracy in criminal adjudication must suffer. The Massachusetts wrongful conviction cases reveal the need for improvements in police investigative record-keeping and police-prosecutor communication. This suggests the wisdom of considering models for reform found in the laws of other jurisdictions. ${ }^{305}$

\section{F. Post-Exoneration Compensation and Other Relief}

Table 5

Compensation

\begin{tabular}{|c|c|c|c|c|}
\hline \multirow[t]{2}{*}{ Case Category } & \multirow[t]{2}{*}{$\begin{array}{c}\text { Total } \\
\text { Prisoners }\end{array}$} & \multicolumn{2}{|c|}{$\begin{array}{c}\text { Prisoners } \\
\text { Who Were } \\
\text { Compensated }\end{array}$} & \multirow[t]{2}{*}{$\begin{array}{c}\text { Total } \\
\text { Compensated }\end{array}$} \\
\hline & & Legis. & $\begin{array}{l}\text { Civil } \\
\text { Suit }\end{array}$ & \\
\hline $\begin{array}{l}\text { Table A: Released Prisoners: } \\
\text { Undisputed Factual } \\
\text { Innocence } \\
\text { ("Official Exonerations") }\end{array}$ & 15 & $2^{306}$ & $1^{307}$ & 3 \\
\hline $\begin{array}{l}\text { Table B: Not Officially } \\
\text { Exonerated, but Convictions } \\
\text { Vacated under } \\
\text { Circumstances Raising } \\
\text { Strong Doubts About } \\
\text { Factual Guilt }\end{array}$ & 12 & $1^{308}$ & $1^{309}$ & 2 \\
\hline $\begin{array}{l}\text { Table C: Not Officially } \\
\text { Exonerated, nor Convictions } \\
\text { Vacated, but Strong Doubts } \\
\text { About Factual Guilt }\end{array}$ & $\overline{6}$ & 0 & $0^{310}$ & 0 \\
\hline Total Cases & 33 & 3 & 2 & 5 \\
\hline
\end{tabular}

discussions regarding benefits to witnesses).

305 See Governor's Committee on Capital Punishment, supra note 5.

306 The legislature compensated Usher and Rodriquez. Unsuccessful efforts were made to obtain compensation for Chance and Collins. A private bill is pending to compensate Miller.

${ }^{307}$ Mitchell received a civil suit settlement. A civil suit is pending on behalf of Donnell Johnson.

${ }^{308}$ The legislature compensated Leaster. Efforts to obtain compensation for Lawyer Johnson, Reissfelder, and Vaughn failed.

${ }^{309}$ Harding settled his civil suit favorably. Civil suits are pending on behalf of Salvati and Limone.

${ }^{310}$ Civil suits are pending on behalf of Greco and Tameleo. 
Although some of the wrongfully convicted persons identified in this study were released after only a few weeks or months of imprisonment, some spent many years in confinement. Intuitively, one would expect such persons to be compensated for the wrongs they suffered. Yet, as Table 5 reveals, only a small fraction (five out of thirty-three) have so far received compensation: three of the fifteen prisoners who were officially exonerated (Table A), two of the twelve prisoners whose convictions were vacated because of strong doubts about factual guilt (Table B), and none of the prisoners whose convictions were not vacated (Table C).

The absence in Massachusetts of any statute authorizing state compensation for wrongfully convicted prisoners ${ }^{311}$ leaves those who seek compensation with two options, neither of which is very promising. If the prisoner can prove that the prosecuting authorities convicted him by violating state and/or federal civil rights laws, he might be able to sue successfully for damages. ${ }^{312}$ Two exonerated prisoners in our sample have won substantial settlements in civil rights suits and several more have either brought pending suits or will likely do so in the future. However, these statutes impose strict substantive, procedural and practical requirements, which few exonerated prisoners can meet. ${ }^{313}$ Those who cannot

311 Ironically, a Massachusetts statute does allow a court to order compensation for the excessive pretrial confinement of indicted persons who were finally acquitted or discharged without trial. See MASS. GEN. LAwS ch. 277, $\S 73$ (2002). This statute does not apply to wrongfully convicted persons. I am indebted to Boston attorney Robert Sinsheimer for bringing this statute to my attention. See also Ehrmann, supra note 106 (citing Berrett and Molway Seek Ely Aid on Compensation, Boston Evening Globe, Mar. 1, 1934, at 1). Ehrmann discusses the prosecution of Louis Berrett and Clement Molway in Massachusetts in 1934. Eight eyewitnesses identified Berrett and Molway as the men who murdered the victim. "Just prior to the final arguments at their trial, the actual killers confessed." The defendants were freed and granted compensation. Ehrman, supra note 106, at 44.

312 See, e.g., the case of Marvin Mitchell, supra text accompanying note 82. Mitchell sued the City of Boston and two Boston police officers, alleging violations of federal and state civil rights law and state common law. He claimed that the individual defendants conspired to convict him with fabricated evidence and perjured testimony and that the City tolerated a pattern or practice of such police misconduct. See Mitchell, 130 F. Supp. 2d 201.

${ }^{313}$ For example, to recover under the federal Civil Rights Act, 42 U.S.C. $\$ 1983$ (2000), the plaintiff must show that his conviction or sentence was obtained by violation of his constitutional rights and that it was "reversed on direct appeal, expunged by executive order, declared invalid by a state tribunal . . . or called into question by a federal court's issuance of a writ of habeas corpus ...." Heck v. Humphrey, 512 U.S. 477, 487 (1994). The plaintiff will often be defeated by the absolute immunity enjoyed by prosecutors, and for their trial testimony, even if perjured - by police officers. See Malloy v. Briggs, 475 U.S. 335, 340 (1986); Briscoe v. LaHue, 460 U.S. 325, 326 (1983). With regard to other types of police misconduct, the doctrine of qualified immunity requires plaintiff to prove that a reasonable official would have known that his conduct violated a "clearly established" constitutional right. The Supreme Court has construed the latter requirement strictly. See Wilson v. Layne, 526 U.S. 603, 616 (1999) (stating that a plaintiff needs to 
must persuade the legislature to pass a private compensation bill. In the thirtythree cases described above, the legislature has compensated only three prisoners in total and none since 1985. In comparison to administrative and judicial proceedings, the private bill mechanism lacks uniform standards and procedures for deciding claims. It is, therefore, prone to arbitrary and uneven application. ${ }^{314}$

Scholars have argued persuasively that wrongfully convicted prisoners should have a right to state compensation, even when the authorities have acted blamelessly. ${ }^{315}$ Massachusetts should follow the lead of states that have adopted compensation statutes. ${ }^{316}$ The Commonwealth should also recognize that exonerated prisoners need and deserve other services designed to restore them to productive lives in the community, such as housing, education, employment, and counseling. ${ }^{317}$

\section{G. The Need For An Innocence Protection Act}

As stated previously, prisoners seeking post-conviction exoneration through DNA or other scientific testing face daunting obstacles. In recent years, a majority of states have adopted ameliorative legislation. ${ }^{318}$ Typically, such legislation defines the conditions and procedures under which prisoners may obtain post-conviction access to evidence for testing purposes. Statutes address a range of issues, including funds for testing, access to counsel, discovery,

show either "cases of controlling authority in their jurisdiction at the time of the incident which clearly established the rule on which they seek to rely," or "a consensus of cases of persuasive authority such that a reasonable officer could not have believed that his actions were lawful").

${ }^{314}$ Adele Bernhard, When Justice Fails: Indemnification for Unjust Conviction, 6 U. CHI. L. SCH. RoundTABLE 73, 93-97 (1999).

${ }_{315}$ See, e.g., id. at 86-101; John J. Johnston, Reasonover v. Washington: Toward A Just Treatment of the Wrongly Convicted in Missouri, 68 U.M.K.C. L. REv. 411 (2000).

${ }^{316}$ See Bernhard, supra note 314, at n.1 (citing indemnification statutes in sixteen American jurisdictions). See also H.R. 4167, 104th Cong. 4167 (1999), Title III $\S 302$ (a)(3); S. 2073, 104th Cong., Title III § 302 (a)(3) (requiring states to provide for award of "reasonable damages" to exonerated persons who were sentenced to death).

317 See Northeastern University School of Law Community Lawyering Project, New England Innocence Project, Post-Exoneration Experience of Wrongfully Convicted Individuals (April 2002) (unpublished, on file with author); Illinois Criminal Justice Information Authority (2002), available at

http://www.idoc.state.il.us/ccp/ccp/technicalappendix/section_1/d_wrongfully_ convicted.pdf.

${ }^{318}$ See Kathy Swedlow, Don't Believe Everything You Read: A Review of Modern "Post-Conviction" DNA Testing Statutes, 38 CAL. W.L. REV. 355 (2002); Goldberg \& Siegel, supra note 265, at 396-98. Similar legislation is pending in the United States Congress. See supra note 316. See also Mike Dorning, 230 in House Back Bill to Reform Death Penalty, Boston GloBE, May 16, 2002, at A2; Juliet Eilperin, Death Row Legislation Gains Support on Hill, WASH. POST, July 22, 2002, at A2; Andrew Miga, Delahunt Forwards Death Penalty Reform, Boston HeRALD, June 24, 2002, at 6. 
preservation of evidence, and standards for relief. ${ }^{319}$ Enactment of such a statute in Massachusetts would give needed guidance to prisoners, counsel, and the courts.

Some foreign jurisdictions, including England and Scotland, have gone further by establishing government-financed, independent "innocence commissions" to receive and investigate all claims of innocence by convicted persons ${ }^{320}$ Thus far, no American jurisdiction has followed suit.

\section{H. The Need For Official Commissions of Inquiry}

Wrongful convictions are tragic events. Like other such events, they raise urgent questions: Why did the justice system fail? How, if at all, might the error have been avoided? How can we prevent a recurrence? In pursuit of answers, some jurisdictions have responded to particular miscarriages of justice by establishing commissions of inquiry. ${ }^{321}$ For example, after thirteen death row exonerations in Illinois, Governor George Ryan apponted a commission to study, inter alia, the causes of the wrongful convictions in those cases. In 2002, the Commission's final report recommended a number of changes in state criminal law and procedure. ${ }^{322}$ Similar commissions have sat to investigate the causes of miscarriages of justice in Canada ${ }^{323}$ and the United Kingdom ${ }^{324}$ and have

319 Swedlow, supra note 318.

320 See Lissa Griffin, The Correction of Wrongful Convictions: A Comparative Perspective, 16 AM. U. INT'L L. REV. 1241 (2001) (describing English Criminal Cases Review Commission); Peter Duff, Criminal Cases Review Commissions and "Deference" to the Courts: The Evaluation of Evidence and Evidentiary Rules, 2001 CRIM. L.R. 341 (commenting on English and Scottish commissions).

321 See generally Findley, supra note 11.

322 Governor's Committee on Capital Punishment, supra note 5 (recommending changes, inter alia, in police investigation and record-keeping, eyewitness identification procedures, disclosure of exculpatory evidence, and in procedures governing the use of jailhouse informants).

${ }^{323}$ See The Inquiry Regarding Thomas Sophonow, supra note 278; Hon. Fred Kaufman, COMmission on PRoceedings InVOLVING GUY PAUL MORIN (Ontario Ministry of Att'y Gen. 2000), available at

http:/www.attorney general.jus.gov.on.ca/html/morin/morin.htm. Compare NATIONAL COMMISSION ON LAW OBSERVANCE AND ENFORCEMENT, JURISDICTION REPORT ON LAWLESSNESS IN LAW ENFORCEMENT (1931) (report on abusive law enforcement practices nationwide); LOS ANGELES POLICE DEPARTMENT, BOARD OF INQUIRY INTO THE RAMPART CORRUPTION INCIDENT, FINAL REPORT, available at

http://www.lapdonline.org/whats_new/boi/boi_exec_summary.htm (last visited Jan. 23, 2002) (inquiry into remedies for scandal in which, inter alia, Los Angeles police framed innocent defendants), criticized in Edwin Chemerinsky, An Independent Analysis of the Los Angeles Police Department's Board of Inquiry Report on the Rampart Scandal, 34 LoYOLA L.A. L. REV. 545 (2001). For accounts of the Rampart scandal itself, see, e.g., Ann W. O'Neill, Ex-Prosecutor Defends Actions in Rampart Case, L.A. TIMES, Oct. 18, 2000, at B1; Scott Glover \& Matt Lait, Detective Under Scrutiny in More Cases, L.A. TIMES, Dec. 
recommended appropriate reforms. The ongoing Congressional hearings into the conduct of the FBI in the Salvati Four case also follow this approach ${ }^{325}$ Every state, including Massachusetts, should follow these examples.

\section{CONCLUSION}

The conviction and punishment of innocent persons in Massachusetts cannot be regarded as a freakish rarity or a matter of only historical interest. This Article has identified a number of individuals who have suffered that fate. Others undoubtedly exist and still more will certainly join their ranks. As Scheck et al., noted, "[w] hat matters most is not how these people got out of jail, but how they got into it." ${ }^{326}$ The study of wrongful convictions sheds light upon the causes of error and underscores the need for reform. The present effort is no substitute for inquiries by official commissions, which I have urged. But the data presented here do indicate that, in Massachusetts, eyewitness misidentification and suppression of exculpatory evidence by police and prosecutors have contributed disproportionately to the conviction of innocent persons. This suggests the need to review eyewitness identification procedures, as well as police procedures for recording, preserving, and transmitting evidence to prosecutors. The data also suggest the inadequacy of present arrangements for compensating innocent, exonerated prisoners. Finally, Massachusetts lawmakers should address the plight of prisoners who seek post-conviction forensic testing by adopting an Innocence Protection Act. Addressing wrongful convictions in these ways would not eliminate the problem entirely but could be expected to reduce the number of innocent persons who are convicted and imprisoned.

19, 2000, at B1; Scott Glover \& Matt Lait, Murder Case Derailed by Rampart Link, L.A. TIMES, Aug. 10, 2000, at A1; Lynn Smith, New Wealth in Rampart's Red Glare, L.A. Times, Mar. 18, 2001, at E1. Compare also CoMmission to Investigate Allegations of Police Corruption and the ANTI-CORRuption Procedures of the POLICE DEPARTMENT 39 (1994) (inquiry into convictions obtained as a result of testimony provided by corrupt police officers).

324 See MisCARriages OF JuSTICE: A REVIEW OF JUSTICE IN ERROR 45 (Clive Walker \& Keir Starmer eds., 1999) (discussing the work of a number of official commissions appointed either to inquire into particular wrongful convictions or prompted by the occurrence of same). The British miscarriage cases that prompted authorities to appoint commissions of inquiry include: Confait -ROYal COMMISSION ON CRIMINAL Procedure, PHILIPS REPORT, 1981, Cmnd. 8092; Dougherty and Virag - REPORT TO THE SECRETARY OF

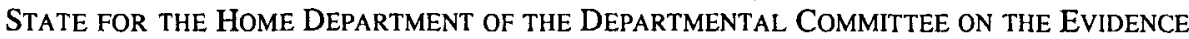
of IdENTIFICATION IN CRIMINAL CASES, THE DEVlin REPORT (1976)); and the Guildford Four and Maguire Seven - May Inquiry Reports 1989, 90 HC 556; 1992-93 HC 296. See also Royal Commission on CRIMinal JuSTICE, THE RunCIMAN REPORT, 1993, Cmnd 2263.

325 See supra text accompanying note 169.

326 SCHECK ET AL., supra note 1, at XX. 